\title{
Synthesis, Properties, and Some Rhodium, Iridium, and Platinum Complexes of a Series of Bulky $m$-Terphenylphosphine Ligands
}

Laura Ortega-Moreno, María Fernández-Espada, Juan J. Moreno, Carlos Navarro-Gilabert, Jesús Campos, Salvador Conejero, Joaquín López-Serrano, Celia Maya, Riccardo Peloso,* Ernesto Carmona*

Instituto de Investigaciones Químicas (IIQ), Departamento de Química Inorgánica and Centro de Innovación en Química Avanzada (ORFEO-CINQA). Universidad de Sevilla and Consejo Superior de Investigaciones Científicas (CSIC). Avenida Américo Vespucio 49, 41092 Sevilla (Spain) Fax: (+34) 954460565

E-mail: guzman@us.es, rpeloso@us.es

\begin{abstract}
.
A series of sterically demanding aryl phosphine ligands $(\mathbf{L})$ bearing terphenyl substituents, $\mathrm{PR}_{2} \mathrm{Ar}$ ' $(\mathrm{R}=$ hydrocarbyl, Ar' = 2,6-diarylphenyl radical) has been prepared and characterized. The stability of these ligands towards oxidation in the air has been tested, and theoretical and experimental studies aimed to provide information on their electronic and steric properties have been performed. Treatment of the metal dimers $[\mathrm{MCl}(\mathrm{COD})]_{2}(\mathrm{M}=\mathrm{Rh}, \mathrm{Ir}$; $\mathrm{COD}=1,5$ cyclooctadiene) with ligands $\mathrm{PMe}_{2} \mathrm{Ar}^{\mathrm{Xyl}_{2}}(\mathbf{L 1})$ and $\mathrm{PMe}_{2} \mathrm{Ar}^{\mathrm{Dipp}_{2}}(\mathbf{L 5})$, in a 1:1 metal:ligand ratio, afforded the expected square-planar 16-electron complexes $\left[\mathrm{MCl}(\mathrm{COD})\left(\mathrm{PMe}_{2} \mathrm{Ar}^{\mathrm{Xyl}}{ }_{2}\right)\right]$ and $\left[\mathrm{MCl}(\mathrm{COD})\left(\mathrm{PMe}_{2} \mathrm{Ar}^{\mathrm{Dipp}_{2}}\right)\right]$, respectively. These compounds were readily converted into the corresponding dicarbonyl derivatives, $\left[\mathrm{MCl}(\mathrm{CO})_{2}\left(\mathrm{PMe}_{2} \mathrm{Ar}^{\mathrm{Xyl}}\right)\right]$ and $\left[\mathrm{MCl}(\mathrm{CO})_{2}\left(\mathrm{PMe}_{2} \mathrm{Ar}^{\mathrm{Dipp}_{2}}\right)\right]$, respectively. While the expected $\kappa^{1}-\mathrm{P}$ coordination mode of the $\mathrm{PR}_{2} \mathrm{Ar}$ ' ligands is found for these rhodium and iridium species, the mononuclear $\mathrm{Pt}(\mathrm{II})$ derivative obtained by reaction of $\mathrm{PtCl}_{2}$ with $\mathrm{PMe}_{2} \mathrm{Ar}^{\mathrm{Dipp}_{2}}$ has composition $\left[\mathrm{PtCl}_{2}\left(\mathrm{PMe}_{2} \mathrm{Ar}^{\mathrm{Dipp}}{ }_{2}\right)\right]$, and exhibits a bidentate $\kappa^{1}-\mathrm{P}, \eta^{1}-$ arene coordination mode involving one of the ipso carbon atoms of a flanking terphenyl aryl ring. The corresponding carbonyl compound $\left[\mathrm{PtCl}_{2}(\mathrm{CO})\left(\mathrm{PMe}_{2} \mathrm{Ar}^{\mathrm{Dipp}_{2}}\right)\right]$, was generated under a $\mathrm{CO}$ atmosphere and exhibits $\kappa^{1}-\mathrm{P}$ coordination mode.
\end{abstract}

\section{Introduction.}

Phosphines and related phosphorus-donor Lewis bases are one of the most widely used classes of ligands in homogenous catalysis, coordination and organometallic chemistry.[1] Their electronic and steric features can easily be modified in systematic and predictable ways,[2] allowing for the design of metal complexes with specific characteristics with regard to red-ox behaviour, solubility, electrophilicity, and other properties. In particular, the use of sterically demanding phosphines, either in their monodentate or polydentate versions, permits kinetic stabilization of low-coordinate organometallic complexes and agostic structures,[3] unusual geometries,[4] highly reactive metal-carbon bonds,[5] etc. In this context, it is worth mentioning the crucial role of a bulky pincer-type diphosphonite ligand (PONOP) in the characterization of the first $\sigma$-methane complex reported by Brookhart et al. in 2009.[6]

In recent years, bulky phosphines have promoted challenging metal-catalyzed transformations leading to the synthesis of high value products, as witnessed by outstanding contributions from the groups of Beller,[7] Buchwald,[8] Fu,[9] and Hartwig,[10] among others. As a prominent example, Buchwald-type heteroleptic dialkylbiaryl phosphines $\mathrm{PR}_{2} \mathrm{Ar}(\mathrm{Ar}=$ 
biphenyl) have found wide application in palladium catalyzed cross-coupling and carbonheteroatom bond formation.[11] Although these ligands are nowadays commercially available for an ample range of biaryl (Ar) substituents, only a restricted set of bulky alkyl $\mathrm{R}$ groups, mainly ${ }^{t} \mathrm{Bu}\left(\mathrm{CMe}_{3}\right)$ and $\mathrm{Cy}\left(\mathrm{C}_{6} \mathrm{H}_{11}\right)$, has been introduced in their molecular structures. It has been proposed that the high activity of catalytic systems that combine metal complexes with dialkylbiaryl phosphines is often to ascribe to the ability of the biaryl group to bind to the metal centre through weak so-called secondary interactions,[11b] thus stabilizing coordinatively unsaturated reaction intermediates. In consequence, similar to other aryl phosphines, biaryl- and terphenylphosphines may be viewed as hemilabile ligands[12] by virtue of $\eta^{\mathrm{n}}$-arene coordination of a pendant aryl ring.

In spite of the enormous popularity of biarylphosphines within the chemical community, information on the analogous terphenylphosphines, $\mathrm{PR}_{2} \mathrm{Ar}^{\prime}$ ( $\mathrm{Ar}{ }^{\prime}=$ terphenyl group) is rather scarce and limited to a handful of ligands and a few coordination complexes with late transition metals.[3k,13] It is, however, noteworthy that the exceptional protecting steric features of bulky terphenyl groups permitted in 2005 the isolation of the first quintuply bonded dimetal complex by Power and collaborators.[14] Our research group has recently employed these large organic radicals to generate unusual quadruply bonded dimolybdenum complexes,[15] and some terphenylphosphines to stabilize low coordinate $\mathrm{Pt}(0)$ species,[3k] and cationic digold complexes.[13e] In this contribution, we describe the synthesis and characterization of a family of bulky dialkyl terphenylphosphine ligands, together with the study of their air-stability and of some examples of coordination compounds of late transition metals. DFT calculations and experimental work have also been employed to estimate the steric bulk of these ligands and their electron-donating features.

\section{Results and discussion.}

Synthesis and spectroscopy. Ligands L1-L11 were prepared analogously to ligands L1 and L5, whose synthesis has recently been reported by our group.[3k,13d] Ordered from the least to the most steric demanding, we employed the following terphenyl groups: 2,6-diphenylphenyl $\left(\mathrm{Ar}^{\mathrm{Ph}_{2}}\right), \quad$ 2,6-bis(2,6-dimethylphenyl)phenyl $\left(\mathrm{Ar}^{\mathrm{Xyl}}\right), \quad$ 2,6-bis(2,4,6-trimethylphenyl)phenyl $\left(\mathrm{Ar}^{\mathrm{Mes}_{2}}\right)$,[13a-c] 2,6-bis(2,6-di(isopropyl)phenyl)phenyl $\left(\mathrm{Ar}^{\mathrm{Dipp}_{2}}\right), \quad$ and 2,6-bis(2,4,6tri(isopropyl)phenyl)phenyl $\left(\mathrm{Ar}^{\mathrm{Tipp}_{2}}\right)$. The procedure we propose is essentially based on that reported by Protasiewicz and collaborators[13a] but employs a terphenyl Grignard reagent instead of the analogous terphenyl lithium compound, as the source of the terphenyl fragment (Scheme 1). Moreover, the last step of the synthesis, that is the transformation of dihalo terphenylphosphines into the corresponding dihydrocarbyl terphenylphosphines, was also performed with the use of Grignard reagents in all cases. Ligands L1-L11 were isolated in moderate to high yields (based on $\mathrm{Mg}\left(\mathrm{Ar}{ }^{\prime}\right) \mathrm{Br}$ ) as fairly air-stable colourless solids. It is noteworthy that the synthetic procedure can start directly from the dihalo terphenylphosphines, $\mathrm{Ar}^{\prime} \mathrm{PX}_{2}$, which were prepared in a large scale (up to $8 \mathrm{~g}$ approximately), isolated as moisturesensitive solid mixtures of $\mathrm{Ar}^{\prime} \mathrm{PCl}_{2}, \mathrm{Ar}^{\prime} \mathrm{PClBr}$, and $\mathrm{Ar}^{\prime} \mathrm{PBr}_{2}$, and stored under a nitrogen or an argon atmosphere. 
<smiles>[R]c1cc([R])c([N+](=O)[O-])c([R])c1</smiles><smiles>[R]c1cc([R])c(-c2cccc(-c3c([R])cc([R])cc3Br)c2[R])c(Br)c1</smiles>

$\mathrm{PMe}_{2} \mathrm{Ar}^{X \mathrm{Xl}_{2}}$ (L1): R = Me, R' = H, R" = Me $\mathrm{PEt}_{2} \mathrm{Ar}^{X y l_{2}}$ (L2): R = Me, R' = H, R" = Et $\mathrm{P}\left(\mathrm{C}_{3} \mathrm{H}_{5}\right)_{2} \mathrm{Ar}^{\mathrm{Xyl} \mathrm{l}_{2}}$ (L3): $\mathrm{R}=\mathrm{Me}, \mathrm{R}^{\prime}=\mathrm{H}, \mathrm{R}^{\prime \prime}=\mathrm{CH}_{2} \mathrm{CH}=\mathrm{CH}_{2}$ $\mathrm{P}\left(\mathrm{C}_{4} \mathrm{H}_{7}\right)_{2} \mathrm{Ar}^{\mathrm{Xyl}_{2}}$ (L4): $\mathrm{R}=\mathrm{Me}, \mathrm{R}^{\prime}=\mathrm{H}, \mathrm{R}^{\prime \prime}=\mathrm{CH}_{2} \mathrm{CH}_{2} \mathrm{CH}=\mathrm{CH}_{2}$ $\mathrm{PMe}_{2} \mathrm{Ar}^{\mathrm{Dipp}_{2}}$ (L5): $\mathrm{R}={ }^{i} \mathrm{Pr}, \mathrm{R}^{\prime}=\mathrm{H}, \mathrm{R} "=\mathrm{Me}$ $\mathrm{PEt}_{2} \mathrm{Ar}^{\mathrm{Dipp}_{2}}$ (L6): $\mathrm{R}={ }^{i} \mathrm{Pr}, \mathrm{R}^{\prime}=\mathrm{H}, \mathrm{R}^{\prime \prime}=\mathrm{Et}$ $\mathrm{P}\left(\mathrm{C}_{3} \mathrm{H}_{5}\right)_{2} \mathrm{Ar}^{\mathrm{Dipp}_{2}}$ (L7): $\mathrm{R}={ }^{i} \mathrm{Pr}, \mathrm{R}^{\prime}=\mathrm{H}, \mathrm{R}^{\prime \prime}=\mathrm{CH}_{2} \mathrm{CH}=\mathrm{CH}_{2}$ $\mathrm{PMe}_{2} \mathrm{Ar}^{\mathrm{Trip}_{2}}$ (L8): $\mathrm{R}={ }^{i} \mathrm{Pr}, \mathrm{R}^{\prime}={ }^{i} \mathrm{Pr}, \mathrm{R}^{\prime \prime}=\mathrm{Me}$ $\mathrm{PEt}_{2} \mathrm{Ar}^{\mathrm{Mes}_{2}}$ (L9): $\mathrm{R}=\mathrm{Me}, \mathrm{R}^{\prime}=\mathrm{Me}, \mathrm{R}^{\prime \prime}=\mathrm{Et}$ $\mathrm{P}\left(\mathrm{C}_{2} \mathrm{H}\right)_{2} \mathrm{Ar}^{\mathrm{Mes}_{2}}$ (L10): $\mathrm{R}=\mathrm{Me}, \mathrm{R}^{\prime}=\mathrm{Me}, \mathrm{R}^{\prime \prime}=\mathrm{C} \equiv \mathrm{CH}$ $\mathrm{PMe}_{2} \mathrm{Ar}^{\mathrm{Ph}_{2}}$ (L11): $\mathrm{R}=\mathrm{H}, \mathrm{R}^{\prime}=\mathrm{H}, \mathrm{R}^{\prime \prime}=\mathrm{Me}$<smiles>[R]c1cc([R])c(-c2cccc(-c3c([R])cc([R])cc3[R])c2[R])c([R])c1</smiles>

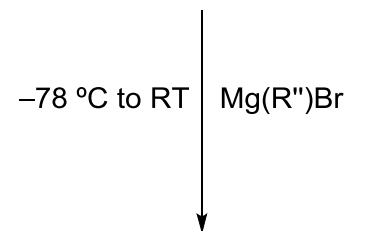<smiles>[R]c1cc([R])c(-c2cccc(-c3c([R])cc([R])cc3[R])c2[R])c([R])c1</smiles>

Scheme 1. Synthesis of ligands L1-11.

Compounds L1-L11 feature high solubility in common aprotic organic solvents such as dichloromethane, chloroform, ethers, toluene, and pentane, even at low temperatures. On the other hand, they exhibit scarce solubility in cold methanol, which was the solvent of choice for their purification. Single crystals of phosphines L7 and L10 were grown by slow evaporation of concentrated pentane solutions and analyzed by X-Ray diffraction analyses. Their molecular structures in the solid state are depicted in Figure 1. By analogy with the structures reported for other $m$-terphenylphosphines, $[13 \mathrm{~b}, 1]$ the $\mathrm{PR}_{2}$ unit is bent away from one of the lateral rings of the terphenyl substituent. This distortion reduces steric interactions and results in $\mathrm{P}-\mathrm{C}-\mathrm{C}$ angles that differ significantly. Thus, in $\mathrm{P}\left(\mathrm{C}_{3} \mathrm{H}_{5}\right)_{2} \mathrm{Ar}^{\mathrm{Dipp}_{2}}, \mathbf{L 7}$, the $\mathrm{P} 1-\mathrm{C} 6-\mathrm{C} 5$ and $\mathrm{P} 1-\mathrm{C} 6-\mathrm{C} 7$ angles are of 114.1(1) and 127.2(1) ${ }^{\circ}$, respectively, while in $\mathrm{P}\left(\mathrm{C}_{2} \mathrm{H}\right)_{2} \mathrm{Ar}^{\mathrm{Mes}_{2}}$, $\mathbf{L 1 0}$, the corresponding angles have values 111.6(2) and 128.6(2) . The bond distances from the phosphorus atom to the carbon atoms of the hydrocarbyl substituents in $\mathbf{L 7}$ are very similar (1.860(2) and 1.856(2) $\AA$, for P1-31 and P1-34, respectively). They become somewhat different in the bis(acetylide) phosphine $\mathbf{L 1 0}$, where the $\mathrm{P} 1 \mathrm{a}-\mathrm{C} 24$ bond to the acetylide oriented towards the mesityl group is slightly elongated $(1.792(4) \AA)$ relative to the P1a-C26 bond that points to the empty space between the mesityl rings (1.770(3) $\AA$ ). Probably to relieve the steric hindrance, the acetylide group above the mesityl ring (C24-C25) distorts appreciably at $\mathrm{C} 24$, with a $\mathrm{C} 25-\mathrm{C} 24-\mathrm{P} 1 \mathrm{a}$ angle of $163.5(2)^{\circ}, v s .172 .2(3)^{\circ}$ for C26-C26-P1a.
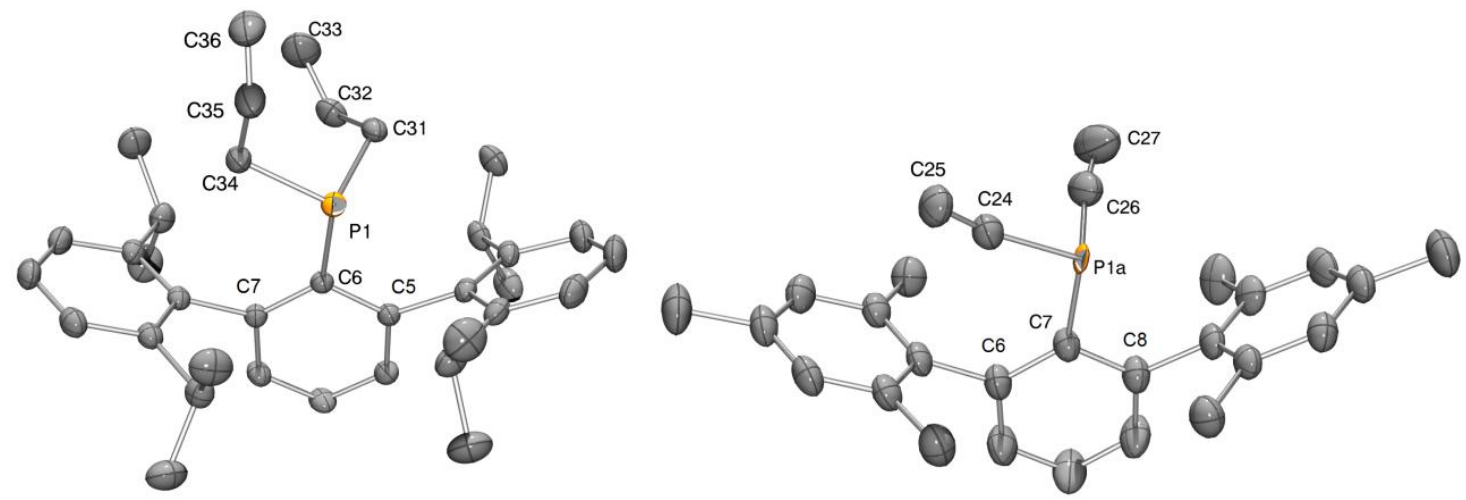

Figure 1. Ortep view of the molecular structures of ligands L7 (left) and L10 (right) (50\% probability ellipsoids) 
All of the newly reported $\mathrm{PR}_{2} \mathrm{Ar}$ ' ligands were fully characterized by elemental analysis and multinuclear NMR spectroscopy. Their solution ${ }^{1} \mathrm{H}$ NMR spectra are consistent with a high degree of apparent symmetry as a result of fast rotation around the $\mathrm{C}_{\text {aryl }} \mathrm{C}_{\text {aryl }}$ or $\mathrm{P}-\mathrm{C}_{\mathrm{Ar}}$, bonds (Scheme 2).

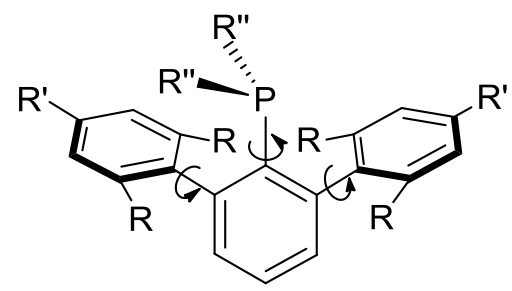

Scheme 2. Representation of the molecular structure of $\mathrm{PR}_{2} \mathrm{Ar}$ ' ligands.

${ }^{31} \mathrm{P}\left\{{ }^{1} \mathrm{H}\right\}$ NMR studies revealed that the phosphorus nucleus of ligands L1-L11 resonates in an ample frequency range, with chemical shift in the interval from -74.3 to $-8.3 \mathrm{ppm}$ (Table 1). It has long been known[16] that the phosphorus substituents have an additive effect on the ${ }^{31} \mathrm{P}$ NMR shift, with deviations in the predicted $\delta$ values usually smaller than 5-6 ppm.[16c] The four dimethylterphenylphosphines studied in this work, namely $\mathbf{L 1}\left(\operatorname{Ar}^{\mathrm{Xyl}}{ }_{2}\right), \mathbf{L 5}\left(\mathrm{Ar}^{\mathrm{Dipp}}{ }_{2}\right), \mathbf{L 8}$ $\left(\mathrm{Ar}^{\mathrm{Tipp}}{ }_{2}\right)$, and $\mathbf{L 1 1}\left(\mathrm{Ar}^{\mathrm{Ph}}{ }_{2}\right)$ feature $\delta\left({ }^{31} \mathrm{P}\right)$ in the narrow range from -41.3 to $-35.6 \mathrm{ppm}$. These $\delta$ values are close to the contribution of the two P-Me substituents ( $-21 \mathrm{ppm}$ each [16c]), albeit of somewhat smaller absolute magnitude. Ethyl substituents offer a smaller contribution of roughly $-7 \mathrm{ppm}$ each, whereas longer chain $n$-alkyl radicals have intermediate contributions of about -11 ppm.[16c] Thus, it is not unexpected that the $\mathrm{PEt}_{2} \mathrm{Ar}$ ' ligands $\mathbf{L 2}\left(\mathrm{Ar}^{\mathrm{Xyl}}{ }_{2}\right), \mathbf{L 6}\left(\mathrm{Ar}^{\mathrm{Dipp}_{2}}\right)$, and $\mathbf{L 9}\left(\mathrm{Ar}^{\mathrm{Mes}_{2}}\right)$ resonate in the vicinity of $-9 \mathrm{ppm}$, while the bis(allyl) and bis( $n$-butenyl)phosphines L3, L4, and L7, have $\delta$ values of $c a$. -17 to $-20 \mathrm{ppm}$. Finally in this regard, the bis(ethynyl)phosphine $\mathbf{L 1 0}$ resonates in the low frequency area, with $\delta-74.3 \mathrm{ppm}$, in accordance with individual ethynyl contributions of $c a .-31 \mathrm{ppm} .[16 \mathrm{c}]$ It is reasonable to ascribe this shift to the shielding anisotropic effect of the two $\mathrm{C} \equiv \mathrm{C}$ bonds directly linked to the phosphorus atom. Indeed, P-containing molecules with structure akin to $\mathbf{L 1 0}$ exhibit comparable ${ }^{31} \mathrm{P}$ chemical shift parameters.[16d] To close this discussion, it should be noted that at variance with P-bonded substituents, those on the flanking aryl rings of the terphenyl radical (two or three methyl or iso-propyl groups) do not appear to have a significant effect on the ${ }^{31} \mathrm{P}$ chemical shift value.

Table 1. ${ }^{31} \mathrm{P}$ NMR chemical shifts and yields for ligands L1-11.

\begin{tabular}{|c|c|c|}
\hline Ligand & $\begin{array}{c}{ }^{31} \mathbf{P}\left\{{ }^{1} \mathbf{H}\right\} \mathbf{N M R} \\
(\mathbf{p p m})\end{array}$ & $\begin{array}{c}\text { Yield } \\
(\boldsymbol{\%})\end{array}$ \\
\hline \hline L10 & -74.3 & 44 \\
\hline L5 & -41.3 & 57 \\
\hline L1 & -40.4 & 60 \\
\hline L8 & -40.7 & 54 \\
\hline L11 & -35.8 & 80 \\
\hline L7 & -20.0 & 60 \\
\hline L3 & -19.0 & 50 \\
\hline L4 & -17.1 & 55 \\
\hline L6 & -9.3 & 41 \\
\hline L2 & -8.0 & 40 \\
\hline L9 & -8.3 & 43 \\
\hline
\end{tabular}


The terphenylphosphine ligands discussed in this work are expected to behave as monodentate P-donor Lewis bases, although the presence of a polyaryl substituent on the phosphorus atom may provide additional bonding capabilities. As already noted, it is conceivable that they behave as hemilabile ligands, yielding tethered $\kappa^{1}-P, \eta^{n}$-arene coordination modes, as it has been amply demonstrated in the literature.[3k, 11a-b, 12b, 13b] In this regard, it is worth highlighting that the presence of unsaturated hydrocarbyl chains such as $\mathrm{C} \equiv \mathrm{CH},-\mathrm{CH}_{2} \mathrm{CH}=\mathrm{CH}_{2}$ and $-\mathrm{CH}_{2} \mathrm{CH}_{2} \mathrm{CH}=\mathrm{CH}_{2}$ in the molecular framework of the phosphines L3, L4, L7, and L10, could enable both further chemical elaboration of these functions by classical $\mathrm{C}=\mathrm{C}$ and $\mathrm{C} \equiv \mathrm{C}$ bond reactivity, and formation of $\eta^{2}$-alkyne or -alkene metal bonds in mono or polymetallic structures.

Oxidation experiments. Taking into account the potential applications of this family of ligands in organometallic synthesis and homogeneous catalysis, we considered of interest to determine their air-stability under various conditions. Barder and Buchwald analysed experimentally and theoretically the resistance of dialkylbiaryl phosphines, $\mathrm{PR}_{2} \mathrm{Ar}$, toward oxidation.[8e] As expected, they recognized a dramatic effect of both the electron density residing on the phosphorus atom upon changing the nature of the $\mathrm{R}$ substituents (e.g. $\mathrm{R}=\mathrm{Ph} v s$. Cy or $i$-Pr $v s t$ $\mathrm{Bu}$ ), and of the steric demands of the $\mathrm{R}$ radicals and the substituents at positions 2' and 6' of the biaryl backbone, on the facility of phosphine oxidation.

We have studied the reactivity toward $\mathrm{O}_{2}$ of the dimethylphosphines $\mathrm{PMe}_{2} \mathrm{Ar}^{\mathrm{Xyl}_{2}}(\mathbf{L 1})$, $\mathrm{PMe}_{2} \mathrm{Ar}^{\mathrm{Dipp}_{2}}$ (L5), $\mathrm{PMe}_{2} \mathrm{Ar}^{\mathrm{Tipp}_{2}}$ (L8), and the previously reported[13a-c] $\mathrm{PMe}_{2} \mathrm{Ar}^{\mathrm{Mes}_{2}}$. In addition, $\mathrm{PEt}_{2} \mathrm{Ar}^{\mathrm{Xyl}_{2}}(\mathbf{L 2})$ and $\mathrm{P}_{(}\left(\mathrm{C}_{3} \mathrm{H}_{5}\right)_{2} \mathrm{Ar}^{\mathrm{Xyl}_{2}}$ (L3) were also investigated. In all instances, the ligands were exposed to air as pure, finely divided powdered samples at room temperature, and also in toluene solutions, in the latter case at room temperature and at $100{ }^{\circ} \mathrm{C}$ (see Experimental Section). The degree of oxidation was ascertained from the relative intensities of the ${ }^{31} \mathrm{P}\left\{{ }^{1} \mathrm{H}\right\}$ NMR resonances due to the $\mathrm{PR}_{2} \mathrm{Ar}$ ' ligands $(\mathbf{L})$ and the corresponding phosphine oxides $(\mathbf{L} \cdot \mathbf{O})$.

In the solid state no significant oxidation was detected after 8 days at room temperature for any of the above mentioned phosphines. By contrast, a notable amount of phosphine oxide, $\mathbf{L} \cdot \mathbf{O}$, was observed after five days in toluene solution at $25^{\circ} \mathrm{C}$ for all the studied phosphines but $\mathrm{PEt}_{2} \mathrm{Ar}^{\mathrm{Xyl}}{ }_{2}$ (L2). The $\mathbf{L}: \mathbf{L} \cdot \mathbf{O}$ proportion was found to be of ca. 70:30 for $\mathrm{PMe}_{2} \mathrm{Ar}^{\mathrm{Xyl}_{2}}$ (L1) and $\mathrm{PMe}_{2} \mathrm{Ar}^{\mathrm{Mes}_{2}}$, and increased to 80:20 for $\mathrm{PMe}_{2} \mathrm{Ar}^{\mathrm{Dipp}_{2}}$ (L5) and 95:5 for $\mathrm{PMe}_{2} \mathrm{Ar}^{\mathrm{Tipp}_{2}}$ (L8). The allyl-substituted phosphine $\mathbf{L 3}$, was also prone to oxidation and gave under these conditions a ca. 2:1 mixture of $\mathbf{L}: \mathbf{L} \cdot \mathbf{O}$, while the bis(ethyl)phosphine, $\mathrm{PEt}_{2} \mathrm{Ar}^{\mathrm{Xyl}}{ }_{2}(\mathbf{L 2})$, was uncommonly stable, and remained essentially unaltered (>99:1). It is remarkable that the addition of one methyl group on the alkyl substituents from $\mathrm{PMe}_{2} \mathrm{Ar}^{\mathrm{Xyl}}{ }_{2}$ (L1) to $\mathrm{PEt}_{2} \mathrm{Ar}^{\mathrm{Xyl}}{ }_{2}(\mathbf{L 2})$ results in such a striking increase in the stability of the phosphine against air oxidation. It is, however, of note that an even more dramatic effect was observed in the comparative study of the reactivity toward $\mathrm{O}_{2}\left(100{ }^{\circ} \mathrm{C}, 65 \mathrm{~h}\right)$ of the biaryl phosphines $\mathrm{P}^{i} \mathrm{Pr}_{2} \mathrm{Ar}$ and $\mathrm{P}^{t} \mathrm{Bu}_{2} \mathrm{Ar}\left(\mathrm{Ar}=\mathrm{C}_{6} \mathrm{H}_{4}-2-\mathrm{C}_{6} \mathrm{H}_{4}\right)$, in toluene solutions, as the latter yielded only $19 \%$ of the phosphine oxide whereas the former underwent complete oxidation.[8e] At $100{ }^{\circ} \mathrm{C}$ in toluene solution all the terphenyl phosphines investigated transformed into the corresponding oxides over a period of $24 \mathrm{~h}$, with the only exception of $\mathrm{PEt}_{2} \mathrm{Ar}^{\mathrm{Xyl}}{ }_{2}$ that produced a nearly 2:1 mixture of $\mathbf{L}$ and $\mathbf{L} \cdot \mathbf{O}$. 
Coordination to $\operatorname{Rh}(\mathbf{I}), \operatorname{Ir}(\mathbf{I})$, and $\operatorname{Pt}(\mathbf{I I})$ Centres. Phosphines $\mathrm{PMe}_{2} \mathrm{Ar}^{\mathrm{Xyl}_{2}}$ (L1) and $\mathrm{PMe}_{2} \mathrm{Ar}^{\mathrm{Dipp}_{2}}(\mathbf{L 5})$ reacted cleanly $\left(\mathrm{CH}_{2} \mathrm{Cl}_{2}, 25{ }^{\circ} \mathrm{C}\right)$ with the dimer $[\mathrm{RhCl}(\mathrm{COD})]_{2}(\mathrm{COD}=1,5-$ cyclooctadiene) in a 1:1 ratio of $\mathrm{Rh}$ to phosphine to generate the air-stable yellow complexes $\mathbf{1} \cdot \mathbf{L 1}$ and $\mathbf{1} \cdot \mathbf{L 5}$, respectively, in high yield (Scheme $3 \mathrm{a}$ ). These compounds result from the foreseen cleavage of the chloride bridges of the dimer by the reacting phosphine, and feature square planar geometry, with the diene acting as a bidentate ligand. Similarly, the iridium precursor $[\operatorname{IrCl}(\mathrm{COD})]_{2}$ was converted by treatment with ligands $\mathbf{L 1}$ and $\mathbf{L 5}$ into the corresponding adducts $\mathbf{2} \cdot \mathbf{L} \mathbf{1}$ and $\mathbf{2} \cdot \mathbf{L 5}$, respectively.

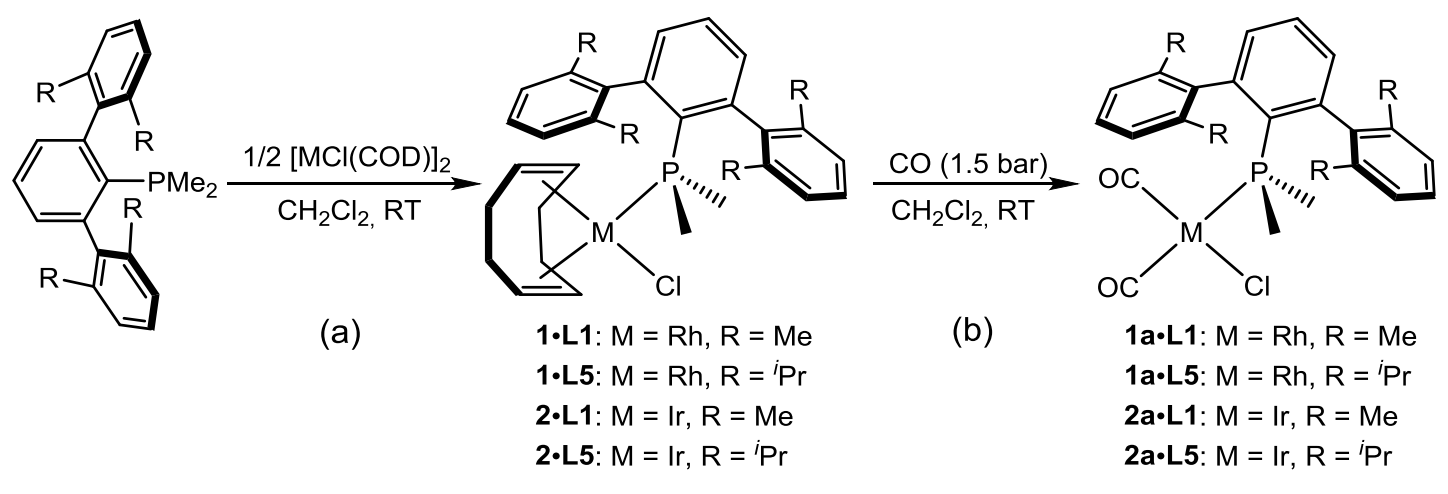

Scheme 3. Synthesis of complexes 1 and 2.

As observed in the ${ }^{31} \mathrm{P}\left\{{ }^{1} \mathrm{H}\right\}$ NMR spectra of complexes $\mathbf{1}$ and $\mathbf{2}$, the resonances due to the phosphorus nucleus of ligands $\mathbf{L 1}$ and $\mathbf{L 5}$ undergo a significant high-frequency shift ( $c$ a. 50 ppm) upon coordination. The ${ }^{31} \mathrm{P}\left\{{ }^{1} \mathrm{H}\right\}$ NMR spectra of adducts $\mathbf{1}$ consist in a doublet due to ${ }^{31} \mathrm{P}$ ${ }^{103} \mathrm{Rh}$ coupling with a ${ }^{1} J_{\mathrm{PRh}}$ value of $144 \mathrm{~Hz}$, while the corresponding resonances in 2 appear as singlets. The ${ }^{1} \mathrm{H}$ NMR spectra of species $\mathbf{1}$ and $\mathbf{2}$ are in agreement with free rotation on the NMR time scale at $25^{\circ} \mathrm{C}$ along the $\mathrm{P}-\mathrm{C}_{\text {aryl }}$ bond, as the four substituents on the terphenyl moiety give rise to a unique set of signals, i.e. one singlet for $\mathbf{1} \cdot \mathbf{L 1}$ and $\mathbf{2} \cdot \mathbf{L} \mathbf{1}$, and two doublets (diasterotopic Me groups) plus one septet for $\mathbf{1} \cdot \mathbf{L 5}$ and $\mathbf{2} \cdot \mathbf{L 5}$. The NMR resonances of the COD ligand are found in the expected range. It is, however, of note the considerable chemical shift difference between the ${ }^{1} \mathrm{H}$ and ${ }^{13} \mathrm{C}$ nuclei of the non-equivalent $=\mathrm{CH}$ groups of about 2.3 and nearly $30 \mathrm{ppm}$, respectively (See Experimental Section). This might be due to the shielding of the methyne units in the cis position with respect to the $\mathrm{P}$ donor by the aromatic electron clouds of the interchangeable aryl substituents of the phosphine in compounds $\mathbf{1}$ and $\mathbf{2}$. The usual bidentate coordination mode of the diene is further demonstrated by the ${ }^{13} \mathrm{C}-{ }^{31} \mathrm{P}$ couplings observed in the ${ }^{13} \mathrm{C}\left\{{ }^{1} \mathrm{H}\right\}$ NMR spectra of adducts $\mathbf{1}$ and $\mathbf{2}$ for the $=\mathrm{CH}$ groups.

Treatment of complexes 1 and 2 with $\mathrm{CO}\left(1.5\right.$ bar of $\left.\mathrm{CO}, \mathrm{CH}_{2} \mathrm{Cl}_{2}, 25^{\circ} \mathrm{C}\right)$ allowed for the substitution of the bidentate COD by two molecules of $\mathrm{CO}$ giving rise to the cis-dicarbonyl derivatives 1a and $\mathbf{2 a}$ (Scheme $3 \mathrm{~b}$ ), which were completely characterized by microanalysis, IR and NMR spectroscopy. In accord with the cis configuration of the carbonyl ligands, the IR spectra of the two compounds show two bands for the $\mathrm{C}-\mathrm{O}$ stretching vibrations. For complex $\mathbf{1 a} \cdot \mathbf{L 1}$, these absorptions appear at 2078 and $1994 \mathrm{~cm}^{-1}$, while for $\mathbf{1 a} \cdot \mathbf{L 5}$ corresponding values are 2070 and $1990 \mathrm{~cm}^{-1}$. These variations denote a small, albeit noticeable, difference in the electron-donor properties of $\mathrm{PMe}_{2} \mathrm{Ar}^{\mathrm{Dipp}_{2}}$ vs. $\mathrm{PMe}_{2} \mathrm{Ar}^{\mathrm{Xyl}}{ }_{2}$. Changing the metal centre from rhodium to iridium evidences a similar shift in the $\bar{v}(\mathrm{CO})$ values, which are now 2067 and 1985 $\mathrm{cm}^{-1}$ for $\mathbf{2 a} \cdot \mathbf{L 1}$ and 2059 and $1978 \mathrm{~cm}^{-1}$ for $\mathbf{2 a} \cdot \mathbf{L 5}$. Moreover, the CO stretching frequencies recorded for the iridium complexes are displaced by roughly $10 \mathrm{~cm}^{-1}$ to lower wavenumber in 
comparison with the rhodium analogues, in agreement with the expected increase in metal basicity.[17] Taking as a representative example complex $\mathbf{1 a} \cdot \mathbf{L 1}$, the diagnostic ${ }^{13} \mathrm{C}$ resonances of the coordinated CO molecules are recorded at $182.5\left(\mathrm{dd},{ }^{2} J_{\mathrm{CP}}=126,{ }^{1} J_{\mathrm{CRh}}=59 \mathrm{~Hz}\right)$ and 182.2 ppm $\left(\mathrm{dd},{ }^{2} J_{\mathrm{CP}}=17,{ }^{1} J_{\mathrm{CRh}}=74 \mathrm{~Hz}\right)$, which are assigned, respectively, to the carbonyl groups in trans and cis disposition with respect to the phosphorus atom. The ${ }^{31} \mathrm{P}\left\{{ }^{1} \mathrm{H}\right\}$ NMR spectra of all these carbonyl species do not differ significantly from the parent COD derivatives.
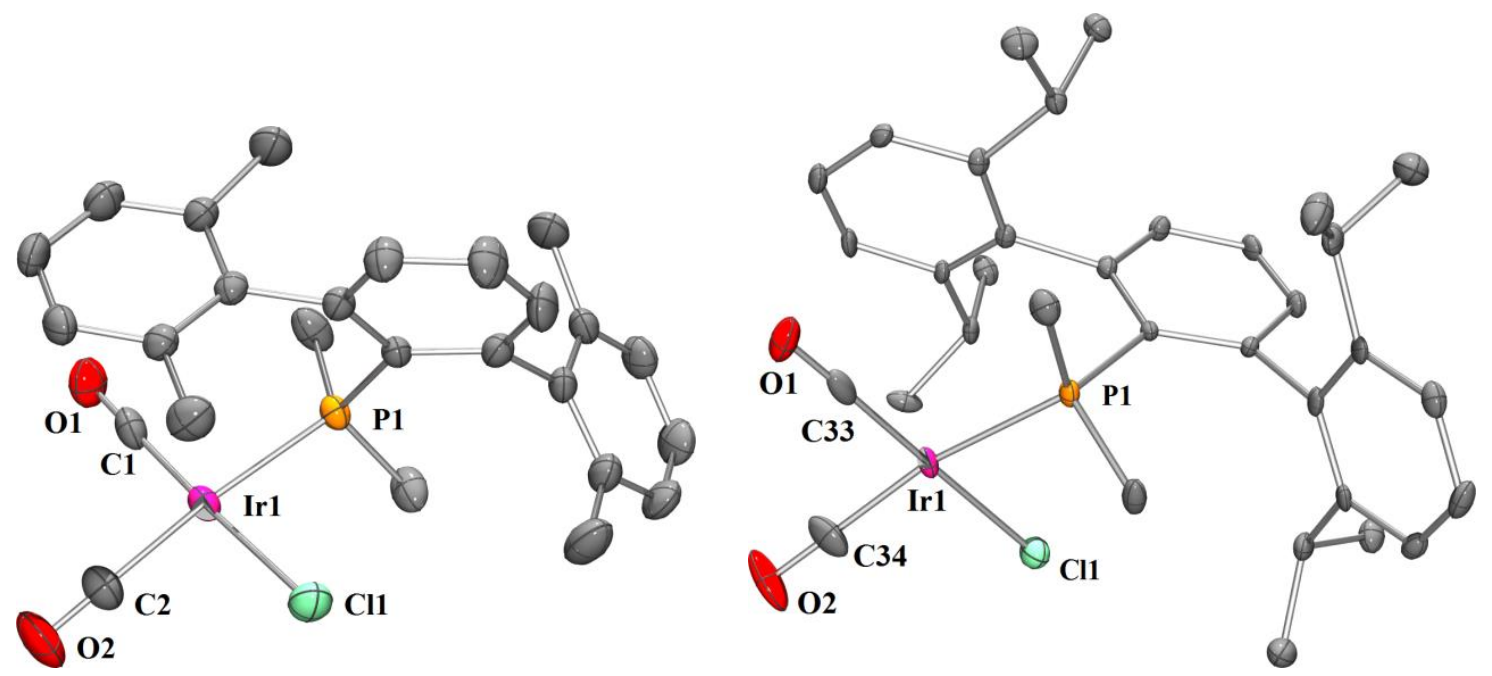

Figure 2. Ortep view of the X-ray molecular structures of $\mathbf{2 a} \cdot \mathbf{L 1}$ (left) and $\mathbf{2 a} \cdot \mathbf{L 5}$ (right) (50\% probability ellipsoids). Selected bond distances $(\AA)$ and angles $\left(^{\circ}\right)$ for $\mathbf{2 a} \cdot \mathbf{L 1}$ : Ir1-P1, 2.359(1); Ir1-Cl1, 2.358(1); Ir1-C1, 1.827(4); Ir1-C2, 1.896(3); C1-O1, 1.152(5); C2-O2, 1.136(4); P1-Ir1-Cl1, 86.57(3); P1-Ir1-C1, 90.9(1); P1-Ir1-C2, 175.1(1); C2-Ir1-Cl1, 89.5(1); C1-Ir1-C2, 93.0(2). Selected bond distances $(\AA)$ and angles $\left(^{\circ}\right)$ for 2a·L5: Ir1-P1, 2.362(1); Ir1-Cl1, 2.350(1); Ir1-C33, 1.837(4); Ir1-C34, 1.887(5); C33-O1, 1.138(5); C34-O2, 1.139(6); P1-Ir1-Cl1, 85.98(4); P1-Ir1-C33, 93.1(1); P1-Ir1-C34, 170.2(2); C34-Ir1-Cl1, 88.4(2); C34-Ir1-C33, 92.5(2).

The molecular structures of complexes 2a in the solid state (Figure 2) were confirmed by X-ray diffraction studies. The two compounds feature similar structural properties. Thus, in both species the metal centre lies in a slightly distorted square-planar environment, with bond angles at the iridium atom between cis ligands ranging from $c a .85^{\circ}$ for the $\mathrm{P}-\mathrm{Ir}-\mathrm{C}$ angle to $c a$. $93^{\circ}$ for the $\mathrm{P}-\mathrm{Ir}-\mathrm{Cl}$ angle. As a consequence of the stronger trans influence of the $\mathrm{P}$-donor ligand compared with the adjacent chloride, the Ir-CO bond distance trans to the phosphine is approximately $0.05 \AA$ longer than the other one. Interestingly, in the two structures one of the flanking aryl rings of the terphenyl group is located almost parallel to the coordination plane, with the shortest Ir...C separation being of approximately $3.5 \AA$ (Figure 3).

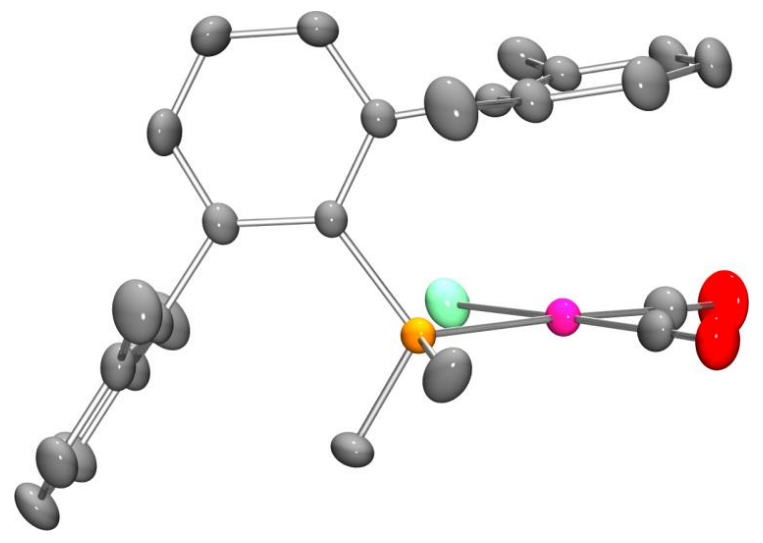


Figure 3. Lateral view of the molecular structure of complex $\mathbf{2} \cdot \mathbf{L} \mathbf{1}$.

To gain further insights into the coordination chemistry of the reported terphenyl ligands, we focused our attention on another typical square-planar cation, such as Pt(II). In order to compare the results illustrated above with those of platinum, we chose the easily available, mononuclear complex, $\mathrm{PtCl}_{2}(\mathrm{COD})$, as the starting material, and tested first its reaction with equimolar amounts of $\mathrm{PMe}_{2} \mathrm{Ar}^{\mathrm{Xyl}_{2}}$. Phosphine $\mathbf{L 1}$ reacted in toluene at $110{ }^{\circ} \mathrm{C}$ with cis$\left[\mathrm{PtCl}_{2}(\mathrm{COD})\right]$ to generate unexpectedly the bis(phosphine) complex 3·L1 (Scheme 4), which resulted from the substitution of the neutral COD ligand by two molecules of $\mathbf{L 1}$ and concomitant isomerization to the trans isomer. Curiously, no evidence for the formation of the mono(phosphine) adduct was found. Consequently, the optimized reaction conditions for the preparation of $\mathbf{3} \cdot \mathbf{L} \mathbf{1}$ required a Pt:PR ${ }_{2} A r$ ' ratio of 1:2 (Scheme 4a).

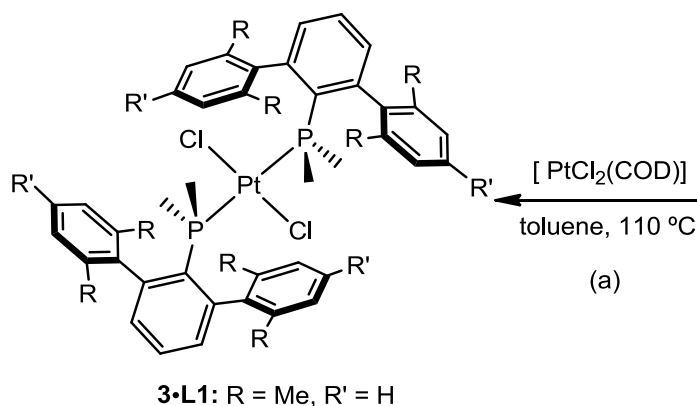

3.L1: $R=M e, R^{\prime}=H$

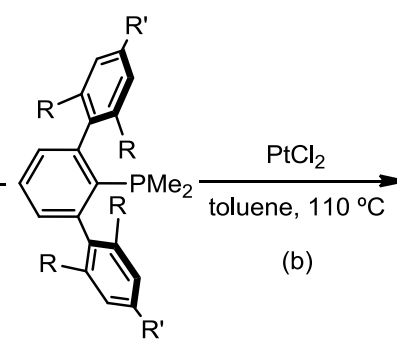

b)

3.L8: $\mathrm{R}=\mathrm{R}^{\prime}={ }^{i} \mathrm{Pr}$

Scheme 4. Synthesis of complexes 3.

Complex $\mathbf{3} \cdot \mathbf{L 1}$ is an air-stable colourless solid, soluble in common organic solvents such as benzene, toluene, chloroform, and dichloromethane. The eight methyl groups of the xylyl fragments give rise to a singlet at $2.07 \mathrm{ppm}$ in the ${ }^{1} \mathrm{H}$ NMR spectrum of $\mathbf{3} \cdot \mathbf{L 1}$. In addition, the methyl groups directly bound to the $\mathrm{P}$ atom appear as an apparent triplet both in the ${ }^{1} \mathrm{H}$ and ${ }^{13} \mathrm{C}\left\{{ }^{1} \mathrm{H}\right\}$ NMR spectra, due to virtual coupling with the two phosphorus nuclei. This clearly demonstrates the trans arrangement of the ligands in this complex, a geometry which is additionally expected upon consideration of the steric properties of the $\mathrm{PMe}_{2} \mathrm{Ar}^{\mathrm{Xyl}_{2}}$ ligands. The ${ }^{31} \mathrm{P}\left\{{ }^{1} \mathrm{H}\right\}$ NMR resonance of complex $\mathbf{3} \cdot \mathbf{L} \mathbf{1}$ appears as a singlet at $-17.3 \mathrm{ppm}\left({ }^{1} J_{\mathrm{PPt}}=2555 \mathrm{~Hz}\right)$ with a downfield variation of $23 \mathrm{ppm}$ with respect to the free phosphine ligand.

An increase in the steric demand of the phosphine ligand with the use of the iso-propyl substituted terphenylphosphines $\mathrm{PMe}_{2} \mathrm{Ar}^{\mathrm{Dipp}_{2}}$ (L5) and $\mathrm{PMe}_{2} \mathrm{Ar}^{\mathrm{Tipp}}{ }_{2}$ (L8), and employing platinum(II) dichloride as the metallic precursor led to formally tri-coordinate 14-electron Pt(II) complexes, 3. L5 and 3. L8, that exhibit a relatively weak secondary interaction between the metal centre and the ipso-carbon atom of a lateral ring of the terphenyl group (Scheme $4 \mathrm{~b}$ ). Compound 3. $\mathbf{L} 5$ was recently utilised as the starting material for $\mathrm{Pt}(0)$ complexes [3k] but its Xray structure is described here for the first time. As evinced by the solid state molecular structure of this species, the phosphine acts as a bidentate ligand, in a $\kappa^{1}-\mathrm{P}, \eta^{1}$-arene coordination mode. Because of this bidentate binding, the NMR characteristics of the terphenyl fragment change significantly with respect to the analogous $\mathrm{Ir}$ and $\mathrm{Rh}$ adducts, indicating unequivocally that the two Dipp rings do not interchange at room temperature. Indeed, in the ${ }^{1} \mathrm{H}$ NMR spectrum of complex $\mathbf{3} \cdot \mathbf{L 5}$ four different doublets are detected for the methyl groups of 
the ortho iso-propyl substituents.[3k] In spite of our efforts, we were unable to demonstrate the existence of a Pt... $C^{\text {Dipp }}$ interaction in solution with the detection of ${ }^{195} \mathrm{Pt}$ satellites for the corresponding ${ }^{13} \mathrm{C}$ resonances.

As anticipated, the X-ray molecular structure of 3.L5 (Figure 4) features an approximate square-planar coordination geometry, with two cis $\mathrm{Pt}-\mathrm{Cl}$ bonds and a $\mathrm{Pt}-\mathrm{P}$ bond, and with the fourth coordination site occupied by the ipso-carbon atom of a Dipp ring. The Pt ... $\mathrm{C}_{\text {ipso }}$ separation of 2.234(5) $\AA$ suggests the existence of a weak bonding interaction between the two atoms involved. Taking into account that the closest ortho carbon atom of the Dipp ring participating in this interaction is situated at $c a .2 .5 \AA$ from the platinum centre, a nonsymmetric, $\eta^{2}$-arene coordination cannot definitely be ruled out.[18] The difference of approximately $0.05 \AA$ between the two $\mathrm{Pt}-\mathrm{Cl}$ bond lengths is also in agreement with the weakness and poor trans influence of the $\mathrm{Pt} \cdots \mathrm{C}_{i p s o}$ bonding interaction compared to the $\mathrm{Pt}-\mathrm{P}$ one. Complex 3. L8, that contains the even bulkier $\mathrm{Ar}^{\mathrm{Tipp}} 2$ group, was prepared analogously to 3. L5 and its spectroscopic characteristics are also consistent with a mononuclear tri-coordinate $\mathrm{T}$-shaped structure, complemented by a $\mathrm{Pt}-\mathrm{C}_{\text {arene }}$ interaction.

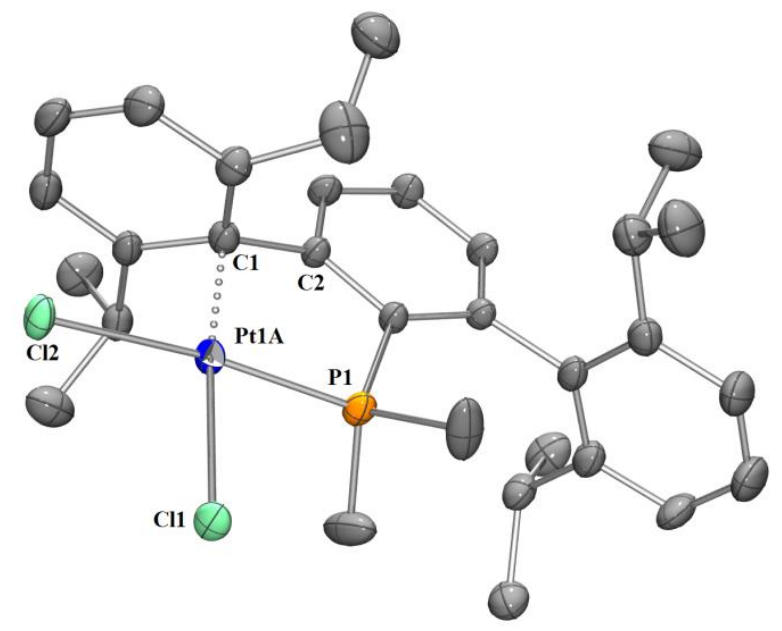

Figure 4. Ortep view of the X-ray molecular structure of $\mathbf{3} \cdot \mathbf{L 5}$ (30\% probability ellipsoids). Selected bond distances (A) and angles $\left({ }^{\circ}\right)$ for 3·L5: Pt1A-P1, 2.215(1); Pt1A-Cl1, 2.350(1); Pt1A-Cl2, 2.401(1); Pt1A-C1, 2.234(5); P1-Pt1A-Cl1, 85.66(4); Cl1-Pt1A-Cl2, 87.01(4); C1-Pt1A-P1, 82.8(1).

The $\eta^{1}$-arene interaction observed in the solid state structure of $\mathbf{3} \cdot \mathbf{L 5}$ is labile and can readily be substituted by coordination of carbon monoxide, to generate the corresponding

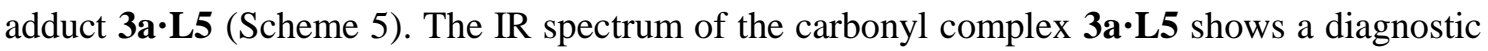
absorption at $2114 \mathrm{~cm}^{-1}$, with wavenumber similar to those found for other platinum(II) compounds. [12d, 19]

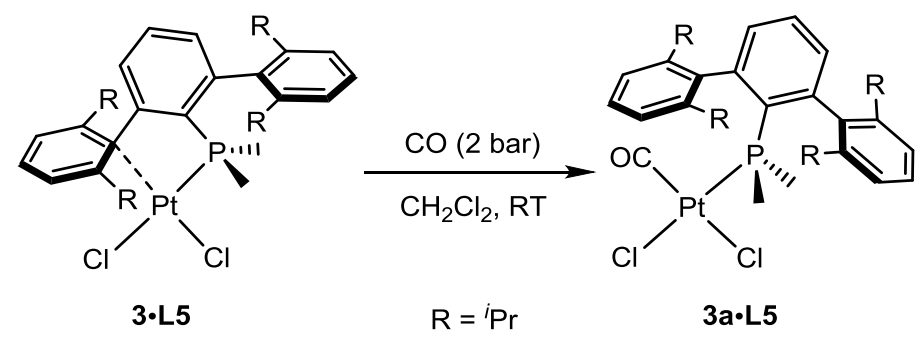

Scheme 5. Generation of the carbonyl complex $\mathbf{3 a} \cdot \mathbf{L 5}$. 
As a consequence of the usual $\kappa^{1}-\mathrm{P}$ coordination of the phosphine, the spectroscopic equivalence of the two flanking aryl rings in solution, due to fast rotation around the $\mathrm{P}-\mathrm{C}_{\text {aryl }}$ bond, is restored. In fact, similarly to what was observed for the related iridium and rhodium derivatives, in the ${ }^{1} \mathrm{H}$ NMR spectrum of $\mathbf{3 a} \cdot \mathbf{L 5}$ only two doublets for all the iso-propyl methyl groups and one septet for the adjacent methyne units are detected.

Electronic and steric properties of the terphenylphosphines, L. The electronic and steric properties of ligands $\mathbf{L}$ were studied by computational and NMR methods, by quantifying their molecular electrostatic potential (MESP) and by measuring the volume of the phosphines in a given complex (buried volume), as shall be described below.

We attempted to probe the $\sigma$-donor ability[20-22] of the terphenylphosphines $\mathbf{L}$ by measuring the magnitude of the ${ }^{31} \mathrm{P}^{77} \mathrm{Se}$ scalar coupling constants, ${ }^{1} J_{\mathrm{PSe}},[20,21]$ of their selenide derivatives by NMR methods, and also by computational studies.[22] Smaller values of ${ }^{1} J_{\mathrm{PSe}}$ are generally associated with higher phosphine basicity[20] although steric and solvent effects are also important.[21] In fact, as shown recently by Beckmann, Süslüyand, and Kunz, [21d] electronic and steric effects may contribute in opposite directions and influence the value of the ${ }^{1} J_{\mathrm{PSe}}$ spin-spin coupling constant.

Despite these limitations, we generated some terphenylphosphine selenides, $\mathbf{L} \cdot \mathbf{S e}$, in NMR tube experiments, by treatment of $\mathrm{C}_{6} \mathrm{D}_{6}$ solutions of the phosphine with selenium powder, at room temperature or at $60{ }^{\circ} \mathrm{C}$ (as appropriate), for several hours, until full conversion was achieved (Scheme 6). The corresponding ${ }^{31} \mathrm{P}^{77} \mathrm{Se}$ coupling constants were measured from the selenium satellites (7.6\% natural abundance) of their ${ }^{31} \mathrm{P}$ resonance, and their values are given in the Experimental Section. Here we focus the discussion on the dimethylterphenyl phosphines $\mathrm{PMe}_{2} \mathrm{Ar}^{\mathrm{Xy12}}$ (L1) and $\mathrm{PMe}_{2} \mathrm{Ar}^{\mathrm{Dipp} 2}$ (L5) for which $\mathrm{Rh}$ and Ir dicarbonyl complexes cis$\left[\mathrm{MCl}(\mathrm{CO})_{2}(\mathrm{~L})\right](\mathbf{1 a} \cdot \mathbf{L}$ and $\mathbf{2 a} \cdot \mathbf{L}$, see Scheme 3$)$ were described in a previous section. It is worth remarking that the $\bar{v}(\mathrm{CO})$ values (vide supra) recorded for the iridium complexes, $\mathbf{2 a} \cdot \mathbf{L} \mathbf{1}$ and $\mathbf{2 a} \cdot \mathbf{L 5}$, are very similar to those reported by Nolan and coworkers for analogous complexes of some biarylphosphines, denoting similar electron-donating capacity.[22d] For comparative purposes we have also studied selenide derivatives of the other $\mathrm{PMe}_{2} \mathrm{Ar}^{\prime}$ phosphines discussed in this work, namely $\mathrm{PMe}_{2} \mathrm{Ar}^{\mathrm{Mes}_{2}}$,[13a-c] $\mathrm{PMe}_{2} \mathrm{Ar}^{\mathrm{Tipp}_{2}}$ (L8), and $\mathrm{PMe}_{2} \mathrm{Ar}^{\mathrm{Ph}_{2}}$ (L11).

All of the above $\mathrm{PMe}_{2} \mathrm{Ar}$ ' phosphines exhibit ${ }^{1} J_{\mathrm{PSe}}$ couplings close to the $710 \mathrm{~Hz}$ value reported for $\mathrm{PMe}_{2} \mathrm{Ph}$,[21d] which can be taken as indicative of comparable overall donor ability. For this series of dimethylterphenyl phosphines, the steric characteristics of the flanking aryl ring substituents at positions 2' and 6', viz $\mathrm{H}$ (L11), $\mathrm{Me}$ (L1 and $\mathrm{PMe}_{2} \mathrm{Ar}^{\mathrm{Mes}_{2}}$ ), and ${ }^{i} \operatorname{Pr}(\mathbf{L 5}$ and L8), do not appear to interfere with the electronic properties, as the corresponding ${ }^{1} J_{\mathrm{PSe}}$ coupling constant vary in the expected manner: 713, L11; 709, L1 and 708, $\mathrm{PMe}_{2} \mathrm{Ar}^{\mathrm{Mes}_{2} ;} 704$ and $703 \mathrm{~Hz}$, $\mathbf{L 5}$ and $\mathbf{L 8}$, respectively.

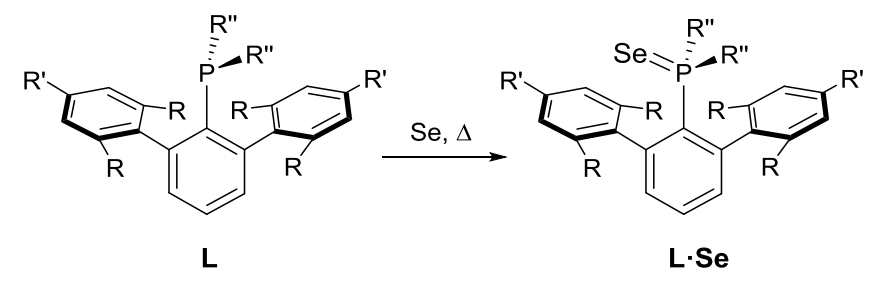

Scheme 6. Synthesis of the phosphine selenides $\mathbf{L} \cdot$ Se. 
Other $\mathrm{PR}_{2} \mathrm{Ar}$ ' ligands prepared in this work feature larger ${ }^{1} J_{\mathrm{PSe}}$ values. For instance, for molecules of type $\mathrm{PEt}_{2} \mathrm{Ar}^{\prime}$, coupling constants in the range $715-722 \mathrm{~Hz}$, which are sensitive to

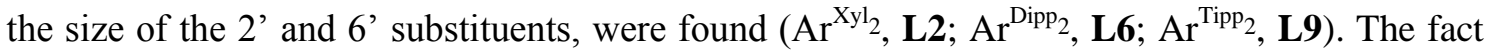
that these values are superior to those of the analogous $\mathrm{PMe}_{2} \mathrm{Ar}$ ' ligands is most likely due to steric factors. It is worth noting in this regard that ${ }^{31} \mathrm{P}_{-}{ }^{77} \mathrm{Se}$ couplings for $\mathrm{PMe}_{3}$ and $\mathrm{P}^{t} \mathrm{Bu}_{3}$ selenides (684 and $692 \mathrm{~Hz}$, respectively [21d]) are clearly opposite to expectations based of the values of their Tolman electronic parameters (2064.1 and $2056.1 \mathrm{~cm}^{-1}$, respectively).[22a]

In addition to the above, we have calculated the values of the molecular electrostatic potential $\left(\mathrm{V}_{\min }\right)$ of some selected ligands $\mathbf{L}$ and compared them with those of common phosphines (see the computational details and the Supporting Information). $V_{\min }$ has been correlated with the electronic properties of $\mathrm{PR}_{3}$ ligands,[22b] with larger values of $\mathrm{V}_{\text {min }}$ corresponding to phosphines with larger $\sigma$-donating abilities. Our calculations yield values of $\mathrm{V}_{\text {min }}$ of -43.36 and $-41.99 \mathrm{kcal} \cdot \mathrm{mol}^{-1}$ for $\mathbf{L 1}$ and $\mathbf{L 5}$ respectively, both $\mathrm{PMe}_{2} \mathrm{Ar}^{\prime}$ phosphines, and $-48.64 \mathrm{kcal} \cdot \mathrm{mol}^{-1}$ for $\mathrm{PEt}_{2} \mathrm{Ar}^{\mathrm{Xyl} 2}(\mathbf{L 2})$. The former values are intermediate between those of Cy-JohnPhos $\left(\mathrm{V}_{\min }=-48.59 \mathrm{kcal} \cdot \mathrm{mol}^{-1}\right.$; Scheme 7) and $\mathrm{PPh}_{3}\left(\mathrm{~V}_{\min }=-36.33 \mathrm{kcal} \cdot \mathrm{mol}^{-1}\right)$, and close to $\mathrm{V}_{\text {min }}$ calculated for $\mathrm{PMe}_{3}$ at $-45.05 \mathrm{kcal} \cdot \mathrm{mol}^{-1}$.

As it is known, the steric properties of ligands $\mathbf{L}$ are best accounted for by measuring the percentage of the volume of an arbitrary sphere (coordination sphere) that they occupy (Figure 5). The method chosen to calculate the buried volume $\left(\% \mathrm{~V}_{\text {Bur }}\right)$ requires experimental or calculated geometries of the ligands in metal complexes.[23] In this case crystallographic data of complexes $\mathbf{2 a} \cdot \mathbf{L 1}$ and $\mathbf{2 a} \cdot \mathbf{L 5}$ have been used, in addition to their DFT-optimized geometries (see the computational details). The good agreement obtained between the two approaches led us to calculate the $\% \mathrm{~V}_{\mathrm{Bur}}$ for the remaining phosphines $\mathbf{L}$ from the DFT-optimized geometries of the corresponding $\left[\mathrm{IrCl}(\mathrm{CO})_{2}(\mathrm{~L})\right]$ complexes.
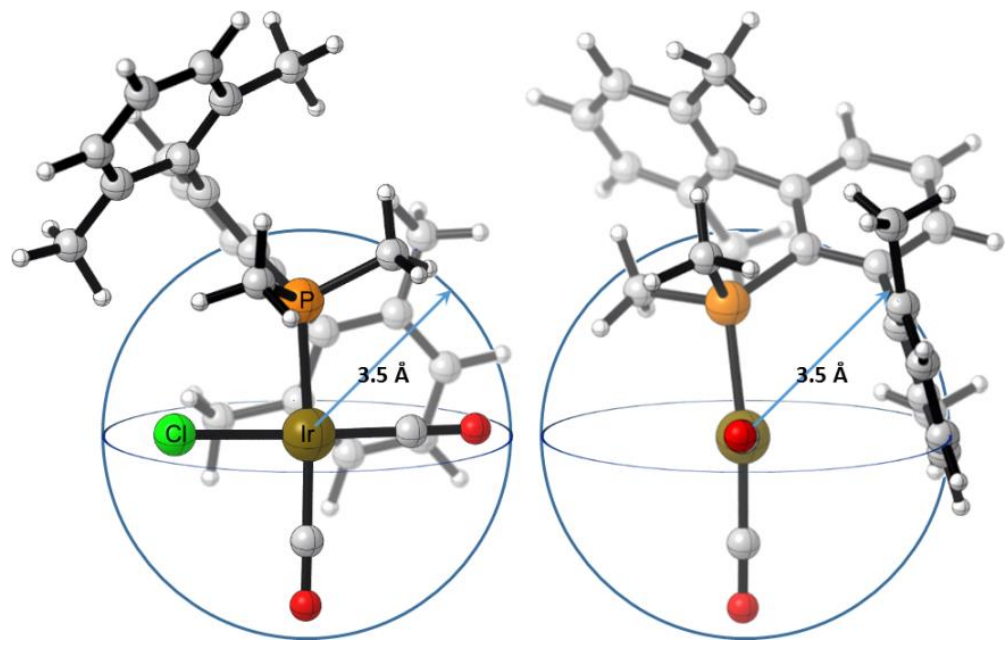

Figure 5. Front and side views of the DFT-optimized geometry of complex $\mathbf{2} \cdot \mathbf{a} \cdot \mathbf{L} \mathbf{1}$ circumscribed in a sphere of radius $3.5 \AA$ as used in the calculation of the ligands $\% \mathrm{~V}_{\text {Bur. }}$.

In order to compare our results with other reported in the literature for bulky phosphines[22e] (Scheme 7), the sphere radius was set to $3.5 \AA$ and the distance between the phosphorus atom and the centre of the sphere was set to $2.28 \AA$. Additional calculations have been done using the actual (measured from X-ray data or DFT-optimized) $\mathrm{Ir}-\mathrm{P}$ bond lengths in the metal complexes. Table 2 shows the results of these calculations. 


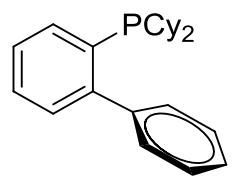

Cy-JohnPhos

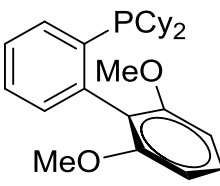

S-Phos

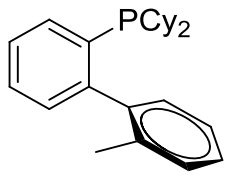

Me-Phos

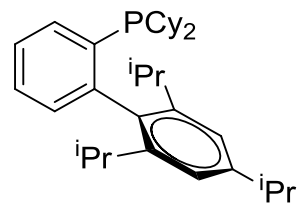

X-Phos

Scheme 7. Bulky biaryl phosphines.

Table 2. $\% \mathrm{~V}_{\text {Bur }}$ of ligands $\mathbf{L}$ in complexes $\left[\operatorname{IrCl}(\mathbf{C O})_{2}(\mathbf{L})\right]$

\begin{tabular}{|c|c|c|}
\hline \multirow{2}{*}{ Ligand } & \multicolumn{2}{|c|}{$\% \mathrm{~V}_{\text {bur }} \mathbf{2 a} \cdot \mathbf{L n}$} \\
\hline & $\mathrm{a}$ & $\mathrm{b}$ \\
\hline L1 & $43.0(42.4)$ & 41.4 (41.4) \\
\hline $\mathbf{L 2}$ & 44.1 & 42.2 \\
\hline L3 & 44.5 & 42.6 \\
\hline L4 & 43.9 & 42.1 \\
\hline L5 & $44.7(44.2)$ & $43.4(43.2)$ \\
\hline L6 & 45.3 & 43.6 \\
\hline L7 & 45.7 & 44.0 \\
\hline L8 & 45.4 & 44.1 \\
\hline L9 & 44.2 & 42.3 \\
\hline L10 & 42.4 & 40.8 \\
\hline L11 & 41.5 & 40.0 \\
\hline $\mathrm{PPhCy}_{2}$ & 31.6 & - \\
\hline Cy-JohnPhos & $35.0^{\mathrm{c}}$ & - \\
\hline Me-Phos & $35.4^{\mathrm{c}}$ & - \\
\hline S-Phos & $32.6^{\mathrm{c}}$ & - \\
\hline X-Phos & $33.4^{\mathrm{c}}$ & - \\
\hline $\mathbf{P}^{t} \mathbf{B u}_{3}$ & $36^{\mathrm{d}}$ & - \\
\hline
\end{tabular}

${ }^{\mathrm{a}}$ Distance $\mathrm{P}$-Ir set at $2.28 \AA{ }^{\mathrm{b}}$ distance P-Ir from DFT-optimized or crystallographic data (in parenthesis); ${ }^{\mathrm{c}}$ from ref. $22 \mathrm{~d}$ (in $\left[\operatorname{IrCl}(\mathrm{CO})_{2}(\mathrm{~L})\right]$ using crystallographic data); ${ }^{\mathrm{d}}$ calculated in $\left[\operatorname{IrCl}(\mathrm{CO})_{2}(\mathrm{~L})\right]$ using crystallographic data from reference [24].

Analysis of the above data shows that phosphines L1-11 are very bulky, their $\% \mathrm{~V}_{\text {Bur }}$ in complexes cis-[ $\left.\operatorname{IrCl}(\mathrm{CO})_{2}(\mathrm{~L})\right]$ varying between $45.4 \%$ and $41.5 \%$. These values exceed those found in the literature for biaryl tertiary phosphines in analogous complexes, which are in the range 35.4-31.6\%.[22e] These percentages are however dependent on the orientation of the phosphine in the metal complex and therefore this matter merits further discussion. Additional calculations of the $\% \mathrm{~V}_{\text {Bur }}$ of $\mathbf{L 5}$ in the platinum complex $\mathbf{3} \cdot \mathbf{L 5}$ using crystallographic data gives a larger occupancy percentage of $56.6 \%$. In the gold complex of this ligand, $\mathrm{AuCl}\left(\mathrm{PMe}_{2} \mathrm{Ar}^{\mathrm{Dipp}_{2}}\right)$, the results using crystallographic[13e] and DFT data are comparable to the previous case with 49.5 and $50.5 \% \mathrm{~V}_{\text {Bur }}$, respectively. Examination of the molecular geometries of these complexes reveal that in all cases one of the flanking aryl rings of the terphenyl phosphine is placed sufficiently close to the metal centre as to be partially embedded in the $3.5 \AA$ radius sphere 
defined for the calculation of the $\% \mathrm{~V}_{\text {Bur }}$ (Figure 5). As already discussed, in the iridium dicarbonyl complexes $\mathbf{2 a} \cdot \mathbf{L} \mathbf{1}$ and $\mathbf{2 a} \cdot \mathbf{L 5}$, the flanking aryl is placed above the iridium coordination plane, with the closest contact at $c a .3 .5 \AA$. A similar situation occurs in the gold complex, in which close contacts of $c a .3 .2 \AA$ exist between the gold atom and one of the Dipp rings. In the platinum complex 3. $\mathbf{L 5}$ the phosphine acts as bidentate ligand, with one of the Dipp rings occupying one coordination site of the metal with the closest interaction Pt $\cdots \mathrm{C}$ being 2.234(5) $\AA$. Conversely, in the $\left[\operatorname{IrCl}(\mathrm{CO})_{2}(\mathrm{~L})\right]$ complexes with the biaryl phosphines of Table 2 , the biaryl fragments are oriented away from the metal centre and therefore they have smaller contributions to the steric bulk of the phosphines. However, their $\% \mathrm{~V}_{\text {Bur }}$ increases to values in the range $46.7-53.1 \%$ when this parameter is calculated in complexes of type $\mathrm{AuCl}(\mathrm{L})$, [22d] in which the biaryl phosphines adopt conformations similar to that of $\mathbf{L 5}$ in $\mathbf{3 a} \cdot \mathbf{L 5}$.

\section{Experimental section.}

General considerations. All preparations and manipulations were carried out under oxygenfree argon or nitrogen, using conventional Schlenk techniques and, when specified, at low temperature. Solvents were rigorously dried and degassed before use. $\mathrm{PCl}_{3}$ was distilled prior to use and kept under a nitrogen atmosphere. Solution NMR spectra were recorded on Bruker Avance DPX-300, Avance DRX-400, Avance DRX-500, and 400 Ascend/R spectrometers. The ${ }^{1} \mathrm{H}$ and ${ }^{13} \mathrm{C}$ resonances of the solvent were used as the internal standard and the chemical shifts are reported relative to TMS. $\mathrm{PtCl}_{2}$ (COD),[25] $\mathrm{IrCl}(\mathrm{COD})$,[26] $\mathrm{RhCl}(\mathrm{COD})$,[27] L1,[13d] $\mathbf{L 5},[3 \mathrm{k}] \mathrm{PMe}_{2} \mathrm{Ar}^{\mathrm{Mes}},[13 \mathrm{a}]$ and $\mathbf{3} \cdot \mathbf{L 5}[3 \mathrm{k}]$ were prepared according to literature methods. Crystals suitable for X-ray diffraction of $\mathbf{3 \cdot L 5}$ were obtained by slow diffusion of hexanes into a dichloromethane solution of the compound at $-23{ }^{\circ} \mathrm{C}$. Other chemicals were commercially available and used as received.

Synthesis and characterization of $\mathbf{P R}_{2} \mathbf{A r}$ ' ligands. The synthesis of $\mathrm{PR}_{2} \mathrm{Ar}$ ' ligands was carried out as described in the following general procedure. Specific details, i.e. spectroscopic characterization, elemental analysis or mass spectrometry, and yields are given below for each phosphine ligand. The value of ${ }^{1} J_{\mathrm{PSe}}$ for the corresponding selenide, $\mathbf{L} \cdot \mathbf{S e}$, is also given. We commonly employ for our work the dimethyl phosphines $\mathrm{PMe}_{2} \mathrm{Ar}^{\mathrm{Xyl}}{ }_{2}$ (L1), $\mathrm{PMe}_{2} \mathrm{Ar}^{\mathrm{Dipp}_{2}}$ (L5), and $\mathrm{PMe}_{2} \mathrm{Ar}^{\mathrm{Tipp}} 2$ (L8).[3k, 13d,e] we prepare these ligands in a several-gram scale (4-6 g) using the general procedure detailed below. Characterization data for $\mathbf{L 1}$ and $\mathbf{L 5}$ have been reported,[3k,13d] those for $\mathbf{L 8}$ are given later in this section.

General synthesis. A solution of freshly prepared $\mathrm{Mg}\left(\mathrm{Ar}^{\prime}\right) \mathrm{Br}(c a .40 \mathrm{mmol})$ in THF (ca. 60 $\mathrm{mL}$ ) was added dropwise to a solution of an equimolar amount of $\mathrm{PCl}_{3}$ in THF (ca. $40 \mathrm{~mL}$ ) at $-80{ }^{\circ} \mathrm{C}$. The reaction mixture was allowed to reach slowly the room temperature and stirred overnight. All volatiles were removed by evaporation under reduced pressure and the solid residue was extracted three times with pentane $(3 \times 50 \mathrm{~mL})$. The combined organic fractions were dried under vacuum giving a mixture of the three dihalophosphines $\mathrm{PCl}_{2} \mathrm{Ar}^{\prime}, \mathrm{PBr}_{2} \mathrm{Ar}$ ', and $\mathrm{PCl}(\mathrm{Br}) \mathrm{Ar}$ '(three singlets in the ${ }^{31} \mathrm{P}\left\{{ }^{1} \mathrm{H}\right\} \mathrm{NMR}$ at about $145-160 \mathrm{ppm}$ ), as a pale yellow solid, which was redissolved in THF $(50 \mathrm{~mL})$. A solution of $\mathrm{Mg}(\mathrm{R}) \mathrm{Br}$ in $\mathrm{Et}_{2} \mathrm{O}$ (ca. $82 \mathrm{mmol}$ ) was added dropwise at $-80{ }^{\circ} \mathrm{C}$, the mixture was allowed to reach slowly the room temperature, and stirred overnight. The volatiles were removed under reduced pressure and the solid residue was extracted with pentane $(3 \times 50 \mathrm{~mL})$. The combined of organic fractions was taken to dryness affording a pale yellow solid which was washed with $\mathrm{MeOH}$ at $0{ }^{\circ} \mathrm{C}$. 
Synthesis of SePR $\mathbf{R}_{2}$ Ar'species. $0.025 \mathrm{mmol}$ of the corresponding phosphines was placed in a standard NMR tube with an excess of elemental selenium. Non-distilled $\mathrm{C}_{6} \mathrm{D}_{6}$ was then added $(0.6 \mathrm{~mL})$ and the tube was sealed. When needed, the reaction mixtures were heated up to $60{ }^{\circ} \mathrm{C}$ for several hours until reaching full conversion. ${ }^{31} \mathrm{P}-{ }^{77} \mathrm{Se}$ scalar couplings were directly measured from the ${ }^{31} \mathrm{P}\left\{{ }^{1} \mathrm{H}\right\}$ NMR spectra of these solutions at $25{ }^{\circ} \mathrm{C}$ in 400 Ascend/R spectrometer.

$\mathbf{P E t}_{2} \mathbf{A r}^{\mathbf{X y l}_{2}}$, L2. Yield: $0.55 \mathrm{~g}, 40 \%$. Anal. Calc. for $\mathrm{C}_{26} \mathrm{H}_{31} \mathrm{P}: \mathrm{C}, 83.39 ; \mathrm{H}, 8.34$. Found: C, 83.4; $\mathrm{H}, 8.4 .{ }^{1} \mathrm{H}$ NMR $\left(400 \mathrm{MHz}, 25{ }^{\circ} \mathrm{C}, \mathrm{CDCl}_{3}\right): \delta 7.38\left(\mathrm{t}, 1 \mathrm{H},{ }^{3} \mathrm{~J}_{\mathrm{HH}}=7.5 \mathrm{~Hz}, p-\mathrm{C}_{6} \mathrm{H}_{3}\right), 7.18(\mathrm{dd}, 2 \mathrm{H}$, $\left.{ }^{3} J_{\mathrm{HH}}=8.2 \mathrm{~Hz},{ }^{3} J_{\mathrm{HH}}=6.8 \mathrm{~Hz}, p-\mathrm{Xyl}\right), 7.08\left(\mathrm{~d}, 4 \mathrm{H},{ }^{3} J_{\mathrm{HH}}=7.2 \mathrm{~Hz}, m-\mathrm{Xyl}\right), 6.97\left(\mathrm{dd}, 2 \mathrm{H},{ }^{3} J_{\mathrm{HH}}=\right.$ $\left.7.6 \mathrm{~Hz},{ }^{4} J_{\mathrm{HP}}=1.9 \mathrm{~Hz}, m-\mathrm{C}_{6} \mathrm{H}_{3}\right), 2.06(\mathrm{~s}, 12 \mathrm{H}, \mathrm{Me}-\mathrm{Xyl}), 1.23\left(\mathrm{ddq}, 2 \mathrm{H},{ }^{2} J_{\mathrm{HH}}=13.8 \mathrm{~Hz},{ }^{3} J_{\mathrm{HH}}=\right.$ $\left.7.8 \mathrm{~Hz},{ }^{2} J_{\mathrm{HP}}=1.0 \mathrm{~Hz}, \mathrm{CH}_{2}\right), 1.04\left(\mathrm{ddq}, 2 \mathrm{H},{ }^{2} J_{\mathrm{HH}}=13.7 \mathrm{~Hz},{ }^{3} J_{\mathrm{HH}}=7.5 \mathrm{~Hz},{ }^{2} J_{\mathrm{HP}}=2.2 \mathrm{~Hz}, \mathrm{CH}_{2}\right)$, $0.75\left(\mathrm{dt}, 6 \mathrm{H},{ }^{3} J_{\mathrm{HH}}=7.7 \mathrm{~Hz},{ }^{3} J_{\mathrm{HP}}=17.3 \mathrm{~Hz}, \mathrm{CH}_{3}-\mathrm{Et}\right) \mathrm{ppm} .{ }^{13} \mathrm{C}\left\{{ }^{1} \mathrm{H}\right\} \mathrm{NMR}\left(100.57 \mathrm{MHz}, 25{ }^{\circ} \mathrm{C}\right.$, $\left.\mathrm{CDCl}_{3}\right): \delta 147.3\left(\mathrm{~d},{ }^{2} J_{\mathrm{CP}}=15 \mathrm{~Hz}, o-\mathrm{C}_{6} \mathrm{H}_{3}\right), 142.8\left(\mathrm{~d},{ }^{3} J_{\mathrm{CP}}=5 \mathrm{~Hz}, \mathrm{C}_{\mathrm{ipso}}-\mathrm{Xyl}\right), 136.3\left(\mathrm{~d},{ }^{4} J_{\mathrm{CP}}=1\right.$ $\mathrm{Hz}, o-\mathrm{Xyl}), 135.8\left(\mathrm{~d},{ }^{1} J_{\mathrm{CP}}=29 \mathrm{~Hz}, \mathrm{C}_{\mathrm{ipso}}-\mathrm{C}_{6} \mathrm{H}_{3}\right), 129.6\left(\mathrm{~s},{ }^{3} J_{\mathrm{CP}}=2.8 \mathrm{~Hz}, m-\mathrm{C}_{6} \mathrm{H}_{3}\right), 128.9$ (s, $p$ $\left.\mathrm{C}_{6} \mathrm{H}_{3}\right), 127.2$ (s, $p$-Xyl), 127.1 (s, $\left.m-\mathrm{Xyl}\right), 21.4\left(\mathrm{~d},{ }^{5} J_{\mathrm{CP}}=2 \mathrm{~Hz}, \mathrm{Me}-\mathrm{Xyl}\right), 18.6\left(\mathrm{~d},{ }^{1} J_{\mathrm{CP}}=13 \mathrm{~Hz}\right.$, $\left.\mathrm{CH}_{2}\right), 12.2\left(\mathrm{~d},{ }^{2} J_{\mathrm{CP}}=22 \mathrm{~Hz}, \mathrm{CH}_{3}\right.$-Et) ppm. ${ }^{31} \mathrm{P}\left\{{ }^{1} \mathrm{H}\right\} \mathrm{NMR}\left(161.9 \mathrm{MHz}, 25{ }^{\circ} \mathrm{C}, \mathrm{CDCl}_{3}\right): \delta-8.0(\mathrm{~s})$ ppm. L2·Se. ${ }^{31} \mathrm{P}\left\{{ }^{1} \mathrm{H}\right\}$ NMR $\left(161.9 \mathrm{MHz}, 25^{\circ} \mathrm{C}, \mathrm{C}_{6} \mathrm{D}_{6}\right): \delta 37.1\left({ }^{1} J_{\mathrm{PSe}}=716 \mathrm{~Hz}\right) \mathrm{ppm}$.

$\mathbf{P}\left(\mathbf{C}_{3} \mathbf{H}_{5}\right)_{2} \mathbf{A r}^{\mathrm{Xyl}_{2}}$, L3. Yield: 0.07 g, 50\%. Anal. Calc. for $\mathrm{C}_{28} \mathrm{H}_{31} \mathrm{P}: \mathrm{C}, 84.39 ; \mathrm{H}, 7.84$. Found: C, 84.1; H, 8.1. ${ }^{1} \mathrm{H}$ NMR $\left(400 \mathrm{MHz}, 2{ }^{\circ} \mathrm{C}, \mathrm{CDCl}_{3}\right): \delta 7.39$ (t, $\left.1 \mathrm{H},{ }^{3} J_{\mathrm{HH}}=7.6 \mathrm{~Hz}, p-\mathrm{C}_{6} \mathrm{H}_{3}\right), 7.18(\mathrm{t}$, $\left.2 \mathrm{H},{ }^{3} J_{\mathrm{HH}}=7.6 \mathrm{~Hz}, p-\mathrm{Xyl}\right), 7.09\left(\mathrm{~d}, 4 \mathrm{H},{ }^{3} J_{\mathrm{HH}}=7.5 \mathrm{~Hz}, m-\mathrm{Xyl}\right), 6.98\left(\mathrm{dd},{ }^{3} J_{\mathrm{HH}}=7.5 \mathrm{~Hz},{ }^{4} J_{\mathrm{HP}}=\right.$ $\left.2.1 \mathrm{~Hz}, m-\mathrm{C}_{6} \mathrm{H}_{3}\right), 5.41\left(\mathrm{~m}, 2 \mathrm{H}, \mathrm{PCH}_{2} \mathrm{CHCH}_{2}\right), 4.80\left(\mathrm{~m}, 2 \mathrm{H}, \mathrm{PCH}_{2} \mathrm{CHCH}_{2}\right), 4.71(\mathrm{~m}, 2 \mathrm{H}$, $\left.\mathrm{PCH}_{2} \mathrm{CHCH}_{2}\right), 2.09$ (s, $\left.12 \mathrm{H}, \mathrm{Me}-\mathrm{Xyl}\right), 1.94\left(\mathrm{~d}, 4 \mathrm{H},{ }^{3} J_{\mathrm{HH}}=7.6 \mathrm{~Hz}, \mathrm{PCH}_{2} \mathrm{CHCH}_{2}\right)$ ppm. ${ }^{13} \mathrm{C}\left\{{ }^{1} \mathrm{H}\right\}$ NMR $\left(100.57 \mathrm{MHz}, 25{ }^{\circ} \mathrm{C}, \mathrm{CDCl}_{3}\right): \delta 146.7\left(\mathrm{~d},{ }^{2} J_{\mathrm{CP}}=15 \mathrm{~Hz}, o-\mathrm{C}_{6} \mathrm{H}_{3}\right), 142.3\left(\mathrm{~d},{ }^{3} J_{\mathrm{CP}}=4 \mathrm{~Hz}\right.$, $\left.\mathrm{C}_{\mathrm{ipso}} \mathrm{Xyl}\right), 136.3$ (s, o-Xyl), $135.3\left(\mathrm{~d},{ }^{2} J_{\mathrm{CP}}=12 \mathrm{~Hz}, \mathrm{PCH}_{2} \mathrm{CHCH}_{2}\right), 134.8\left(\mathrm{~d},{ }^{1} J_{\mathrm{CP}}=34 \mathrm{~Hz}, \mathrm{C}_{\mathrm{ipso}}{ }^{-}\right.$ $\left.\mathrm{C}_{6} \mathrm{H}_{3}\right), 129.8\left(\mathrm{~s}, m-\mathrm{C}_{6} \mathrm{H}_{3}\right), 129.0\left(\mathrm{~s}, p-\mathrm{C}_{6} \mathrm{H}_{3}\right), 127.5(\mathrm{~s}, p-\mathrm{Xyl}), 127.4(\mathrm{~s}, m-\mathrm{Xyl}), 116.4\left(\mathrm{~d},{ }^{3} J_{\mathrm{CP}}=\right.$ $\left.10 \mathrm{~Hz}, \mathrm{PCH}_{2} \mathrm{CHCH}_{2}\right), 30.2\left(\mathrm{~d},{ }^{1} J_{\mathrm{CP}}=18 \mathrm{~Hz}, \mathrm{PCH}_{2} \mathrm{CHCH}_{2}\right), 21.5\left(\mathrm{~d},{ }^{6} J_{\mathrm{CP}}=3 \mathrm{~Hz}, \mathrm{Me}-\mathrm{Xyl}\right) \mathrm{ppm}$. ${ }^{31} \mathrm{P}\left\{{ }^{1} \mathrm{H}\right\} \mathrm{NMR}\left(161.9 \mathrm{MHz}, 25{ }^{\circ} \mathrm{C}, \mathrm{CDCl}_{3}\right): \delta-19.0$ (s) ppm. L3·Se. ${ }^{31} \mathrm{P}\left\{{ }^{1} \mathrm{H}\right\} \mathrm{NMR}(161.9 \mathrm{MHz}$, $\left.25{ }^{\circ} \mathrm{C}, \mathrm{C}_{6} \mathrm{D}_{6}\right): \delta 21.9\left({ }^{1} J_{\mathrm{PSe}}=733 \mathrm{~Hz}\right) \mathrm{ppm}$.

$\mathbf{P}\left(\mathbf{C}_{4} \mathbf{H}_{7}\right)_{2} \mathbf{A r}^{\mathbf{X y l}_{2}}$, L4. Yield: $0.60 \mathrm{~g}, 55 \% .{ }^{1} \mathrm{H}$ NMR $\left(\mathrm{CDCl}_{3}, 400.1 \mathrm{~Hz}, 298 \mathrm{~K}\right): \delta 7.40(\mathrm{t}, 1 \mathrm{H}$, $\left.{ }^{3} J_{\mathrm{HH}}=7.4 \mathrm{~Hz}, p-\mathrm{C}_{6} \mathrm{H}_{3}\right), 7.19\left(\mathrm{t}, 2 \mathrm{H},{ }^{3} J_{\mathrm{HH}}=7.5 \mathrm{~Hz}, p-\mathrm{Xyl}\right), 7.09\left(\mathrm{~d}, 4 \mathrm{H},{ }^{3} J_{\mathrm{HH}}=7.5 \mathrm{~Hz}, m-\mathrm{Xyl}\right)$, $6.99\left(\mathrm{dd}, 2 \mathrm{H},{ }^{3} \mathrm{~J}_{\mathrm{HH}}=7.4 \mathrm{~Hz},{ }^{4} \mathrm{~J}_{\mathrm{HP}}=1.4 \mathrm{~Hz}, m-\mathrm{C}_{6} \mathrm{H}_{3}\right), 5.62\left(\mathrm{~m}, 2 \mathrm{H}, \mathrm{CH}=\mathrm{CH}_{2}\right), 4.85-4.75(\mathrm{~m}, 4 \mathrm{H}$, $\left.\mathrm{CH}=\mathrm{CH}_{2}\right), 2.07\left(\mathrm{~s}, 12 \mathrm{H}, \mathrm{CH}_{3}\right), 1.80\left(\mathrm{~m}, 4 \mathrm{H}, \mathrm{PCH}_{2} \mathrm{CH}_{2}\right), 1.40-1.29(\mathrm{~m}, 2 \mathrm{H}, \mathrm{PCHH}), 1.18-1.06$ (m, 2H, PCHH) ppm. ${ }^{13} \mathrm{C}\left\{{ }^{1} \mathrm{H}\right\} \mathrm{NMR}\left(\mathrm{CDCl}_{3}, 125.76 \mathrm{~Hz}, 298 \mathrm{~K}\right): \delta 147.2\left(\mathrm{~d},{ }^{2} J_{\mathrm{CP}}=15.4 \mathrm{~Hz}, o-\right.$ $\left.\mathrm{C}_{6} \mathrm{H}_{3}\right), 142.5\left(\mathrm{~d},{ }^{3} J_{\mathrm{CP}}=4.5 \mathrm{~Hz}\right.$, ipso-Xyl), $139.2\left(\mathrm{~d},{ }^{3} J_{\mathrm{CP}}=16.4 \mathrm{~Hz}, C \mathrm{H}=\mathrm{CH}_{2}\right), 136.1$ (s, o-Xyl), $135.2\left(\mathrm{~d},{ }^{1} J_{\mathrm{CP}}=28.0 \mathrm{~Hz}\right.$, ipso- $\left.\mathrm{C}_{6} \mathrm{H}_{3}\right), 129.6\left(\mathrm{~d},{ }^{3} J_{\mathrm{CP}}=2.6 \mathrm{~Hz}, m-\mathrm{C}_{6} \mathrm{H}_{3}\right), 129.0\left(\mathrm{~s}, p-\mathrm{C}_{6} \mathrm{H}_{3}\right), 127.2$ (s, $p$-Xyl), $127.1(\mathrm{~s}, m-\mathrm{Xyl}), 113.7\left(\mathrm{~s}, \mathrm{CH}=C \mathrm{H}_{2}\right), 31.9\left(\mathrm{~d},{ }^{2} J_{\mathrm{CP}}=25.4 \mathrm{~Hz}, \mathrm{PCH}_{2} \mathrm{CH}_{2}\right), 25.8$ (d, $\left.{ }^{1} J_{\mathrm{CP}}=15.1 \mathrm{~Hz}, \mathrm{PCH}_{2} \mathrm{CH}_{2}\right), 21.3\left(\mathrm{~d},{ }^{5} J_{\mathrm{CP}}=2.3 \mathrm{~Hz}, \mathrm{CH}_{3}\right) \mathrm{ppm} .{ }^{31} \mathrm{P}\left\{{ }^{1} \mathrm{H}\right\} \mathrm{NMR}\left(\mathrm{CDCl}_{3}, 161.96\right.$ MHz, $298 \mathrm{~K}): \delta-17.1$ (s) ppm. L4·Se. ${ }^{31} \mathrm{P}\left\{{ }^{1} \mathrm{H}\right\}$ NMR $\left(161.9 \mathrm{MHz}, 25{ }^{\circ} \mathrm{C}, \mathrm{C}_{6} \mathrm{D}_{6}\right): \delta 31.1\left({ }^{1} J_{\mathrm{PSe}}\right.$ $=721 \mathrm{~Hz}) \mathrm{ppm}$.

$\mathbf{P E t}_{2} \mathbf{A r}^{\text {Dipp }_{2}}$, L6. Yield: 0.08 g, $41 \%$. HR-MS (ESI) $\mathrm{m} / z$ Calcd. for $[\mathrm{M}+\mathrm{H}]^{+}$: 487.35. Expt.: 487.35. ${ }^{1} \mathrm{H}$ NMR $\left(400 \mathrm{MHz}, 25{ }^{\circ} \mathrm{C}, \mathrm{CDCl}_{3}\right): \delta 7.35$ (t, $2 \mathrm{H},{ }^{3} \mathrm{~J}_{\mathrm{HH}}=7.8 \mathrm{~Hz}, p$-Dipp), $7.28(\mathrm{t}, 1 \mathrm{H}$, $\left.{ }^{3} J_{\mathrm{HH}}=7.5 \mathrm{~Hz}, p-\mathrm{C}_{6} \mathrm{H}_{3}\right), 7.19\left(\mathrm{~d}, 4 \mathrm{H},{ }^{3} J_{\mathrm{HH}}=7.8 \mathrm{~Hz}, m\right.$-Dipp), $7.04\left(\mathrm{~d}, 2 \mathrm{H},{ }^{3} J_{\mathrm{HH}}=7.5 \mathrm{~Hz}, m-\right.$ $\left.\mathrm{C}_{6} \mathrm{H}_{3}\right), 2.65$ (sept, $\left.4 \mathrm{H},{ }^{3} J_{\mathrm{HH}}=7.5 \mathrm{~Hz}, \mathrm{CH}-\mathrm{Dipp}\right), 1.25$ (d, $12 \mathrm{H},{ }^{3} J_{\mathrm{HH}}=6.8 \mathrm{~Hz}$, Me-Dipp), 1.21 $\left(\mathrm{m}, 2 \mathrm{H}, \mathrm{CH}_{2}\right), 1.10\left(\mathrm{~m}, 2 \mathrm{H}, \mathrm{CH}_{2}\right), 1.03\left(\mathrm{~d}, 12 \mathrm{H},{ }^{3} J_{\mathrm{HH}}=6.4 \mathrm{~Hz}, \mathrm{Me}-\mathrm{Dipp}\right), 0.74\left(\mathrm{dt}, 6 \mathrm{H},{ }^{3} J_{\mathrm{HP}}=\right.$ 
$\left.16.8 \mathrm{~Hz},{ }^{3} J_{\mathrm{HH}}=7.5 \mathrm{~Hz}, \mathrm{CH}_{3}-\mathrm{Et}\right) \mathrm{ppm} .{ }^{13} \mathrm{C}\left\{{ }^{1} \mathrm{H}\right\} \mathrm{NMR}\left(100.57 \mathrm{MHz}, 2{ }^{\circ} \mathrm{C}, \mathrm{CDCl}_{3}\right): \delta 146.7(\mathrm{~s}$, $o$-Dipp), $145.7\left(\mathrm{~d},{ }^{2} J_{\mathrm{CP}}=15 \mathrm{~Hz}, o-\mathrm{C}_{6} \mathrm{H}_{3}\right), 140.5\left(\mathrm{~d},{ }^{3} J_{\mathrm{CP}}=5 \mathrm{~Hz}, \mathrm{C}_{\mathrm{ipso}}-\mathrm{Dipp}\right), 137.6\left(\mathrm{~d},{ }^{1} J_{\mathrm{CP}}=27.5\right.$ $\mathrm{Hz}, \mathrm{C}_{\mathrm{ipso}}-\mathrm{C}_{6} \mathrm{H}_{3}$ ), 131.0 (s, $m$ - $\mathrm{C}_{6} \mathrm{H}_{3}$ ), 128.0 (s, $p$-Dipp), 126.7 (s, $p$ - $\mathrm{C}_{6} \mathrm{H}_{3}$ ), 122.5 (s, $m$-Dipp), 31.1 (s, CH-Dipp), 25.9 (s, Me-Dipp), 22.6 (s, Me-Dipp), 18.8 (d, $\left.{ }^{1} J_{\mathrm{CP}}=13.6 \mathrm{~Hz}, \mathrm{CH}_{2}\right), 12.0$ (d, ${ }^{2} J_{\mathrm{CP}}$ $=22.3 \mathrm{~Hz}, \mathrm{CH}_{3}$-Et) ppm. ${ }^{31} \mathrm{P}\left\{{ }^{1} \mathrm{H}\right\}$ NMR $\left(161.9 \mathrm{MHz}, 25{ }^{\circ} \mathrm{C}, \mathrm{CDCl}_{3}\right): \delta-9.3$ (s) ppm. L6.Se. ${ }^{31} \mathrm{P}\left\{{ }^{1} \mathrm{H}\right\}$ NMR $\left(161.9 \mathrm{MHz}, 25^{\circ} \mathrm{C}, \mathrm{C}_{6} \mathrm{D}_{6}\right): \delta 39.2\left({ }^{1} J_{\mathrm{PSe}}=722 \mathrm{~Hz}\right) \mathrm{ppm}$.

$\mathbf{P}\left(\mathbf{C}_{3} \mathbf{H}_{5}\right)_{2} \mathbf{A r}^{\text {Dipp }_{2}}$, L7. Yield: $0.50 \mathrm{~g}, 60 \%$. Anal. Calc. for $\mathrm{C}_{36} \mathrm{H}_{47} \mathrm{P}: \mathrm{C}, 84.66 ; \mathrm{H}, 9.28$. Found: C, 84.4; H, 9.3. ${ }^{1} \mathrm{H}$ NMR $\left(400 \mathrm{MHz}, 2{ }^{\circ} \mathrm{C}, \mathrm{CDCl}_{3}\right): \delta 7.35$ (t, $2 \mathrm{H},{ }^{3} J_{\mathrm{HH}}=7.7 \mathrm{~Hz}, p$-Dipp), $7.29(\mathrm{t}$, $\left.1 \mathrm{H},{ }^{3} J_{\mathrm{HH}}=7.6 \mathrm{~Hz}, p-\mathrm{C}_{6} \mathrm{H}_{3}\right), 7.19\left(\mathrm{~d}, 4 \mathrm{H},{ }^{3} J_{\mathrm{HH}}=7.7 \mathrm{~Hz}, m\right.$-Dipp), $7.05\left(\mathrm{dd}, 2 \mathrm{H},{ }^{3} J_{\mathrm{HH}}=7.6 \mathrm{~Hz}\right.$, $\left.{ }^{4} J_{\mathrm{HP}}=2.2 \mathrm{~Hz}, m-\mathrm{C}_{6} \mathrm{H}_{3}\right), 5.35\left(\mathrm{~m}, 2 \mathrm{H}, \mathrm{PCH}_{2} \mathrm{CHCH}_{2}\right), 4.77\left(\mathrm{~m}, 2 \mathrm{H}, \mathrm{PCH}_{2} \mathrm{CHCH}_{2}\right), 4.69(\mathrm{~m}, 2 \mathrm{H}$, $\mathrm{PCH}_{2} \mathrm{CHCH}_{2}$ ), 2.69 (sept, $\left.4 \mathrm{H},{ }^{3} J_{\mathrm{HH}}=6.8 \mathrm{~Hz}, \mathrm{CH}-\mathrm{Dipp}\right), 2.04\left(\mathrm{~m}, 2 \mathrm{H}, \mathrm{PCH}_{2} \mathrm{CHCH}_{2}\right), 1.85(\mathrm{~m}$, $\left.2 \mathrm{H}, \mathrm{PCH}_{2} \mathrm{CHCH}_{2}\right), 1.27(\mathrm{~d}, 12 \mathrm{H}, 3 \mathrm{JHH}=6.9 \mathrm{~Hz}, \mathrm{Me}-\mathrm{Dipp}), 1.04\left(\mathrm{~d}, 12 \mathrm{H},{ }^{3} J_{\mathrm{HH}}=6.7 \mathrm{~Hz}\right.$, Me-Dipp) ppm. ${ }^{13} \mathrm{C}\left\{{ }^{1} \mathrm{H}\right\}$ NMR $\left(100.57 \mathrm{MHz}, 25^{\circ} \mathrm{C}, \mathrm{CDCl}_{3}\right): \delta 146.8$ (s, o-Dipp), $145.0\left(\mathrm{~d},{ }^{2} J_{\mathrm{CP}}\right.$ $\left.=14 \mathrm{~Hz}, o-\mathrm{C}_{6} \mathrm{H}_{3}\right), 140.0\left(\mathrm{~d},{ }^{3} J_{\mathrm{CP}}=4 \mathrm{~Hz}, \mathrm{C}_{\mathrm{ipso}}-\mathrm{Dipp}\right), 136.9\left(\mathrm{~d},{ }^{1} J_{\mathrm{CP}}=34 \mathrm{~Hz}, \mathrm{C}_{\mathrm{ipso}}-\mathrm{C}_{6} \mathrm{H}_{3}\right), 135.0$ $\left(\mathrm{d},{ }^{2} J_{\mathrm{CP}}=11 \mathrm{~Hz}, \mathrm{PCH}_{2} \mathrm{CHCH}_{2}\right), 131.1\left(\mathrm{~d},{ }^{3} J_{\mathrm{CP}}=1 \mathrm{~Hz}, m-\mathrm{C}_{6} \mathrm{H}_{3}\right), 128.4$ (s, $p$-Dipp), 126.7 (s, $p$ $\mathrm{C}_{6} \mathrm{H}_{3}$ ), 122.8 (s, $m$-Dipp), $116.4\left(\mathrm{~d},{ }^{3} J_{\mathrm{CP}}=9 \mathrm{~Hz}, \mathrm{PCH}_{2} \mathrm{CHCH}_{2}\right), 31.0$ (d, $\left.{ }^{5} J_{\mathrm{CP}}=1 \mathrm{~Hz}, \mathrm{CH}-\mathrm{Dipp}\right)$, $30.3\left(\mathrm{~d},{ }^{1} J_{\mathrm{CP}}=18 \mathrm{~Hz}, \mathrm{PCH}_{2} \mathrm{CHCH}_{2}\right.$ ), 25.9 (s, Me-Dipp), 22.7 (d, $\left.{ }^{7} J_{\mathrm{CP}}=2 \mathrm{~Hz}, \mathrm{Me}-\mathrm{Dipp}\right)$ ppm. ${ }^{31} \mathrm{P}\left\{{ }^{1} \mathrm{H}\right\} \mathrm{NMR}\left(161.9 \mathrm{MHz}, 25{ }^{\circ} \mathrm{C}, \mathrm{CDCl}_{3}\right): \delta-20.0$ (s) ppm. L7•Se. ${ }^{31} \mathrm{P}\left\{{ }^{1} \mathrm{H}\right\} \mathrm{NMR}(161.9 \mathrm{MHz}$, $\left.25^{\circ} \mathrm{C}, \mathrm{C}_{6} \mathrm{D}_{6}\right): \delta 22.8\left({ }^{1} J_{\mathrm{PSe}}=737 \mathrm{~Hz}\right) \mathrm{ppm}$.

$\mathbf{P M e}_{2} \mathrm{Ar}^{\mathrm{Tipp}_{2}}$, L8. Yield: $13.2 \mathrm{~g}, 54 \%$. Anal. Calc. for $\mathrm{C}_{38} \mathrm{H}_{55} \mathrm{P}: \mathrm{C}, 84.0 ; \mathrm{H}, 10.2$. Found: C, 84.4; $\mathrm{H}, 10.4 .{ }^{1} \mathrm{H}$ NMR $\left(300 \mathrm{MHz}, 25{ }^{\circ} \mathrm{C}, \mathrm{CDCl}_{3}\right): \delta 7.23\left(\mathrm{t}, 1 \mathrm{H},{ }^{3} J_{\mathrm{HH}}=7.6 \mathrm{~Hz}, p-\mathrm{C}_{6} \mathrm{H}_{3}\right), 7.02(\mathrm{dd}, 2$ $\left.\mathrm{H},{ }^{3} J_{\mathrm{HH}}=7.6 \mathrm{~Hz},{ }^{4} J_{\mathrm{HP}}=1.5 \mathrm{~Hz}, m-\mathrm{C}_{6} \mathrm{H}_{3}\right), 6.99$ (s, $4 \mathrm{H}, m$-Tipp), 2.91 (sept, $2 \mathrm{H},{ }^{3} J_{\mathrm{HH}}=6.7 \mathrm{~Hz}$, $p$-CH-Trip), 2.64 (sept, $4 \mathrm{H},{ }^{3} \mathrm{~J}_{\mathrm{HH}}=6.6 \mathrm{~Hz}, o$-CH-Tipp), 1.27 (d, $12 \mathrm{H},{ }^{3} J_{\mathrm{HH}}=7.0 \mathrm{~Hz}, p$-MeTipp), $1.22\left(\mathrm{~d}, 12 \mathrm{H},{ }^{3} J_{\mathrm{HH}}=6.9 \mathrm{~Hz}, o\right.$-Me-Tipp), $1.02\left(\mathrm{~d}, 12 \mathrm{H},{ }^{3} J_{\mathrm{HH}}=6.8 \mathrm{~Hz}, o\right.$-Me-Tipp), 0.63 $\left(\mathrm{d}, 6 \mathrm{H},{ }^{2} J_{\mathrm{HP}}=4.6 \mathrm{~Hz}, \mathrm{PMe}_{2}\right) \mathrm{ppm} .{ }^{13} \mathrm{C}\left\{{ }^{1} \mathrm{H}\right\} \mathrm{NMR}\left(125 \mathrm{MHz}, 25{ }^{\circ} \mathrm{C}, \mathrm{CD}_{2} \mathrm{Cl}_{2}\right): \delta 148.0(\mathrm{~s}, \mathrm{p}-$ Trip), 146.1 (s, o-Tipp), $144.7\left(\mathrm{~d},{ }^{1} J_{\mathrm{CP}}=15 \mathrm{~Hz}, o-\mathrm{C}_{6} \mathrm{H}_{3}\right), 138.6\left(\mathrm{~d},{ }^{1} J_{\mathrm{CP}}=27 \mathrm{~Hz}, \mathrm{C}_{\mathrm{ipso}}-\mathrm{C}_{6} \mathrm{H}_{3}\right.$ ), $137.4\left(\mathrm{~d},{ }^{3} J_{\mathrm{CP}}=4 \mathrm{~Hz}, \mathrm{C}_{\mathrm{ipso}}\right.$-Tipp), $130.8\left(\mathrm{~s}, m-\mathrm{C}_{6} \mathrm{H}_{3}\right), 126.3$ (s, $\left.p-\mathrm{C}_{6} \mathrm{H}_{3}\right), 120.4$ (s, $m$-Tipp), 34.2 (s, $p$-CH-Tipp), 30.8 (s, o-CH-Tipp), 25.7 (s, o-Me-Tipp), 24.2 (s, $p$-Me-Tipp), 22.6 (s, o-MeTipp), $13.5\left(\mathrm{~d},{ }^{3} J_{\mathrm{HP}}=14 \mathrm{~Hz}, \mathrm{PMe}_{2}\right) \mathrm{ppm} .{ }^{31} \mathrm{P}\left\{{ }^{1} \mathrm{H}\right\} \mathrm{NMR}\left(160 \mathrm{MHz}, 25{ }^{\circ} \mathrm{C}, \mathrm{CD}_{2} \mathrm{Cl}_{2}\right): \delta-40.7(\mathrm{~s})$ ppm. L8·Se. ${ }^{31} \mathrm{P}\left\{{ }^{1} \mathrm{H}\right\} \mathrm{NMR}\left(161.9 \mathrm{MHz}, 25^{\circ} \mathrm{C}, \mathrm{C}_{6} \mathrm{D}_{6}\right): \delta 12.5\left({ }^{1} J_{\mathrm{PSe}}=703 \mathrm{~Hz}\right) \mathrm{ppm}$.

$\mathbf{P E t}_{2} \mathbf{A r}^{\mathrm{Mes}_{2}}$, L9. Yield: 0.64 g, 43\%. HR-MS (ESI) $\mathrm{m} / z$ Calcd. for $[\mathrm{M}+\mathrm{H}]^{+}: 403.25$ Expt.: 403.25. ${ }^{1} \mathrm{H}$ NMR (400 MHz, $\left.25{ }^{\circ} \mathrm{C}, \mathrm{CDCl}_{3}\right): \delta 7.36\left(\mathrm{t}, 1 \mathrm{H},{ }^{3} \mathrm{~J}_{\mathrm{HH}}=7.5 \mathrm{~Hz}, p-\mathrm{C}_{6} \mathrm{H}_{3}\right), 6.94(\mathrm{dd}, 2$ $\left.\mathrm{H},{ }^{3} J_{\mathrm{HH}}=7.5 \mathrm{~Hz},{ }^{4} J_{\mathrm{HP}}=1.9 \mathrm{~Hz}, m-\mathrm{C}_{6} \mathrm{H}_{3}\right), 6.91(\mathrm{~s}, 4 \mathrm{H}, m-\mathrm{Mes}), 2.34$ (s, $6 \mathrm{H}, p$-Me-Mes), 2.03 (s, $12 \mathrm{H}, o$-Me-Mes), $1.26\left(\mathrm{dq}, 2 \mathrm{H},{ }^{3} J_{\mathrm{HH}}=7.7 \mathrm{~Hz},{ }^{2} J_{\mathrm{HP}}=1.7 \mathrm{~Hz}, \mathrm{CH}_{2}-\mathrm{Et}\right), 1.09\left(\mathrm{dq}, 2 \mathrm{H},{ }^{3} J_{\mathrm{HH}}=\right.$ $\left.7.5 \mathrm{~Hz},{ }^{2} J_{\mathrm{HP}}=1.5 \mathrm{~Hz}, \mathrm{CH}_{2}-\mathrm{Et}\right), 0.78\left(\mathrm{dt}, 6 \mathrm{H},{ }^{3} J_{\mathrm{HH}}=7.6 \mathrm{~Hz},{ }^{3} J_{\mathrm{HP}}=16.7 \mathrm{~Hz}, \mathrm{CH}_{3}-\mathrm{Et}\right) \mathrm{ppm}$. ${ }^{13} \mathrm{C}\left\{{ }^{1} \mathrm{H}\right\} \mathrm{NMR}\left(100.57 \mathrm{MHz}, 25{ }^{\circ} \mathrm{C}, \mathrm{CDCl}_{3}\right): \delta 147.5\left(\mathrm{~d},{ }^{2} J_{\mathrm{CP}}=15 \mathrm{~Hz}, o-\mathrm{C}_{6} \mathrm{H}_{3}\right), 140.0\left(\mathrm{~d},{ }^{3} J_{\mathrm{CP}}=\right.$ $5 \mathrm{~Hz}, \mathrm{C}_{\mathrm{ipso}}-\mathrm{Mes}$ ), 136.6 (s, o-Mes), 136.1 (s, $p$-Mes), 129.9 (d, ${ }^{3} J_{\mathrm{CP}}=3 \mathrm{~Hz}, m-\mathrm{C}_{6} \mathrm{H}_{3}$ ), 128.0 (s, $m$-Mes), 21.3 (s, o-Me-Mes), 21.3 (s, $p$-Me-Mes), 18.5 (d, ${ }^{1} J_{\mathrm{CP}}=13 \mathrm{~Hz}, \mathrm{CH}_{2}$-Et), 12.21 (d, ${ }^{2} J_{\mathrm{CP}}$ $=22 \mathrm{~Hz}, \mathrm{CH}_{3}$-Et) ppm. ${ }^{31} \mathrm{P}\left\{{ }^{1} \mathrm{H}\right\} \mathrm{NMR}\left(161.9 \mathrm{MHz}, 25{ }^{\circ} \mathrm{C}, \mathrm{CDCl}_{3}\right): \delta-8.3$ (s) ppm. L9・Se. ${ }^{31} \mathrm{P}\left\{{ }^{1} \mathrm{H}\right\}$ NMR $\left(161.9 \mathrm{MHz}, 25{ }^{\circ} \mathrm{C}, \mathrm{C}_{6} \mathrm{D}_{6}\right): \delta 36.9\left({ }^{1} J_{\mathrm{PSe}}=715 \mathrm{~Hz}\right) \mathrm{ppm}$.

$\mathbf{P}(\mathbf{C C H})_{2} \mathbf{A r}^{\mathrm{Mes}_{2}}$, L10. Yield: 0.65 g, $44 \%$. Anal. Calc. for $\mathrm{C}_{28} \mathrm{H}_{27} \mathrm{P}: \mathrm{C}, 85.25$; H, 6.90. Found: $\mathrm{C}, 85.3 ; \mathrm{H}, 7.3 .{ }^{1} \mathrm{H}$ NMR $\left(400 \mathrm{MHz}, 25^{\circ} \mathrm{C}, \mathrm{CDCl}_{3}\right): \delta 7.52\left(\mathrm{t}, 1 \mathrm{H},{ }^{3} J_{\mathrm{HH}}=7.6 \mathrm{~Hz}, p-\mathrm{C}_{6} \mathrm{H}_{3}\right), 7.10$ $\left(\mathrm{dd}, 2 \mathrm{H},{ }^{3} J_{\mathrm{HH}}=7.5 \mathrm{~Hz},{ }^{4} J_{\mathrm{HP}}=2.9 \mathrm{~Hz}, m-\mathrm{C}_{6} \mathrm{H}_{3}\right), 6.89(\mathrm{~s}, 4 \mathrm{H}, m-\mathrm{Mes}), 2.70(\mathrm{~s}, 2 \mathrm{H}, \mathrm{PCCH}), 2.34$ 
(s, $6 \mathrm{H}, p$-Me-Mes), 2.04 (s, $12 \mathrm{H}, o$-Me-Mes) ppm. ${ }^{13} \mathrm{C}\left\{{ }^{1} \mathrm{H}\right\}$ NMR $\left(100.57 \mathrm{MHz}, 25{ }^{\circ} \mathrm{C}\right.$, $\left.\mathrm{CDCl}_{3}\right): \delta 147.3\left(\mathrm{~d},{ }^{2} J_{\mathrm{CP}}=21 \mathrm{~Hz}, o-\mathrm{C}_{6} \mathrm{H}_{3}\right), 141.4\left(\mathrm{~d},{ }^{1} J_{\mathrm{CP}}=40 \mathrm{~Hz}, \mathrm{C}_{\mathrm{ipso}}-\mathrm{C}_{6} \mathrm{H}_{3}\right), 138.4\left(\mathrm{~d},{ }^{3} J_{\mathrm{CP}}=6\right.$ $\mathrm{Hz}, \mathrm{C}_{\mathrm{ipso}}-\mathrm{Mes}$ ), 137.5 (s, $p$-Mes), 136.8 (s, o-Mes), 131.2 (s, $\left.p-\mathrm{C}_{6} \mathrm{H}_{3}\right), 130.0$ (d, ${ }^{4} J_{\mathrm{CP}}=4 \mathrm{~Hz}, m$ $\left.\mathrm{C}_{6} \mathrm{H}_{3}\right), 127.9$ (s, $m$-Mes), $95.4\left(\mathrm{~d},{ }^{2} J_{\mathrm{CP}}=10 \mathrm{~Hz}, \mathrm{PCCH}\right), 77.6\left(\mathrm{~d},{ }^{1} J_{\mathrm{CP}}=18 \mathrm{~Hz}, \mathrm{PCCH}\right), 21.4(\mathrm{~s}$, p-Me-Mes), 21.3 (s, o-Me-Mes) ppm. ${ }^{31} \mathrm{P}\left\{{ }^{1} \mathrm{H}\right\} \mathrm{NMR}\left(161.9 \mathrm{MHz}, 25{ }^{\circ} \mathrm{C}, \mathrm{CDCl}_{3}\right.$ ): $\delta-74.3$ (s) ppm.

$\mathbf{P M e}_{2} \mathbf{A r}^{\mathbf{P h}_{2}}$, L11. Yield: $1.63 \mathrm{~g}, 80 \%$. Anal. Calc. for $\mathrm{C}_{20} \mathrm{H}_{19} \mathrm{P}: \mathrm{C}, 82.74 ; \mathrm{H}, 6.60$. Found: $\mathrm{C}$, 82.5; H, 6.9. ${ }^{1} \mathrm{H}$ NMR $\left(400 \mathrm{MHz}, 25^{\circ} \mathrm{C}, \mathrm{CDCl}_{3}\right): \delta 0.71\left(\mathrm{~d}, 6 \mathrm{H},{ }^{2} J_{\mathrm{HP}}=4.4 \mathrm{~Hz}, \mathrm{PMe}_{2}\right), 7.20-7.50$ $\left(\mathrm{m}, 13 \mathrm{H}, \mathrm{CH}_{\mathrm{Ar}}\right) \mathrm{ppm} .{ }^{13} \mathrm{C}\left\{{ }^{1} \mathrm{H}\right\} \mathrm{NMR}\left(125 \mathrm{MHz}, 25^{\circ} \mathrm{C}, \mathrm{CD}_{2} \mathrm{Cl}_{2}\right): \delta 148.0\left(\mathrm{~d},{ }^{2} J_{\mathrm{CP}}=11 \mathrm{~Hz}, o-\right.$ $\left.\mathrm{C}_{6} \mathrm{H}_{3}\right), 143.7\left(\mathrm{~d},{ }^{3} J_{\mathrm{CP}}=3 \mathrm{~Hz}, \mathrm{C}_{\mathrm{ipso}}-\mathrm{C}_{6} \mathrm{H}_{5}\right), 139.3\left(\mathrm{~d},{ }^{1} J_{\mathrm{CP}}=31 \mathrm{~Hz}, \mathrm{C}_{\mathrm{ipso}}-\mathrm{C}_{6} \mathrm{H}_{3}\right), 129.9\left(\mathrm{~s}, \mathrm{CH}_{\mathrm{Ar}}\right)$, $129.7\left(\mathrm{~d}, J_{\mathrm{CP}}=3 \mathrm{~Hz}, \mathrm{CH}_{\mathrm{Ar}}\right), 128.2\left(\mathrm{~s}, \mathrm{CH}_{\mathrm{Ar}}\right), 127.3\left(\mathrm{~s}, \mathrm{CH}_{\mathrm{Ar}}\right), 127.1\left(\mathrm{~s}, \mathrm{CH}_{\mathrm{Ar}}\right), 15.6\left(\mathrm{~d},{ }^{1} J_{\mathrm{CP}}=14\right.$ $\mathrm{Hz}, \mathrm{PMe}_{2}$ ) ppm. ${ }^{31} \mathrm{P}\left\{{ }^{1} \mathrm{H}\right\}$ NMR $\left(160 \mathrm{MHz}, 25{ }^{\circ} \mathrm{C}, \mathrm{CD}_{2} \mathrm{Cl}_{2}\right): \delta-35.8(\mathrm{~s})$ ppm. L2 $\cdot$ Se. ${ }^{31} \mathrm{P}\left\{{ }^{1} \mathrm{H}\right\}$ NMR $\left(161.9 \mathrm{MHz}, 25^{\circ} \mathrm{C}, \mathrm{C}_{6} \mathrm{D}_{6}\right): \delta 10.7\left({ }^{1} J_{\mathrm{PSe}}=713 \mathrm{~Hz}\right) \mathrm{ppm}$.

Phosphine oxidation reactions. To ascertain the reactivity of the $\mathrm{PMe}_{2} \mathrm{Ar}$ ' ligands towards air in the solid state, a sample of $c a .30 \mathrm{mg}$ of the phosphine, in the form of finely divided powder, was placed in a vial open to the atmosphere and kept at room temperature for a week, with periodical examination of the content by solution ${ }^{31} \mathrm{P}\left\{{ }^{1} \mathrm{H}\right\}$ NMR spectroscopy. Toluene solutions of the phosphines were similarly kept at $25^{\circ} \mathrm{C}$, under air, and monitored by NMR. For the high temperature $\left(100{ }^{\circ} \mathrm{C}\right)$ oxidations, the toluene solutions were prepared at room temperature under air, and were then heated in a closed flask. Progress of the reactions was once more followed by ${ }^{31} \mathrm{P}\left\{{ }^{1} \mathrm{H}\right\}$ NMR spectroscopy.

[RhCl(COD) $\left.\left(\mathbf{P M e}_{2} \mathbf{A r}^{\mathrm{Xyl}}\right)\right], \mathbf{1} \cdot \mathbf{L 1}$. A solid mixture of $[\mathrm{RhCl}(\mathrm{COD})]_{2}(0.2 \mathrm{mmol})$ and ligand $\mathbf{L 1}$ (0.4 mmol) was dissolved in $\mathrm{CH}_{2} \mathrm{Cl}_{2}(6 \mathrm{~mL})$ and stirred for 3 hours at room temperature. The solvent was evaporated under reduced pressure to obtain complex $\mathbf{1} \cdot \mathbf{L 1}$ as a yellow solid (Yield: $214 \mathrm{mg}, 90 \%$ \%). Anal. Calc. for $\mathrm{C}_{32} \mathrm{H}_{39} \mathrm{ClPRh}$ : C, 64.8; H, 6.6. Found: C, 64.7; H, 7.0. ${ }^{1} \mathrm{H}$ NMR $\left(300 \mathrm{MHz}, 25{ }^{\circ} \mathrm{C}, \mathrm{CD}_{2} \mathrm{Cl}_{2}\right): \delta 7.51\left(\mathrm{td}, 1 \mathrm{H},{ }^{3} J_{\mathrm{HH}}=7.6 \mathrm{~Hz},{ }^{5} J_{\mathrm{HP}}=1.7 \mathrm{~Hz}, p-\mathrm{C}_{6} \mathrm{H}_{3}\right), 7.26(\mathrm{t}, 2 \mathrm{H}$, $\left.{ }^{3} J_{\mathrm{HH}}=7.6 \mathrm{~Hz}, p-\mathrm{Xyl}\right), 7.19\left(\mathrm{~d}, 4 \mathrm{H},{ }^{3} J_{\mathrm{HH}}=7.6 \mathrm{~Hz}, m-\mathrm{Xyl}\right), 6.99\left(\mathrm{dd}, 2 \mathrm{H},{ }^{3} J_{\mathrm{HH}}=7.6 \mathrm{~Hz},{ }^{4} J_{\mathrm{HP}}=\right.$ $2.7 \mathrm{~Hz}, m-\mathrm{C}_{6} \mathrm{H}_{3}$ ), 5.04 (br s, $2 \mathrm{H}, \mathrm{CH}-\mathrm{COD}$ ), 2.62 (br s, $2 \mathrm{H}, \mathrm{CH}-\mathrm{COD}$ ) 2.33, 2.16, 1.76 (m, 1:1:2 ratio $\left.8 \mathrm{H}, 4 \mathrm{CH}_{2}\right), 2.28(\mathrm{~s}, 12 \mathrm{H}, \mathrm{Me}-\mathrm{Xyl}), 1.04\left(\mathrm{dd}, 6 \mathrm{H},{ }^{2} J_{\mathrm{HP}}=7.9 \mathrm{~Hz},{ }^{3} J_{\mathrm{HRh}}=0.9 \mathrm{~Hz}\right.$, $\left.\mathrm{PMe}_{2}\right)$ ppm. ${ }^{13} \mathrm{C}\left\{{ }^{1} \mathrm{H}\right\}$ NMR $\left(75 \mathrm{MHz}, 25{ }^{\circ} \mathrm{C}, \mathrm{CD}_{2} \mathrm{Cl}_{2}\right): \delta 146.3\left(\mathrm{~d},{ }^{2} J_{\mathrm{CP}}=9 \mathrm{~Hz}, o-\mathrm{C}_{6} \mathrm{H}_{3}\right), 142.2$ $\left(\mathrm{d},{ }^{3} J_{\mathrm{CP}}=4 \mathrm{~Hz}\right.$, ipso-Xyl), $137.4(\mathrm{~s}, o-\mathrm{Xyl}), 130.9\left(\mathrm{~d},{ }^{3} J_{\mathrm{CP}}=7 \mathrm{~Hz}, m-\mathrm{C}_{6} \mathrm{H}_{3}\right), 130.6\left(\mathrm{~d},{ }^{1} J_{\mathrm{CP}}=35\right.$ $\mathrm{Hz}$, ipso- $\left.\mathrm{C}_{6} \mathrm{H}_{3}\right), 130.2\left(\mathrm{~d},{ }^{4} J_{\mathrm{CP}}=2 \mathrm{~Hz}, \mathrm{C} p-\mathrm{C}_{6} \mathrm{H}_{3}\right), 128.1$ (s, p-Xyl), 127.9 (s, CH-COD), 101.1 $\left(\mathrm{dd},{ }^{1} J_{\mathrm{CRh}}=14 \mathrm{~Hz},{ }^{2} J_{\mathrm{CP}}=8 \mathrm{~Hz}, \mathrm{CH}-\mathrm{COD}\right), 69.2\left(\mathrm{~d},{ }^{1} J_{\mathrm{CRh}}=14 \mathrm{~Hz}, \mathrm{CH}-\mathrm{COD}\right), 33.5,28.6(\mathrm{~d}$, $\left.{ }^{2} J_{\mathrm{CRh}}=2 \mathrm{~Hz}, \mathrm{CH}_{2}-\mathrm{COD}\right), 22.4(\mathrm{~s}, \mathrm{Me}-\mathrm{Xyl}), 13.2\left(\mathrm{~d},{ }^{1} J_{\mathrm{CP}}=25 \mathrm{~Hz}, \mathrm{PMe}_{2}\right) \mathrm{ppm} .{ }^{31} \mathrm{P}\left\{{ }^{1} \mathrm{H}\right\} \mathrm{NMR}$ $\left(120 \mathrm{MHz}, 25^{\circ} \mathrm{C}, \mathrm{CD}_{2} \mathrm{Cl}_{2}\right): \delta-5.1\left(\mathrm{~d},{ }^{1} J_{\mathrm{PRh}}=144 \mathrm{~Hz}\right) \mathrm{ppm}$.

[RhCl(COD) $\left.\left(\mathbf{P M e}_{2} \mathbf{A r}^{\mathrm{Dipp}_{2}}\right)\right], \mathbf{1} \cdot \mathbf{L 5}$. The synthesis of this complex is analogous to that of $\left[\mathrm{RhCl}(\mathrm{COD})\left(\mathrm{PMe}_{2} \mathrm{Ar}^{\mathrm{Xyl}}\right)\right]$ using $\mathbf{L 5}$ instead of $\mathbf{L 1}$ (Yield: $90 \%$ ). Anal. Calc. for $\mathrm{C}_{40} \mathrm{H}_{55} \mathrm{ClPRh}$ : C, 68.1; H, 7.9. Found: C, 68.4; H, 8.2. ${ }^{1} \mathrm{H}$ NMR $\left(500 \mathrm{MHz}, 25^{\circ} \mathrm{C}, \mathrm{CD}_{2} \mathrm{Cl}_{2}\right): \delta 7.43\left(\mathrm{t}, 2 \mathrm{H},{ }^{3} J_{\mathrm{HH}}\right.$ $=7.9 \mathrm{~Hz}, p$-Dipp), $7.39\left(\mathrm{td}, 1 \mathrm{H},{ }^{3} J_{\mathrm{HH}}=7.6 \mathrm{~Hz},{ }^{5} J_{\mathrm{HP}}=1.7 \mathrm{~Hz}, p-\mathrm{C}_{6} \mathrm{H}_{3}\right), 7.32\left(\mathrm{~d}, 4 \mathrm{H},{ }^{3} J_{\mathrm{HH}}=7.9\right.$ $\mathrm{Hz}, p$-Dipp), 7.14 (dd, $\left.2 \mathrm{H},{ }^{3} J_{\mathrm{HH}}=7.6 \mathrm{~Hz},{ }^{4} J_{\mathrm{HP}}=2.6 \mathrm{~Hz}, m-\mathrm{C}_{6} \mathrm{H}_{3}\right), 4.90$ (br s, $2 \mathrm{H}, \mathrm{CH}-\mathrm{COD}$ ), 2.65 (br s, 2 H, CH-COD), 2.86 (br s, 4 H, CH-Dipp), 2.47, 2.18, 1.76, 1.64 (m, 8 H, $\mathrm{CH}_{2}$ ), 1.44, $0.99\left(\mathrm{~d}, 24 \mathrm{H},{ }^{3} J_{\mathrm{HH}}=6.9 \mathrm{H}, \mathrm{Me}-\mathrm{Dipp}\right), 1.09\left(\mathrm{~d}, 6 \mathrm{H},{ }^{2} J_{\mathrm{HP}}=7.9 \mathrm{~Hz}, \mathrm{PMe}_{2}\right) \mathrm{ppm} .{ }^{13} \mathrm{C}\left\{{ }^{1} \mathrm{H}\right\} \mathrm{NMR}$ $\left(125 \mathrm{MHz}, 25^{\circ} \mathrm{C}, \mathrm{CD}_{2} \mathrm{Cl}_{2}\right.$ ): $\delta 147.0$ (o-Dipp), $143.4\left(\mathrm{~d},{ }^{2} J_{\mathrm{CP}}=9 \mathrm{~Hz}, o-\mathrm{C}_{6} \mathrm{H}_{3}\right), 139.4\left(\mathrm{~d},{ }^{3} J_{\mathrm{CP}}=3\right.$ Hz, ipso-Dipp), $132.6\left(\mathrm{~d},{ }^{3} J_{\mathrm{CP}}=7 \mathrm{~Hz}, m-\mathrm{C}_{6} \mathrm{H}_{3}\right), 130.0\left(\mathrm{~d},{ }^{1} J_{\mathrm{CP}}=26 \mathrm{~Hz}\right.$, ipso- $\left.\mathrm{C}_{6} \mathrm{H}_{3}\right), 128.5$ (s, p- 
Dipp), $126.8\left(\mathrm{~d},{ }^{4} J_{\mathrm{CP}}=4 \mathrm{~Hz}, p-\mathrm{C}_{6} \mathrm{H}_{3}\right), 122.8\left(m\right.$-Dipp), $98.6\left(\mathrm{dd},{ }^{1} J_{\mathrm{CRh}}=14 \mathrm{~Hz},{ }^{2} J_{\mathrm{CP}}=8 \mathrm{~Hz}, \mathrm{CH}-\right.$ COD), $69.7\left(\mathrm{~d},{ }^{1} J_{\mathrm{CRh}}=14 \mathrm{~Hz}, \mathrm{CH}-\mathrm{COD}\right), 32.6\left(\mathrm{~d},{ }^{2} J_{\mathrm{CRh}}=4 \mathrm{~Hz}, \mathrm{CH}_{2}\right), 30.8$ (s, CH-Dipp), 28.6 $\left(\mathrm{d},{ }^{2} J_{\mathrm{CRh}}=2 \mathrm{~Hz}, \mathrm{CH}_{2}\right), 25.9,22.2$ (s, Me-Dipp), $14.4\left(\mathrm{~d},{ }^{1} J_{\mathrm{CP}}=25 \mathrm{~Hz}, \mathrm{PMe}_{2}\right) \mathrm{ppm} .{ }^{31} \mathrm{P}\left\{{ }^{1} \mathrm{H}\right\}$ $\operatorname{NMR}\left(200 \mathrm{MHz}, 25^{\circ} \mathrm{C}, \mathrm{CD}_{2} \mathrm{Cl}_{2}\right): \delta-6.9\left(\mathrm{~d},{ }^{1} J_{\mathrm{PRh}}=144 \mathrm{~Hz}\right) \mathrm{ppm}$.

$\left[\mathbf{R h C l}(\mathbf{C O})_{2}\left(\mathbf{P M e}_{2} \mathbf{A r}^{\mathrm{Xyl}}\right)\right], \mathbf{1 a} \cdot \mathbf{L 1}$. A solution of complex 1 $\cdot \mathbf{L 1}(0.08 \mathrm{mmol})$ in $\mathrm{CH}_{2} \mathrm{Cl}_{2}(5 \mathrm{~mL})$, placed in a thick-wall ampoule, was stirred for $10 \mathrm{~min}$ at room temperature under 1.5 bar of $\mathrm{CO}$. The solvent was evaporated under reduced pressure to obtain complex $\mathbf{1 a} \cdot \mathbf{L 1}$ as a yellow powder in $90 \%$ yield $(43 \mathrm{mg}$ ). Further purification can be performed by slow diffusion at -20 ${ }^{\circ} \mathrm{C}$ of pentane into a $\mathrm{CH}_{2} \mathrm{Cl}_{2}$ solution of the compound. Anal. Calc. for $\mathrm{C}_{26} \mathrm{H}_{27} \mathrm{ClO}_{2} \mathrm{PRh}: \mathrm{C}, 57.7$; H, 5.0. Found: C, 57.9; H, 5.1. IR (Nujol): 2078, $1994 \mathrm{~cm}^{-1} .{ }^{1} \mathrm{H}$ NMR $\left(400 \mathrm{MHz}, 25{ }^{\circ} \mathrm{C}\right.$, $\left.\mathrm{CD}_{2} \mathrm{Cl}_{2}\right): \delta 7.63\left(\mathrm{td}, 1 \mathrm{H},{ }^{3} J_{\mathrm{HH}}=7.6,{ }^{5} J_{\mathrm{HP}}=1.8 \mathrm{~Hz}, p-\mathrm{C}_{6} \mathrm{H}_{3}\right), 7.30\left(\mathrm{t}, 2 \mathrm{H},{ }^{3} J_{\mathrm{HH}}=7.5 \mathrm{~Hz}, p-\mathrm{Xyl}\right)$, $7.21\left(\mathrm{~d}, 4 \mathrm{H},{ }^{3} J_{\mathrm{HH}}=7.6 \mathrm{~Hz}, m-\mathrm{Xyl}\right), 7.12\left(\mathrm{dd}, 2 \mathrm{H},{ }^{3} J_{\mathrm{HH}}=7.6,{ }^{4} J_{\mathrm{HP}}=3.1 \mathrm{~Hz}, m-\mathrm{C}_{6} \mathrm{H}_{3}\right), 2.18(\mathrm{~s}$, $12 \mathrm{H}, \mathrm{Me}-\mathrm{Xyl}), 1.32\left(\mathrm{dd}, 6 \mathrm{H},{ }^{2} J_{\mathrm{HP}}=9.2,{ }^{3} J_{\mathrm{HRh}}=1.3 \mathrm{~Hz}, \mathrm{PMe}_{2}\right) \mathrm{ppm} .{ }^{13} \mathrm{C}\left\{{ }^{1} \mathrm{H}\right\} \mathrm{NMR}(100 \mathrm{MHz}$, $25^{\circ} \mathrm{C}, \mathrm{CD}_{2} \mathrm{Cl}_{2}$ ): $\delta 182.5\left(\mathrm{dd},{ }^{2} J_{\mathrm{CP}}=126,{ }^{1} J_{\mathrm{CRh}}=59 \mathrm{~Hz}, \mathrm{CO}\right.$ trans to $\left.\mathrm{P}\right), 182.2\left(\mathrm{dd},{ }^{1} J_{\mathrm{CRh}}=74\right.$, ${ }^{2} J_{\mathrm{CP}}=17 \mathrm{~Hz}, \mathrm{CO}$ cis to P), $146.6\left(\mathrm{~d},{ }^{2} J_{\mathrm{CP}}=10 \mathrm{~Hz}, o-\mathrm{C}_{6} \mathrm{H}_{3}\right), 141.3\left(\mathrm{~d},{ }^{3} J_{\mathrm{CP}}=5 \mathrm{~Hz}, \mathrm{C}_{\mathrm{ipso}}-\mathrm{Xyl}\right)$, 136.4 (s, o-Xyl), $131.3\left(\mathrm{~d},{ }^{4} J_{\mathrm{CP}}=2 \mathrm{~Hz}, p-\mathrm{C}_{6} \mathrm{H}_{3}\right), 130.9\left(\mathrm{~d},{ }^{3} J_{\mathrm{CP}}=7 \mathrm{~Hz}, m-\mathrm{C}_{6} \mathrm{H}_{3}\right), 128.1$ (s, $p$ $\mathrm{Xyl}), 128.0$ (s, $m$-Xyl), 127.7 (d, $\left.{ }^{1} J_{\mathrm{CP}}=41 \mathrm{~Hz}, \mathrm{C}_{\mathrm{ipso}}-\mathrm{C}_{6} \mathrm{H}_{3}\right), 21.8$ (s, Me-Xyl), 16.3 (d, ${ }^{1} J_{\mathrm{CP}}=32$ $\left.\mathrm{Hz}, \mathrm{PMe}_{2}\right)$ ppm. ${ }^{31} \mathrm{P}\left\{{ }^{1} \mathrm{H}\right\}$ NMR $\left(160 \mathrm{MHz}, 25^{\circ} \mathrm{C}, \mathrm{CD}_{2} \mathrm{Cl}_{2}\right): \delta-7.1\left(\mathrm{~d},{ }^{1} J_{\mathrm{PRh}}=121 \mathrm{~Hz}\right) \mathrm{ppm}$.

$\left[\mathbf{R h C l}(\mathbf{C O})_{2}\left(\mathbf{P M e}_{2} \mathrm{Ar}^{\mathrm{Dipp}_{2}}\right)\right], \mathbf{1 a} \cdot \mathbf{L 5}$. The synthesis of this complex is analogous to that of $\left[\mathrm{RhCl}(\mathrm{CO})_{2}\left(\mathrm{PMe}_{2} \mathrm{Ar}^{\mathrm{Xyl}}\right)\right]$ using $\mathbf{1 a} \cdot \mathbf{L 5}$ instead of $\mathbf{1 a} \cdot \mathbf{L 1}$ (Yield: 90\%). Anal. Calc. for $\mathrm{C}_{34} \mathrm{H}_{43} \mathrm{ClO}_{2} \mathrm{PRh}$ : C, 62.5; H, 6.6. Found: C, 62.4; H, 6.6. IR (Nujol): 2070, $1990 \mathrm{~cm}^{-1}$. ${ }^{1} \mathrm{H}$ NMR $\left(400 \mathrm{MHz}, 25^{\circ} \mathrm{C}, \mathrm{CD}_{2} \mathrm{Cl}_{2}\right): \delta 7.51\left(\mathrm{td}, 1 \mathrm{H},{ }^{3} J_{\mathrm{HH}}=7.6 \mathrm{~Hz},{ }^{5} J_{\mathrm{HP}}=1.8 \mathrm{~Hz}, p\right.$-Dipp), $7.44(\mathrm{t}, 2 \mathrm{H}$, ${ }^{3} J_{\mathrm{HH}}=7.7 \mathrm{~Hz}, p$-Dipp), $7.31\left(\mathrm{~d}, 4 \mathrm{H},{ }^{3} J_{\mathrm{HH}}=7.7 \mathrm{~Hz}, m\right.$-Dipp), $7.27\left(\mathrm{dd}, 2 \mathrm{H},{ }^{3} J_{\mathrm{HH}}=7.8 \mathrm{~Hz},{ }^{4} J_{\mathrm{HP}}\right.$ $\left.=3.0 \mathrm{~Hz}, m-\mathrm{C}_{6} \mathrm{H}_{3}\right), 2.75$ (sept, $\left.4 \mathrm{H},{ }^{3} J_{\mathrm{HH}}=6.8 \mathrm{~Hz}, \mathrm{CH}-\mathrm{Dipp}\right), 1.42\left(\mathrm{~d}, 12 \mathrm{H},{ }^{3} J_{\mathrm{HH}}=6.7 \mathrm{~Hz}, \mathrm{Me}-\right.$ Dipp), $1.03\left(\mathrm{~d}, 12 \mathrm{H},{ }^{3} J_{\mathrm{HH}}=6.7 \mathrm{~Hz}\right.$, Me-Dipp), $1.25\left(\mathrm{dd}, 6 \mathrm{H},{ }^{2} J_{\mathrm{HP}}=9.5 \mathrm{~Hz},{ }^{3} J_{\mathrm{HRh}}=1.3 \mathrm{~Hz}\right.$, $\left.\mathrm{PMe}_{2}\right)$ ppm. ${ }^{13} \mathrm{C}\left\{{ }^{1} \mathrm{H}\right\} \mathrm{NMR}\left(100 \mathrm{MHz}, 25{ }^{\circ} \mathrm{C}, \mathrm{CD}_{2} \mathrm{Cl}_{2}\right): \delta 182.7\left(\mathrm{dd},{ }^{2} J_{\mathrm{CP}}=127 \mathrm{~Hz},{ }^{1} J_{\mathrm{CRh}}=59\right.$ $\mathrm{Hz}, \mathrm{CO}$ trans to P), 182.3 (dd, ${ }^{1} J_{\mathrm{CRh}}=57 \mathrm{~Hz},{ }^{2} J_{\mathrm{CP}}=17 \mathrm{~Hz}, \mathrm{CO}$ cis to P), 147.1 (s, o-Dipp), $144.3\left(\mathrm{~d},{ }^{2} J_{\mathrm{CP}}=10 \mathrm{~Hz}, o-\mathrm{C}_{6} \mathrm{H}_{3}\right), 138.9\left(\mathrm{~d},{ }^{3} J_{\mathrm{CP}}=4 \mathrm{~Hz}, \mathrm{C}_{\mathrm{ipso}}-\mathrm{Dipp}\right), 133.1\left(\mathrm{~d},{ }^{3} J_{\mathrm{CP}}=8 \mathrm{~Hz}, m-\right.$ $\left.\mathrm{C}_{6} \mathrm{H}_{3}\right), 129.7$ (d, $\left.{ }^{1} J_{\mathrm{CP}}=51 \mathrm{~Hz}, \mathrm{C}_{\mathrm{ipso}}-\mathrm{C}_{6} \mathrm{H}_{3}\right), 129.0$ (s, $p$-Dipp), 128.1 (d, ${ }^{3} J_{\mathrm{CP}}=2 \mathrm{~Hz}, p$-Dipp), 123.2 (s, $m$-Dipp), 31.0 (s, CH-Dipp), 25.8 (s, Me-Dipp), 22.9 (s, Me-Dipp), 16.6 (d, ${ }^{1} J_{\mathrm{CP}}=33$ $\left.\mathrm{Hz}, \mathrm{PMe}_{2}\right)$ ppm. ${ }^{31} \mathrm{P}\left\{{ }^{1} \mathrm{H}\right\} \mathrm{NMR}\left(160 \mathrm{MHz}, 25^{\circ} \mathrm{C}, \mathrm{CD}_{2} \mathrm{Cl}_{2}\right): \delta-4.1\left(\mathrm{~d},{ }^{1} J_{\mathrm{PRh}}=121 \mathrm{~Hz}\right) \mathrm{ppm}$.

[IrCl(COD)(PMe $\left.\left.\mathbf{A r}^{\mathbf{X y l}_{2}}\right)\right], \mathbf{2} \cdot \mathbf{L 1}$. A solid mixture of $[\mathrm{IrCl}(\operatorname{cod})]_{2}(75 \mathrm{mg}, 0.112 \mathrm{mmol})$ and $\mathrm{PMe}_{2} \mathrm{Ar}^{\mathrm{Xyl}_{2}}$ (78 mg, $0.225 \mathrm{mmol}$ ) was dissolved in $\mathrm{CH}_{2} \mathrm{Cl}_{2}(7 \mathrm{~mL})$ and stirred for $1 \mathrm{~h}$. The solvent was removed under reduced pressure and the solid residue washed with $2 \mathrm{~mL}$ of cold pentane, providing $\mathbf{2} \cdot \mathbf{L 1}$ a bright yellow solid (Yield: $141 \mathrm{mg}, 92 \%$ ). Anal. Calcd. for $\mathrm{C}_{32} \mathrm{H}_{39}$ ClIrP: C, 56.33; H, 5.76. Found: C, 56.6; H, 5.8. ${ }^{1} \mathrm{H}$ NMR $\left(400 \mathrm{MHz}, \mathrm{CD}_{2} \mathrm{Cl}_{2}, 25{ }^{\circ} \mathrm{C}\right): \delta$ $7.48\left(\mathrm{td}, 1 \mathrm{H},{ }^{3} J_{\mathrm{HH}}=7.6 \mathrm{~Hz},{ }^{5} J_{\mathrm{HP}}=1.7 \mathrm{~Hz}, p-\mathrm{C}_{6} \mathrm{H}_{3}\right), 7.22(\mathrm{~m}, 2 \mathrm{H}, p-\mathrm{Xyl}), 7.13\left(\mathrm{~d}, 4 \mathrm{H},{ }^{3} J_{\mathrm{HH}}=\right.$ $7.8 \mathrm{~Hz}, m-\mathrm{Xyl}), 6.99\left(\mathrm{dd}, 2 \mathrm{H},{ }^{3} \mathrm{~J}_{\mathrm{HH}}=7.6 \mathrm{~Hz},{ }^{4} J_{\mathrm{HP}}=2.8 \mathrm{~Hz}, m-\mathrm{C}_{6} \mathrm{H}_{3}\right), 4.57$ (m, $\left.2 \mathrm{H}, \mathrm{CH}-\mathrm{COD}\right)$, 2.27 (m, $2 \mathrm{H}, \mathrm{CH}-\mathrm{COD}), 2.22$ (s, $12 \mathrm{H}, \mathrm{Me}-\mathrm{Xyl}$ ), 2.12 (m, $2 \mathrm{H}, \mathrm{CH}_{2}-\mathrm{COD}$ ), 1.96 (m, $2 \mathrm{H}, \mathrm{CH}_{2^{-}}$ $\mathrm{COD}$ ), 1.54 (m, $\left.2 \mathrm{H}, \mathrm{CH}_{2}-\mathrm{COD}\right), 1.37\left(\mathrm{~m}, 2 \mathrm{H}, \mathrm{CH}_{2}-\mathrm{COD}\right), 1.07$ (d, $6 \mathrm{H},{ }^{2} J_{\mathrm{HP}}=8.4 \mathrm{~Hz}, \mathrm{PMe}_{2}$ ) ppm. ${ }^{13} \mathrm{C}\left\{{ }^{1} \mathrm{H}\right\}$ NMR $\left(100 \mathrm{MHz}, \mathrm{CD}_{2} \mathrm{Cl}_{2}, 25^{\circ} \mathrm{C}\right): \delta 146.6\left(\mathrm{~d},{ }^{2} J_{\mathrm{CP}}=9 \mathrm{~Hz}, o-\mathrm{C}_{6} \mathrm{H}_{3}\right), 142.2\left(\mathrm{~d},{ }^{3} J_{\mathrm{CP}}\right.$ $\left.=4 \mathrm{~Hz}, \mathrm{C}_{\mathrm{ipso}}-\mathrm{Xyl}\right), 137.5(\mathrm{~s}, o-\mathrm{Xyl}), 131.1\left(\mathrm{~d},{ }^{3} J_{\mathrm{CP}}=8 \mathrm{~Hz}, m-\mathrm{C}_{6} \mathrm{H}_{3}\right), 130.5\left(\mathrm{~d},{ }^{4} J_{\mathrm{CP}}=2 \mathrm{~Hz}, p-\right.$ $\left.\mathrm{C}_{6} \mathrm{H}_{3}\right), 130.2\left(\mathrm{~d},{ }^{1} J_{\mathrm{CP}}=42 \mathrm{~Hz}, \mathrm{C}_{\mathrm{ipso}}-\mathrm{C}_{6} \mathrm{H}_{3}\right), 128.3$ (s, $p$-Xyl), 127.9 (s, $\left.m-\mathrm{Xyl}\right), 88.8\left(\mathrm{~d},{ }^{2} J_{\mathrm{CP}}=16\right.$ $\mathrm{Hz}, \mathrm{CH}-\mathrm{COD}$ ), 52.1 (s, CH-COD), 34.1 (d, $\left.{ }^{3} \mathrm{~J}_{\mathrm{CP}}=3 \mathrm{~Hz}, \mathrm{CH}_{2}-\mathrm{COD}\right), 29.2$ (d, ${ }^{3} \mathrm{~J}_{\mathrm{CP}}=2 \mathrm{~Hz}, \mathrm{CH}_{2^{-}}$ 
COD), 22.6 (s, Me-Xyl), $12.7\left(\mathrm{~d},{ }^{1} J_{\mathrm{CP}}=31 \mathrm{~Hz}, \mathrm{PMe}_{2}\right)$ ppm. ${ }^{31} \mathrm{P}\left\{{ }^{1} \mathrm{H}\right\} \mathrm{NMR}\left(160 \mathrm{MHz}, \mathrm{CD}_{2} \mathrm{Cl}_{2}\right.$, $\left.25^{\circ} \mathrm{C}\right): \delta-9.3(\mathrm{~s}) \mathrm{ppm}$.

$\left[\operatorname{IrCl}(\mathbf{C O D})\left(\mathbf{P M e}_{2} \mathbf{A r}^{\mathrm{Dipp}_{2}}\right)\right], \mathbf{2} \cdot \mathbf{L 5}$. The synthesis of this complex is analogous to that of [ $\left.\mathrm{IrCl}(\mathrm{COD})\left(\mathrm{PMe}_{2} \mathrm{Ar}^{\mathrm{Xyl}}\right)\right]$ using $\mathbf{L 5}$ instead of $\mathbf{~ L 1}$ (Yield: 94\%). Anal. Calcd. for $\mathrm{C}_{40} \mathrm{H}_{55} \mathrm{ClIrP}: \mathrm{C}$, 60.47; H, 6.98. Found: C, 60.2; H, 7.0. ${ }^{1} \mathrm{H}$ NMR (400 MHz, $\left.\mathrm{CD}_{2} \mathrm{Cl}_{2}, 25{ }^{\circ} \mathrm{C}\right): \delta 7.41\left(\mathrm{t}, 2 \mathrm{H},{ }^{3} J_{\mathrm{HH}}\right.$ $=7.6 \mathrm{~Hz}, p$-Dipp), $7.39\left(\mathrm{td}, 1 \mathrm{H},{ }^{3} J_{\mathrm{HH}}=7.4 \mathrm{~Hz},{ }^{5} J_{\mathrm{HP}}=1.6 \mathrm{~Hz}, p-\mathrm{C}_{6} \mathrm{H}_{3}\right), 7.28\left(\mathrm{~d}, 4 \mathrm{H},{ }^{3} J_{\mathrm{HH}}=7.8\right.$ $\mathrm{Hz}, m$-Dipp), $7.16\left(\mathrm{dd}, 1 \mathrm{H},{ }^{3} J_{\mathrm{HH}}=7.6 \mathrm{~Hz},{ }^{4} J_{\mathrm{HP}}=2.7 \mathrm{~Hz}, m-\mathrm{C}_{6} \mathrm{H}_{3}\right), 4.50$ (br, $\left.2 \mathrm{H}, \mathrm{CH}-\mathrm{COD}\right)$, 2.87 (br, 4 H, CH-Dipp), 2.33 (br, $2 \mathrm{H}, \mathrm{CH}-\mathrm{COD}$ ), 2.00 (br, $4 \mathrm{H}, \mathrm{CH}_{2}-\mathrm{COD}$ ), 1.52 (m, $2 \mathrm{H}$, $\mathrm{CH}_{2}$-COD), $1.40\left(\mathrm{~d}, 12 \mathrm{H},{ }^{3} J_{\mathrm{HH}}=6.7 \mathrm{~Hz}, \mathrm{Me}-\mathrm{Dipp}\right), 1.29\left(\mathrm{~m}, 2 \mathrm{H}, \mathrm{CH}_{2}-\mathrm{COD}\right), 1.12\left(\mathrm{~d}, 6 \mathrm{H},{ }^{2} J_{\mathrm{HP}}\right.$ $\left.=8.6 \mathrm{~Hz}, \mathrm{PMe}_{2}\right), 1.01\left(\mathrm{~d}, 12 \mathrm{H},{ }^{3} J_{\mathrm{HH}}=6.7 \mathrm{~Hz}, \mathrm{Me}-\mathrm{Dipp}\right) \mathrm{ppm} .{ }^{13} \mathrm{C}\left\{{ }^{1} \mathrm{H}\right\} \mathrm{NMR}(100 \mathrm{MHz}$, $\left.\mathrm{CD}_{2} \mathrm{Cl}_{2}, 25^{\circ} \mathrm{C}\right): \delta 147.9$ (s, o-Dipp), $144.8\left(\mathrm{~d},{ }^{2} J_{\mathrm{CP}}=9 \mathrm{~Hz}, o-\mathrm{C}_{6} \mathrm{H}_{3}\right), 140.1\left(\mathrm{~d},{ }^{3} J_{\mathrm{CP}}=4 \mathrm{~Hz}, \mathrm{C}_{\mathrm{ipso}}{ }^{-}\right.$ Dipp), $133.1\left(\mathrm{~d},{ }^{3} J_{\mathrm{CP}}=7 \mathrm{~Hz}, m-\mathrm{C}_{6} \mathrm{H}_{3}\right), 131.3\left(\mathrm{~d},{ }^{1} J_{\mathrm{CP}}=39 \mathrm{~Hz}\right.$, ipso- $\left.\mathrm{C}_{6} \mathrm{H}_{3}\right), 129.2$ (s, $p$-Dipp), $127.5\left(\mathrm{~d},{ }^{4} J_{\mathrm{CP}}=2 \mathrm{~Hz}, p-\mathrm{C}_{6} \mathrm{H}_{3}\right), 123.2$ (s, $m$-Dipp), $86.6\left(\mathrm{~d},{ }^{2} J_{\mathrm{CP}}=16 \mathrm{~Hz}, \mathrm{CH}_{\mathrm{cod}}\right), 53.0(\mathrm{~s}, \mathrm{CH}-$ COD), 33.6 (d, ${ }^{3} J_{\mathrm{CP}}=4 \mathrm{~Hz}, \mathrm{CH}_{2}-\mathrm{COD}$ ), 31.3 (s, CH-Dipp), 29.8 (d, ${ }^{3} J_{\mathrm{CP}}=2 \mathrm{~Hz}, \mathrm{CH}_{2}-\mathrm{COD}$ ), 26.3 (s, Me-Dipp), 23.4 (s, Me-Dipp), 14.4 (d, $\left.{ }^{1} J_{\mathrm{CP}}=31 \mathrm{~Hz}, \mathrm{PMe}_{2}\right) \mathrm{ppm} .{ }^{31} \mathrm{P}\left\{{ }^{1} \mathrm{H}\right\} \mathrm{NMR}(160$ $\mathrm{MHz}, \mathrm{CD}_{2} \mathrm{Cl}_{2}, 25^{\circ} \mathrm{C}$ ): $\delta-9.0$ (s) ppm.

$\left[\operatorname{IrCl}(\mathbf{C O})_{2}\left(\mathbf{P M e}_{2} \mathbf{A r}^{\mathrm{Xyl}_{2}}\right)\right], \mathbf{2 a} \cdot \mathbf{L 1}$. A thick-wall ampoule was charged with complex $\mathbf{2} \cdot \mathbf{L 1}$ (52 $\mathrm{mg}, 0.076 \mathrm{mmol}), \mathrm{CH}_{2} \mathrm{Cl}_{2}(4 \mathrm{~mL})$, and $\mathrm{CO}$ (1.5 bar). The solution turned pale yellow and was stirred for $30 \mathrm{~min}$. The solvent was removed under vacuum, yielding $\mathbf{2} \mathbf{a} \cdot \mathbf{L} \mathbf{1}$ as a pale yellow powder (45 mg, 94\%), which was further purified by crystallization from a saturated hexane solution at $-32{ }^{\circ} \mathrm{C}$. Anal. Calcd. for $\mathrm{C}_{26} \mathrm{H}_{27} \mathrm{ClIrO}_{2} \mathrm{P}: \mathrm{C}, 49.56$; H, 4.32. Found: C, 49.6; H, 4.2. IR (Nujol): v(CO) 2067, $1985 \mathrm{~cm}^{-1} .{ }^{1} \mathrm{H}$ NMR (400 MHz, $\left.\mathrm{CD}_{2} \mathrm{Cl}_{2}, 25{ }^{\circ} \mathrm{C}\right): \delta 7.59\left(\mathrm{t}, 1 \mathrm{H},{ }^{3} \mathrm{~J}_{\mathrm{HH}}=\right.$ $\left.7.6 \mathrm{~Hz}, p-\mathrm{C}_{6} \mathrm{H}_{3}\right), 7.26(\mathrm{~m}, 2 \mathrm{H}, p-\mathrm{Xyl}), 7.17\left(\mathrm{~d}, 4 \mathrm{H},{ }^{3} J_{\mathrm{HH}}=7.5 \mathrm{~Hz}, m-\mathrm{Xyl}\right) 7.10\left(\mathrm{dd}, 2 \mathrm{H},{ }^{3} J_{\mathrm{HH}}=\right.$ $\left.7.6 \mathrm{~Hz},{ }^{4} J_{\mathrm{HP}}=3.1 \mathrm{~Hz}, m-\mathrm{C}_{6} \mathrm{H}_{3}\right), 2.13(\mathrm{~s}, 12 \mathrm{H}, \mathrm{Me}-\mathrm{Xyl}), 1.36\left(\mathrm{~d}, 6 \mathrm{H},{ }^{2} J_{\mathrm{HP}}=9.7 \mathrm{~Hz}, \mathrm{PMe}_{2}\right) \mathrm{ppm}$. ${ }^{13} \mathrm{C}\left\{{ }^{1} \mathrm{H}\right\}$ NMR $\left(100 \mathrm{MHz}, \mathrm{CD}_{2} \mathrm{Cl}_{2}, 25{ }^{\circ} \mathrm{C}\right): \delta 177.7\left(\mathrm{~d},{ }^{2} J_{\mathrm{CP}}=126 \mathrm{~Hz}, \mathrm{CO}\right.$ trans to $\left.\mathrm{P}\right), 168.3$ (d, ${ }^{2} J_{\mathrm{CP}}=13 \mathrm{~Hz}, \mathrm{CO}$ cis to P), $147.3\left(\mathrm{~d},{ }^{2} J_{\mathrm{CP}}=10 \mathrm{~Hz}, o-\mathrm{C}_{6} \mathrm{H}_{3}\right), 141.6\left(\mathrm{~d},{ }^{3} J_{\mathrm{CP}}=4 \mathrm{~Hz}, \mathrm{C}_{\mathrm{ipso}}-\mathrm{Xyl}\right)$, 136.9 (s, o-Xyl), $132.0\left(\mathrm{~d},{ }^{4} J_{\mathrm{CP}}=2 \mathrm{~Hz}, p-\mathrm{C}_{6} \mathrm{H}_{3}\right), 131.4\left(\mathrm{~d},{ }^{3} J_{\mathrm{CP}}=8 \mathrm{~Hz}, m-\mathrm{C}_{6} \mathrm{H}_{3}\right), 128.6$ (s, $p-$ $\mathrm{Xyl}), 128.5$ (s, $m$-Xyl), 127.3 (d, $\left.{ }^{1} J_{\mathrm{CP}}=48 \mathrm{~Hz}, \mathrm{C}_{\mathrm{ipso}}-\mathrm{C}_{6} \mathrm{H}_{3}\right), 22.3$ (s, Me-Xyl), 16.3 (d, ${ }^{1} J_{\mathrm{CP}}=38$ $\left.\mathrm{Hz}, \mathrm{PMe}_{2}\right)$ ppm. ${ }^{31} \mathrm{P}\left\{{ }^{1} \mathrm{H}\right\}$ NMR $\left(160 \mathrm{MHz}, \mathrm{CD}_{2} \mathrm{Cl}_{2}, 25{ }^{\circ} \mathrm{C}\right): \delta-10.9$ (s) ppm.

$\left[\operatorname{IrCl}(\mathbf{C O})_{2}\left(\mathbf{P M e}_{2} \mathbf{A r}^{\text {Dipp }_{2}}\right)\right], \mathbf{2 a} \cdot \mathbf{L 5}$. [ $\left.\operatorname{IrCl}(\operatorname{cod}) \mathrm{PMe}_{2} \mathrm{Ar}^{\mathrm{Dipp}_{2}}\right]_{2}(96 \mathrm{mg}, 0.120 \mathrm{mmol})$ was dissolved in dry $\mathrm{CH}_{2} \mathrm{Cl}_{2}(4 \mathrm{~mL})$ in a thick-wall ampoule and stirred for $30 \mathrm{~min}$ at room temperature under 1.5 bar of $\mathrm{CO}$. The solvent was evaporated under reduced pressure to obtain a pale yellow/greenish powder (Yield: $71 \mathrm{mg}, 80 \%$ ). This compound was isolated as a crystalline solid by slow diffusion of pentane into a dichloromethane solution of the complex at $-32{ }^{\circ} \mathrm{C}$. Anal. Calcd. for $\mathrm{C}_{34} \mathrm{H}_{43} \mathrm{ClIrO}_{2} \mathrm{P}: \mathrm{C}, 55.01 ; \mathrm{H}, 5.84$. Found: C, 55.2; H, 6.2. IR (Nujol): v(CO) 2059, $1978 \mathrm{~cm}^{-1} .{ }^{1} \mathrm{H}$ NMR $\left(500 \mathrm{MHz}, \mathrm{CD}_{2} \mathrm{Cl}_{2}, 25^{\circ} \mathrm{C}\right) \delta: 7.48\left(\mathrm{td}, 1 \mathrm{H},{ }^{3} J_{\mathrm{HH}}=7.6 \mathrm{~Hz},{ }^{5} J_{\mathrm{HP}}=1.7\right.$ $\left.\mathrm{Hz}, p-\mathrm{C}_{6} \mathrm{H}_{3}\right), 7.41\left(\mathrm{t}, 2 \mathrm{H},{ }^{3} J_{\mathrm{HH}}=7.8 \mathrm{~Hz}, p\right.$-Dipp), $7.28\left(\mathrm{~d}, 4 \mathrm{H},{ }^{3} J_{\mathrm{HH}}=7.8 \mathrm{~Hz}, m\right.$-Dipp), 7.25 $\left(\mathrm{dd}, 2 \mathrm{H},{ }^{3} J_{\mathrm{HH}}=7.7 \mathrm{~Hz},{ }^{4} J_{\mathrm{HP}}=3.3 \mathrm{~Hz}, m-\mathrm{C}_{6} \mathrm{H}_{3}\right.$ ), 2.71 (sept, $\left.4 \mathrm{H},{ }^{3} J_{\mathrm{HH}}=6.7 \mathrm{~Hz}, \mathrm{CH}-\mathrm{Dipp}\right), 1.40$ $\left(\mathrm{d}, 12 \mathrm{H},{ }^{3} J_{\mathrm{HH}}=6.7 \mathrm{~Hz}, \mathrm{Me}-\mathrm{Dipp}\right), 1.28\left(\mathrm{~d}, 6 \mathrm{H},{ }^{2} J_{\mathrm{HP}}=9.9 \mathrm{~Hz}, \mathrm{PMe}_{2}\right), 1.00\left(\mathrm{~d}, 12 \mathrm{H},{ }^{3} J_{\mathrm{HH}}=6.7\right.$ $\mathrm{Hz}$, Me-Dipp) ppm. ${ }^{13} \mathrm{C}\left\{{ }^{1} \mathrm{H}\right\} \mathrm{NMR}\left(125 \mathrm{MHz}, \mathrm{CD}_{2} \mathrm{Cl}_{2}, 25^{\circ} \mathrm{C}\right) \delta: 178.1\left(\mathrm{~d},{ }^{2} J_{\mathrm{CP}}=126 \mathrm{~Hz}, \mathrm{CO}\right.$ trans to $\mathrm{P}$ ), 168.6 (d, ${ }^{2} J_{\mathrm{CP}}=13 \mathrm{~Hz}, \mathrm{CO}$ cis to P), 147.6 (s, o-Dipp), 145.1 (d, ${ }^{2} J_{\mathrm{CP}}=10 \mathrm{~Hz}, o$ $\left.\mathrm{C}_{6} \mathrm{H}_{3}\right), 139.3\left(\mathrm{~d},{ }^{3} J_{\mathrm{CP}}=3 \mathrm{~Hz}, \mathrm{C}_{\text {ipso }}\right.$-Dipp), 133.5 (d, $\left.{ }^{3} J_{\mathrm{CP}}=8 \mathrm{~Hz}, m-\mathrm{C}_{6} \mathrm{H}_{3}\right), 129.5$ (s, $p$-Dipp), $128.9\left(\mathrm{~d},{ }^{1} J_{\mathrm{CP}}=48 \mathrm{~Hz}, \mathrm{C}_{\mathrm{ipso}}-\mathrm{C}_{6} \mathrm{H}_{3}\right), 128.8$ (s, $\left.p-\mathrm{C}_{6} \mathrm{H}_{3}\right), 123.7$ (s, $m$-Dipp), 31.5 (s, CH-Dipp), 26.1 (s, Me-Dipp), 23.4 (s, Me-Dipp), 16.5 (d, $\left.{ }^{1} J_{\mathrm{CP}}=38 \mathrm{~Hz}, \mathrm{PMe}_{2}\right) \mathrm{ppm} .{ }^{31} \mathrm{P}\left\{{ }^{1} \mathrm{H}\right\} \mathrm{NMR}(200$ $\mathrm{MHz}, \mathrm{CD}_{2} \mathrm{Cl}_{2}, 25^{\circ} \mathrm{C}$ ) $\delta:-7.8$ (s) ppm. 
trans-[PtCl $\left.\left.\mathbf{P M e}_{2} \mathbf{P M r}^{\mathrm{Xyl}_{2}}\right)_{2}\right]$, 3 $\mathbf{L 1} . \mathrm{PtCl}_{2}(\mathrm{COD})(40 \mathrm{mg}, 0.11 \mathrm{mmol})$ and $\mathrm{PMe}_{2} \mathrm{Ar}^{\mathrm{Xyl}_{2}}(75 \mathrm{mg}$, $0.22 \mathrm{mmol}$ ) were dissolved and stirred overnight in toluene at $110{ }^{\circ} \mathrm{C}$. The solvent was removed by evaporation under reduced pressure to obtain the compound as a colorless solid (Yield: 98 mg, 95\%). Anal. Calc. for $\mathrm{C}_{48} \mathrm{H}_{54} \mathrm{Cl}_{2} \mathrm{P}_{2} \mathrm{Pt}$ : C, 60.12; H, 5.73. Found: C, 60.1; H, 5.7. ${ }^{1} \mathrm{H}$ NMR $\left(300 \mathrm{MHz}, 25^{\circ} \mathrm{C}, \mathrm{CDCl}_{3}\right): \delta 7.39\left(\mathrm{t}, 2 \mathrm{H},{ }^{3} J_{\mathrm{HH}}=7,6 \mathrm{~Hz}, p-\mathrm{C}_{6} \mathrm{H}_{3}\right), 7.1(\mathrm{~m}, 4 \mathrm{H}, p-\mathrm{Xyl}), 6.99(\mathrm{~d}, 8$ $\left.\mathrm{H},{ }^{3} J_{\mathrm{HH}}=7.5 \mathrm{~Hz}, m-\mathrm{Xyl}\right), 6.88\left(\mathrm{~d}, 4 \mathrm{H},{ }^{3} J_{\mathrm{HH}}=7,6 \mathrm{~Hz}, m-\mathrm{C}_{6} \mathrm{H}_{3}\right), 2.07(\mathrm{~s}, 24 \mathrm{H}, \mathrm{Me}-\mathrm{Xyl}), 1.14(\mathrm{t}$, $\left.12 \mathrm{H},{ }^{2} J_{\mathrm{PH}}=3.6 \mathrm{~Hz}, \mathrm{PMe}_{2}\right) \mathrm{ppm} .{ }^{13} \mathrm{C}\left\{{ }^{1} \mathrm{H}\right\} \mathrm{NMR}\left(75.4 \mathrm{MHz}, 25{ }^{\circ} \mathrm{C}, \mathrm{CDCl}_{3}\right): \delta 146.5\left(\mathrm{~s}, o-\mathrm{C}_{6} \mathrm{H}_{3}\right)$, 141.9 (s, $\left.\mathrm{C}_{\mathrm{ipso}}-\mathrm{Xyl}\right), 136.5$ (s, o-Xyl), 130.9 (s, $\left.m-\mathrm{C}_{6} \mathrm{H}_{3}\right), 130.4$ (s, $\left.p-\mathrm{C}_{6} \mathrm{H}_{3}\right), 128.5\left(\mathrm{~s}, \mathrm{C}_{\mathrm{ipso}}-\mathrm{C}_{6} \mathrm{H}_{3}\right)$, 127.7 (s, $m$-Xyl), 127.5 (s, $p$-Xyl), 21.1 (s, Me-Xyl), $13.9\left(\mathrm{t},{ }^{1} J_{\mathrm{PC}}=19 \mathrm{~Hz}, \mathrm{PMe}_{2}\right) \mathrm{ppm} .{ }^{31} \mathrm{P}\left\{{ }^{1} \mathrm{H}\right\}$ NMR $\left(121.4 \mathrm{MHz}, 25^{\circ} \mathrm{C}, \mathrm{CDCl}_{3}\right): \delta-17.3\left(\mathrm{~s},{ }^{1} J_{\mathrm{PPt}}=2555 \mathrm{~Hz}\right) \mathrm{ppm}$.

cis-[PtCl $\left.\mathbf{P}_{2}\left(\boldsymbol{\kappa}^{2}-\mathbf{P M e}_{2} \mathbf{A r}^{\mathrm{Tipp}_{2}}\right)\right], \mathbf{3} \cdot \mathbf{L 8}$. A solution of $\mathbf{L 8}(200 \mathrm{mg}, 0.37 \mathrm{mmol})$ in toluene $(5 \mathrm{ml})$ was added under nitrogen to a suspension of $\mathrm{PtCl}_{2}(90 \mathrm{mg}, 0.34 \mathrm{mmol})$ in toluene $(5 \mathrm{ml})$. The reaction mixture was heated at $80^{\circ} \mathrm{C}$ for 3 days. During this time the colour of the mixture changed from brown to red. All volatiles were removed under vacuum and the residue was washed with pentane $(3 \times 20 \mathrm{~mL})$, giving the product as an orange powder (Yield: $233 \mathrm{mg}$, 85\%). Anal. Calc. for $\mathrm{C}_{38} \mathrm{H}_{55} \mathrm{Cl}_{2} \mathrm{PPt} \cdot \mathrm{CH}_{2} \mathrm{Cl}_{2}$ : C, 52.4; H, 6.4. Found: C, 52.2; H, 6.7. ${ }^{1} \mathrm{H} \mathrm{NMR}$ $\left(400 \mathrm{MHz}, 25^{\circ} \mathrm{C}, \mathrm{CD}_{2} \mathrm{Cl}_{2}\right): \delta 7.44\left(\mathrm{t}, 1 \mathrm{H},{ }^{3} J_{\mathrm{HH}}=7.6 \mathrm{~Hz}, p-\mathrm{C}_{6} \mathrm{H}_{3}\right), 7.19\left(\mathrm{~d}, 1 \mathrm{H},{ }^{3} J_{\mathrm{HH}}=7.2 \mathrm{~Hz}\right.$, $m$ - $\mathrm{C}_{6} \mathrm{H}_{3}$ ), 7.14 (s, $2 \mathrm{H}, m$-Tipp), 7.06 (s, $2 \mathrm{H}, m$-Tipp'), 6.68 (d, $1 \mathrm{H},{ }^{3} J_{\mathrm{HH}}=7.7 \mathrm{~Hz}, m_{-}-\mathrm{C}_{6} \mathrm{H}_{3}$ ), 3.09 (sept, $1 \mathrm{H},{ }^{3} J_{\mathrm{HH}}=6.6 \mathrm{~Hz}, p$-CH-Tipp), 2.98 (sept, $1 \mathrm{H},{ }^{3} J_{\mathrm{HH}}=6.9 \mathrm{~Hz}, p$-CH-Tipp), 2.34 (sept, $2 \mathrm{H},{ }^{3} J_{\mathrm{HH}}=6.5 \mathrm{~Hz}, o$-CH-Tipp), 2.32 (sept, $2 \mathrm{H},{ }^{3} J_{\mathrm{HH}}=6.5 \mathrm{~Hz}, o$-CH-Tipp), 1.64 (d, $6 \mathrm{H}$, ${ }^{3} J_{\mathrm{HH}}=6.6 \mathrm{~Hz}, o$-Me-Tipp), $1.55\left(\mathrm{~d}, 6 \mathrm{H},{ }^{2} J_{\mathrm{HP}}=12.5 \mathrm{~Hz},{ }^{3} J_{\mathrm{HPt}}=26.3 \mathrm{~Hz}, \mathrm{PMe}_{2}\right), 1.44(\mathrm{~d}, 6 \mathrm{H}$, ${ }^{3} J_{\mathrm{HH}}=6.6 \mathrm{~Hz}, p$-Me-Tipp), 1.31 (d, $6 \mathrm{H},{ }^{3} J_{\mathrm{HH}}=6.5 \mathrm{~Hz}, p$-Me-Tipp), $1.29\left(\mathrm{~d}, 6 \mathrm{H},{ }^{3} J_{\mathrm{HH}}=6.5 \mathrm{~Hz}\right.$, $o$-Me-Tipp), $0.99\left(\mathrm{~d}, 6 \mathrm{H},{ }^{3} J_{\mathrm{HH}}=6.4 \mathrm{~Hz}, o\right.$-Me-Tipp), $0.94\left(\mathrm{~d}, 6 \mathrm{H},{ }^{3} J_{\mathrm{HH}}=6.5 \mathrm{~Hz}, o\right.$-Me-Tipp) ppm. ${ }^{13} \mathrm{C}\left\{{ }^{1} \mathrm{H}\right\}$ NMR $\left(96.6 \mathrm{MHz}, 25^{\circ} \mathrm{C}, \mathrm{CD}_{2} \mathrm{Cl}_{2}\right): \delta 163.7$ (s, $p$-Tipp), 151.9 (s, o-Tipp), 151.14 (s, $p$-Tipp'), $148.4\left(\mathrm{~d},{ }^{2} J_{\mathrm{CP}}=21 \mathrm{~Hz}, o-\mathrm{C}_{6} \mathrm{H}_{3}\right), 147.3$ (s, o-Tipp'), $144.9\left(\mathrm{~d},{ }^{2} J_{\mathrm{CP}}=2 \mathrm{~Hz}, o-\mathrm{C}_{6} \mathrm{H}_{3}\right)$, $135.4\left(\mathrm{~d},{ }^{1} J_{\mathrm{CP}}=58 \mathrm{~Hz}, \mathrm{C}_{\mathrm{ipso}}-\mathrm{C}_{6} \mathrm{H}_{3}\right), 133.7\left(\mathrm{~d},{ }^{3} J_{\mathrm{CP}}=3 \mathrm{~Hz}, \mathrm{C}_{\mathrm{ipso}}-\mathrm{Tipp}\right), 133.2\left(\mathrm{~d},{ }^{3} J_{\mathrm{CP}}=7 \mathrm{~Hz}, m-\right.$ $\left.\mathrm{C}_{6} \mathrm{H}_{3}\right), 132.0\left(\mathrm{~d},{ }^{3} J_{\mathrm{CP}}=3 \mathrm{~Hz}, p-\mathrm{C}_{6} \mathrm{H}_{3}\right), 131.0$ (s, $m$ - $\mathrm{C}_{6} \mathrm{H}_{3}$ ), 124.6 (s, $m$-Tipp'), 121.4 (s, $m$-Tipp), 97.4 (d, ${ }^{3} J_{\mathrm{CP}}=3 \mathrm{~Hz}, \mathrm{C}_{\mathrm{ipso}}$-Tipp), 35.9 (s, $p$-CH-Tipp), 35.0 (s, $p$-CH-Tipp), 34.79 (s, o-CHTipp), 31.7 (s, o-CH-Tipp), 26.7 (s, o-Me-Tipp), 25.6 (s, o-Me-Tipp), 25.3 (s, $p$-Me-Tipp), 24.4 (s, p-Me-Tipp), 24.3 (s, o-Me-Tipp), 21.8 (s, o-Me-Tipp), 13.4 (d, ${ }^{1} J_{\mathrm{CP}}=44 \mathrm{~Hz}, \mathrm{PMe}_{2}$ ) ppm. ${ }^{31} \mathrm{P}\left\{{ }^{1} \mathrm{H}\right\}$ NMR $\left(161.9 \mathrm{MHz}, 25{ }^{\circ} \mathrm{C}, \mathrm{CD}_{2} \mathrm{Cl}_{2}\right): \delta 10.6\left(\mathrm{~s},{ }^{1} J_{\mathrm{PPt}}=3226 \mathrm{~Hz}\right) \mathrm{ppm}$.

cis-[PtCl $\left.\left.\mathbf{P}_{2} \mathbf{C O}\right)\left(\mathbf{P M e}_{2} \mathrm{Ar}^{\mathrm{Dipp}_{2}}\right)\right], \mathbf{3 a} \cdot \mathbf{L 5}$. Complex $\left[\mathrm{PtCl}_{2}\left(\mathrm{PMe}_{2} \mathrm{Ar}^{\mathrm{Dipp}_{2}}\right)\right](15 \mathrm{mg}, 0.04 \mathrm{mmol})$ was dissolved in $\mathrm{CD}_{2} \mathrm{Cl}_{2}(0.6 \mathrm{ml})$ under nitrogen. The system was degassed ( 3 freeze-pump-thaw cycles) and charged with $\mathrm{CO}(2 \mathrm{~atm})$ at room temperature. After 4 hours, the sample was analysed by NMR spectroscopy. All volatiles were removed under vacuum affording complex 3a' $\mathbf{L 5}$ as a colourless solid. (Yield: $14 \mathrm{mg}, 90 \%$ ) Anal. Calc. for $\mathrm{C}_{33} \mathrm{H}_{43} \mathrm{Cl}_{2} \mathrm{OPPt}$ : C, 52.7; $\mathrm{H}$, 5.8. Found: C, 52.2; H, 5.7. IR (Nujol): $\bar{v}(\mathrm{CO})=2114 \mathrm{~cm}^{-1} \cdot{ }^{1} \mathrm{H}$ NMR $\left(300 \mathrm{MHz}, 25{ }^{\circ} \mathrm{C}\right.$, $\left.\mathrm{CD}_{2} \mathrm{Cl}_{2}\right): \delta 7.60\left(\mathrm{td}, 1 \mathrm{H},{ }^{3} J_{\mathrm{HH}}=7.8 \mathrm{~Hz},{ }^{5} J_{\mathrm{HP}}=1.7 \mathrm{~Hz}, p-\mathrm{C}_{6} \mathrm{H}_{3}\right), 7.49\left(\mathrm{t}, 2 \mathrm{H},{ }^{3} J_{\mathrm{HH}}=7.7 \mathrm{~Hz}, p-\right.$ Dipp), $7.35\left(\mathrm{dd}, 2 \mathrm{H},{ }^{3} J_{\mathrm{HH}}=7.7 \mathrm{~Hz},{ }^{4} J_{\mathrm{HP}}=3.9 \mathrm{~Hz}, m-\mathrm{C}_{6} \mathrm{H}_{3}\right), 7.32\left(\mathrm{~d}, 4 \mathrm{H},{ }^{3} J_{\mathrm{HH}}=7.7 \mathrm{~Hz}, m-\right.$ Dipp), 2.63 (sept, $\left.4 \mathrm{H},{ }^{3} J_{\mathrm{HH}}=6.6 \mathrm{~Hz}, \mathrm{CH}-\mathrm{Dipp}\right), 1.56\left(\mathrm{~d}, 6 \mathrm{H},{ }^{2} J_{\mathrm{HP}}=12.1 \mathrm{~Hz},{ }^{3} J_{\mathrm{HPt}}=43.2 \mathrm{~Hz}\right.$, $\left.\mathrm{PMe}_{2}\right), 1.39\left(\mathrm{~d}, 12 \mathrm{H},{ }^{3} J_{\mathrm{HH}}=6.6 \mathrm{~Hz}, \mathrm{Me}-\mathrm{Dipp}\right), 1.02\left(\mathrm{~d}, 12 \mathrm{H},{ }^{3} J_{\mathrm{HH}}=6.6 \mathrm{~Hz}\right.$, Me-Dipp) ppm. ${ }^{13} \mathrm{C}\left\{{ }^{1} \mathrm{H}\right\}$ NMR (75.4 MHz, $25{ }^{\circ} \mathrm{C}, \mathrm{CD}_{2} \mathrm{Cl}_{2}$ ): $\delta 184.6$ (s, CO), 147.6 (s, o-Dipp), 145.1 (s, o$\mathrm{C}_{6} \mathrm{H}_{3}$ ), 138.5 (s, $\mathrm{C}_{\text {ipso }}$-Dipp), 134.2 (s, $m-\mathrm{C}_{6} \mathrm{H}_{3}$ ), 130.3 (s, $p$-Dipp), 130.1 (s, $p$ - $\mathrm{C}_{6} \mathrm{H}_{3}$ ), 124.2 (s, m-Dipp), 31.7 (s, CH-Dipp), 26.5 (s, $\mathrm{CH}_{3}$-Dipp), 22.9 (s, Me-Dipp), 19.3 (d, ${ }^{1} J_{\mathrm{CP}}=44 \mathrm{~Hz}$, $\left.\mathrm{PMe}_{2}\right)$ ppm. ${ }^{31} \mathrm{P}\left\{{ }^{1} \mathrm{H}\right\} \mathrm{NMR}\left(121.4 \mathrm{MHz}, 25^{\circ} \mathrm{C}, \mathrm{CD}_{2} \mathrm{Cl}_{2}\right): \delta-16.6\left(\mathrm{~s},{ }^{1} J_{\mathrm{PPt}}=2970 \mathrm{~Hz}\right) \mathrm{ppm}$. 
Computational details. Buried Volume percentages of the phosphines $\left(\% \mathrm{~V}_{\text {Bur }}\right) \mathbf{L}$ were calculated with the SambVca software [23a]. For the sake of comparison the sphere radius was set to $3.5 \AA$, the mesh spacing to 0.05 and the atomic radii were taken from the Bondi radii set [28] scaled by 1.17. The hydrogen atoms were omitted in the calculations. DFT calculations were performed with the Gaussian09 program.[29] Geometry optimizations were carried out in the gas phase with no constrains, using the long range wB97xD functional with empirical dispersion corrections.[30] The use of this functional resulted in better agreement with the $\% \mathrm{~V}_{\text {Bur }}$ obtained from crystallographic data and DFT-optimized geometries than the use of the non dispersion-corrected functional B3LYP and has been shown to perform well in optimizing structures of organometallic complexes with bulky ligands.[31] Lighter atoms were described with the 6-31G(d,p) basis set and the SDD basis + ECP were used for the metal (Ir, Au) atoms. Local minima $\left(\mathrm{V}_{\mathrm{min}}\right)$ of the Molecular Electrostatic Potential (MESP) of some phosphines were obtained by basin analysis of the corresponding 3D grids (cubes) with the Multiwfn software.[32]

Conclusions. A convenient and general method for the preparation of bulky dialkyl terphenyl phosphines $\mathrm{PR}_{2} \mathrm{Ar}$ ', which feature fair air-stability, both in solution and in the solid state, has been described. The dimethyl phosphines $\mathbf{L 1}$ and $\mathbf{L 5}$ have been used as representative examples of this class of ligands for the synthesis of transition metal complexes of $\operatorname{Rh}(\mathrm{I}), \operatorname{Ir}(\mathrm{I})$, and $\operatorname{Pt}(\mathrm{II})$, producing straightforward and selective reactions with common metallic precursors. While in the complexes of the two group 9 metals used here ligands $\mathbf{L 1}$ and $\mathbf{L 5}$ act as monodentate Pdonor ligands, in $\mathrm{Pt}(\mathrm{II})$ complexes two different coordination modes have been recognized for ligand $\mathbf{L 5}$, i.e. the usual $\kappa^{1}-\mathrm{P}$ binding and the bidentate $\kappa^{1}-\mathrm{P}, \eta^{1}$-arene, which involves a weak bonding interaction with one of the flanking aromatic rings of the terphenyl moiety.

\section{Appendix A. Supplementary data}

CCDC 1456781-1456784 and 1456331 contains the supplementary crystallographic data for compounds $\mathbf{L 7}$, L10, $\mathbf{2} \cdot \mathbf{a} \mathbf{L}, \mathbf{2} \cdot \mathbf{a} \cdot \mathbf{L}$, and $3 \cdot \mathbf{L 5}$. These data can be obtained free of charge via http://www.ccdc.cam.ac.uk/conts/retrieving.html, or from the Cambridge Crystallographic Data Centre, 12 Union Road, Cambridge CB2 1EZ, UK; fax: (+44) 1223-336-033; or e-mail: deposit@ccdc.cam.ac.uk.

Acknowledgements. Financial support (FEDER support and Subprogramas Ramón y Cajal and Juan de la Cierva) from Spanish Ministry of Science (Projects CTQ2013-42501-P, CTQ201451912-REDC and CTQ-2014-52769-C3-3-R) and the Junta de Andalucía (Grant FQM-119 and project P09-FQM-4832 and FQM-2126) is gratefully acknowledged. L.O.M. thanks to the Spanish Ministry of Education (grant BES-2011-048035). M.F.E and J.J.M. thank to the Universidad de Sevilla for a research grant. J.C. thanks the EU 7th Framework Program, Marie Skłodowska-Curie actions (COFUND, Grant Agreement no. 267226) and Junta de Andalucía for a Talentia Postdoc Fellowship. The use of computational facilities at the Supercomputing Centre of Galicia (CESGA) is also acknowledged. 


\section{References}

[1] (a) R. H. Crabtree, The Organometallic Chemistry of the Transition Metals, 6th ed., John Wiley \& Sons, Inc, Hoboken, 2014; (b) M. Bochmann, Organometallics and Catalysis. An Introduction. Oxford University Press, Oxford, 2015; (b) J. F. Hartwig, Organotransition Metal Chemistry: From Bonding to Catalysis. Sausalito, 2010; (d) R. H. Crabtree, J. Organomet. Chem., 2005, 690, 5451; (e) C. A. McAuliffe, W. Levason, Phosphine, Arsine and Stibine Complexes of the Transition Elements. Elsevier Scientific Pub. Co., Amsterdam, 1999; (f) L. H. Pignolet, Homogeneous Catalysis with Metal Phosphine Complexes. Ed. Plenum Press, New York, 1983.

[2] C. A. Tolman, Chem. Rev. 1977, 77, 313.

[3] For representative examples of low-coordinate and agostic complexes with phosphine ligands, see: (a) W. Baratta, E. Herdtweck, P. Rigo, Angew. Chem. Int. Ed. 1999, 38, 1629; (b) W. Baratta, S. Stoccoro, A. Doppiu, E. Herdtweck, A. Zucca, P. Rigo, Angew. Chem. Int. Ed. 2003, 42, 105; (c) J. P. Stambuli, M. Bühl, J. F. Hartwig, J. Am. Chem. Soc. 2002, 124, 9346; (d) J. P. Stambuli, C. D. Incarvito, M. Bühl, J. F. Hartwig, J. Am. Chem. Soc. 2004, 126, 1184; (e) E. Fasulo, E. Calimano, J. M. Buchanan T. D. Tilley, Organometallics 2013, 32, 1016; (f) S. D. Pike1, A. L. Thompson, A. G. Algarra, D. C. Apperley, S. A. Macgregor, A. S. Weller, Science 2012, 337, 1648; (g) A. B. Chaplin, R. Tonner, A. S. Weller, Organometallics 2010, 29, 2710; (h) R. Mathialagan, S. Kuppuswamy, A. De Denko, , M. W. Bezpalko, B. M. Foxman, C. M. Thomas, Inorganic Chemistry 2013, 52, 701; (i) D. S. Kuiper, P. T. Wolczanski, E. B. Lobkovsky, T R. Cundari, J. Am. Chem. Soc. 2008, 130, 12931; (j) M. E. van der Boom, M. A. Iron, O. Atasoylu, L. J. W. Shimon, H. Rozenberg, Y. Ben-David, L. Konstantinovski, J. M. L. Martin, D. Milstein, Inorg. Chim.. Acta 2004, 357, 1854; (k) L. Ortega-Moreno, R. Peloso, C. Maya, A. Suárez, E. Carmona, Chem. Commun. 2015, 51, 17008.

[4] S. E. Parker, J.Börgel, T.Ritter, J. Am. Chem. Soc. 2014, 136, 4857.

[5] (a) F. Schaper, S. R. Foley, R, F. Jordan, J. Am. Chem. Soc. 2004, 126, 2114; (b) J. Campos, R. Peloso, E. Carmona, Angew. Chem. Int. Ed. 2012, 51, 8255.

[6] W. H. Bernskoetter, C. K. Schauer, K. I. Goldberg, M. Brookhart, Science 2009, 326, 553.

[7] (a) A. Zapf, A. Ehrentraut, M. Beller, Angew. Chem. Int. Ed. 2000, 39, 4153. (b) W. XiaoFeng, F. Xianjie, W. Lipeng, R. Jackstell, H. Neumann, M. Beller, Acc. Chem. Res., 2014, 47, 1041.

[8] (a) J. P. Wolfe, R. A. Singer, B. H. Yang, S. L. Buchwald, J. Am. Chem. Soc. 1999, 121, 9550; (b) A. Aranyos, D. W. Old, A. Kiyomori, J. P. Wolfe, J. P. Sadighi, S. L. Buchwald, J. Am. Chem. Soc. 1999, 121, 4369; (c) J. P. Wolfe, S. Wagaw, J.-F. Marcoux, S. L. Buchwald, Acc. Chem. Res. 1998, 31, 805; (d) R. Martin and S. L. Buchwald, Acc. Chem. Res. 2008, 41, 1461. (e) T. E. Barder and S. L. Buchwald, J. Am. Chem. Soc. 2007, 129, 5096.

[9] A. F. Littke, G. C. Fu, Angew. Chem. Int. Ed. 2002, 41, 4176.

[10] (a) Q. Shelby, N. Kataoka, G. Mann, J. F. Hartwig, J. Am. Chem. Soc. 2000, 122, 10718; b) G. Mann, C. Incarvito, A. L. Rheingold, J. F. Hartwig, J. Am. Chem. Soc. 1999, 121, 3224; c) J. F. Hartwig, Angew. Chem. Int. Ed. 1998, 37, 2046; (d) J. Hartwig, Acc. Chem. Res. 2008, 41 . 
[11] a) D. S. Surry, S. L. Buchwald, Chem. Sci. 2011, 2, 27; (b) H. Tomori, J. M. Fox, S. L. Buchwald, J. Org. Chem. 2000, 65, 5334; (c) S.Kaye, J. M. Fox, F. A. Hicks, S. L. Buchwald, Adv. Synth. \& Catal., 2001, 343, 789; (d) C. A. Fleckenstein, H. Plenio, Chem. Soc. Rev. 2010, 39, 694.

[12] (a) M. L. Scheuermann, K. A. Grice, M. J. Ruppel, M. Roselló-Merino, W. Kaminsky, K. I. Goldberg, Dalton Trans. 2014, 43, 12018; (b) H. Grützmacher, Angew. Chem. Int. Ed. 2008, 47, 1814; (c) P. Braunstein, F. Naud, Angew. Chem. Int. Ed. 2001, 40, 680; (d) H. Werner, Dalton Trans. 2003, 3829.

[13] (a) R. C. Smith, R. A. Woloszynek, W. Chen, T. Ren, J. D. Protasiewicz, Tetrahedron Lett. 2004, 45, 8327; (b) B. Buster, A. A. Diaz, T. Graham, R. Khan, M. A. Khan, D. R. Powell, R. J. Wehmschulte, Inorg. Chim. Acta 2009, 362, 3465; (c) D. V. Partyka, M. P. Washington, J. B. Updegraff III, X. Chen, C. D. Incarvito, A. L. Rheingold, J. D. Protasiewicz, J. Organomet. Chem. 2009, 694, 1441; (d) J. Campos, L. Ortega-Moreno, S. Conejero, R. Peloso, J. López-Serrano, C. Maya, E. Carmona, Chem. Eur. J. 2015, 21, 8883; (e) M. F. Espada, J. Campos, J. López-Serrano, M. L. Poveda, E. Carmona, Angew. Chem. Int. Ed. 2015, 54, 15379; (f) S. Sasaki, R. Chowdhury, M. Yoshifuji, Tetrahedron Lett. 2004, 45, 9193; (g) S.Sasaki, M.Izawa, M.Yoshifuji, Phosphorus, Sulfur, Silicon Relat. Elem. 2014, 189, 1207; (h) T. Fujihara, K. Semba, J. Terao, Y. Tsuji, Angew. Chem. Int. Ed. 2010, 49, 1472; (i) O. Niyomura, T. Iwasawa, N. Sawada, M. Tokunaga, Y. Obora, Y. Tsuji, Organometallics 2005, 24, 3468; (j) O. Niyomura, M. Tokunaga, Y. Obora, T. Iwasawa, Y. Tsuji, Angew. Chem. Int. Ed. 2003, 42, 1287; (k) A. Kondoh, H. Yorimitsu, K. Oshima, J. Am. Chem. Soc. 2007, 129, 6996; (1) C. Overländer1, J. J. Tirrée, M. Nieger, E. Niecke1, C. Moser, S. Spirk, R. Pietschnig, Appl. Organometal. Chem. 2007, 21, 46.

[14] T. Nguyen, A. D. Sutton, M. Brynda, J. C. Fettinger, G. J. Long, P. P. Power, Science $\mathbf{2 0 0 5}, 310,844$.

[15] (a) M. Carrasco, M. Faust, R. Peloso, A. Rodríguez, J. López-Serrano, E. Álvarez, C. Maya, P. P. Power, E. Carmona, Chem. Commun. 2015, 48, 3954; (b) M. Carrasco, I. Mendoza, M. Faust, J. López-Serrano, R. Peloso, A. Rodríguez, E. Álvarez, C. Maya, P. P. Power, E. Carmona, J. Am. Chem. Soc. 2014, 136, 9173; c) M. Carrasco, I. Mendoza, E. Álvarez, A. Grirrane, C. Maya, R. Peloso, A. Rodríguez, A. Falceto, S. Álvarez, E. Carmona, Chem. Eur. J. 2015, 21, 410.

[16] (a) J. R. VanWazer, C.F. Callis, J. N. Shoolery, R. C. Jones, J. Am. Chem. Soc. 1956, 78, 5715; (b) S. O Grim, W. McFarlane, E. F. Davidoff, J. Org. Chem. 1967, 32, 781; (c) J. Keller, C. Schlierf, C. Nolte, P. Mayer, B. F. Straub, Synthesis 2006, 354; (d) H. Klöcker, S. Roters, A. Hepp, W. Uhl, Dalton Trans. 2015, 44, 12670.

[17] (a) R. J. Angelici, Acc. Chem. Res. 1995, 28, 51; (b) D. F. Shriver, Acc. Chem. Res. 1970, 3,231 .

[18] A. Falceto, E. Carmona, S. Alvarez, Organometallics 2014, 33, 6660.

[19] See for instance: (a) H. A. Zhong, J. A. Labinger, J. E. Bercaw, J. Am. Chem. Soc. 2002, 124, 1378; (b) S. Reinartz, P. S.White, M. Brookhart, J. L. Templeton, Organometallics 2000, 19, 3854; (c) J. C. Thomas, J. C. Peters, Inorg. Chem. 2003, 42, 5055; (d) S. Martínez-Salvador, B. Menjón, J. Forniés, A. Martín, I. Usón, Angew. Chem. Int. Ed. 2010, 49, 4286. 
[20] (a) W. McFarlane, D. S. Rycroft, J. Chem. Soc., Dalton Trans.1973, 2162; (b) D. W. Allen, B. F. Taylor, J. Chem. Soc., Dalton Trans. 1982, 51; (c) A. Suárez, M. A. Méndez-Rojas, A. Pizzano, Organometallics 2002, 21, 4611.

[21] (a) R. P. Pinnell, C. A. Megerle, S. L. Manatt, P. A. Kroon, J. Am. Chem. Soc. 1973, 95, 977; (b) R.D. Kroshefsky, R. Weiss, J.G. Verkade, Inorg. Chem. 1979, 18, 469; (c) C. G. Hrib, F. Ruthe, E. Seppälä, M. Bätcher, C. Druckenbrodt, C. Wismach, P. G. Jones, W.-W. du Mont, V. Lippolis, F. A. Devillanova, M. Bühl, Eur. J. Inorg. Chem. 2006, 1, 88; C. G. Hrib, F. Ruthe, E. Seppälä, M. Bätcher, C. Druckenbrodt, C. Wismach, P. G. Jones, W.-W. du Mont, V. Lippolis, F. A. Devillanova, M. Bühl, Eur. J. Inorg. Chem.2007, 29, 4693; (d) U. Beckmann, D. Süslüyan, P. C. Kunz, Phosphorus, Sulfur, Silicon, Relat. Elem. 2011, 186, 2061.

[22] See for example: (a) L. Perrin, E. Clot, O. Eisenstein, J. Loch, R. H. Crabtree, Inorg. Chem. 2001, 40, 5806; (b) C. H. Suresh, N. Koga, Inorg. Chem. 2002, 41, 1573; (c) D. G. Gusev, Organometallics 2009, 28, 763; (d) O. Diebolt, G. C. Fortman, H. Clavier, A. M. Z. Slawin, E. C. Escudero-Adán, J. Benet-Buchholz, S. P. Nolan, Organometallics 2011, 30, 1668 .

[23] (a) A. Poater, B. Cosenza, A. Correa, S. Giudice, F. Ragone, V. Scarano, L. Cavallo, Eur. J. Inorg. Chem. 2009, 13, 1759; (b) H. Clavier, A. Correa, L. Cavallo, E. C. EscuderoAdán, J. Benet-Buchholz, A. M. Z. Slawin, S. P. Nolan, Eur. J. Inorg. Chem. 2009, 13, 1767; (c) H. Clavier, S. P. Nolan, Chem. Commun 2010, 46, 841.

[24] H. Schumann, G. Cielusek, J. Pickardt, N. Bruncks, J. Organomet. Chem. 1979, 172, 359.

[25] H. C. Clark, L. E. Manzer, J. Organomet. Chem. 1973, 59, 411.

[26] R. H. Crabtree, J. M. Quirk, H. Felkin, T. Fillebeen-Khan, Synthesis and Reactivity in Inorganic and Metal-Organic Chemistry, 1982, 12, 407.

[27] G. Giordano, R. H. Crabtree, Inorg. Synth. 1979, 19, 218.

[28] A. Bondi, J. Phys. Chem. 1964, 68, 441.

[29] Gaussian 09, Revision D. 01, M. J. Frisch, G. W. Trucks, H. B. Schlegel, G. E. Scuseria, M. A. Robb, J. R. Cheeseman, G. Scalmani, V. Barone, B. Mennucci, G. A. Petersson, H. Nakatsuji, M. Caricato, X. Li, H. P. Hratchian, A. F. Izmaylov, J. Bloino, G. Zheng, J. L. Sonnenberg, M. Hada, M. Ehara, K. Toyota, R. Fukuda, J. Hasegawa, M. Ishida, T. Nakajima, Y. Honda, O. Kitao, H. Nakai, T. Vreven, J. A. Montgomery Jr., J. E. Peralta, F. Ogliaro, M. J. Bearpark, J. Heyd, E. N. Brothers, K. N. Kudin, V. N. Staroverov, T. Keith, R. Kobayashi, J. Normand, K. Raghavachari, A. P. Rendell, J. C. Burant, S. S. Iyengar, J. Tomasi, M. Cossi, N. Rega, N. J. Millam, M. Klene, J. E. Knox, J. B. Cross, V. Bakken, C. Adamo, J. Jaramillo, R. Gomperts, R. E. Stratmann, O. Yazyev, A. J. Austin, R. Cammi, C. Pomelli, J. W. Ochterski, R. L. Martin, K. Morokuma, V. G. Zakrzewski, G. A. Voth, P. Salvador, J. J. Dannenberg, S. Dapprich, A. D. Daniels, Ö. Farkas, J. B. Foresman, J. V. Ortiz, J. Cioslowski, D. J. Fox, Gaussian, Inc., Wallingford, CT, USA, 2013.

[30] J.-D. Chai, M. Head-Gordon, Phys. Chem. Chem. Phys. 2008, 10, 6615.

[31] Y. Minenkov, A. Singstad, G. Occhipinti, V. R. Jensen, Dalton Trans. 2012, 41, 5526.

[32] T. Lu, F. Chen, J. Comp. Chem. 2012, 33, 580. 


\section{Graphical abstract.}

A series of bulky phosphine ligands bearing terphenyl substituents ( $\mathrm{PR}_{2} \mathrm{Ar}$ ') has been prepared, characterized, and used for the synthesis of some coordination compounds of $\operatorname{Rh}(\mathrm{I}), \operatorname{Ir}(\mathrm{I})$, and $\mathrm{Pt}(\mathrm{II})$. While the expected $\kappa^{1}-\mathrm{P}$ coordination mode is found for rhodium and iridium species, the dichloride phosphine $\mathrm{Pt}(\mathrm{II})$ derivative obtained by reaction of $\mathrm{PtCl}_{2}$ with $\mathrm{PMe}_{2} \mathrm{Ar}^{\mathrm{Dipp}_{2}}$ exhibits a bidentate $\kappa^{1}-\mathrm{P}, \eta^{1}$-arene coordination mode.

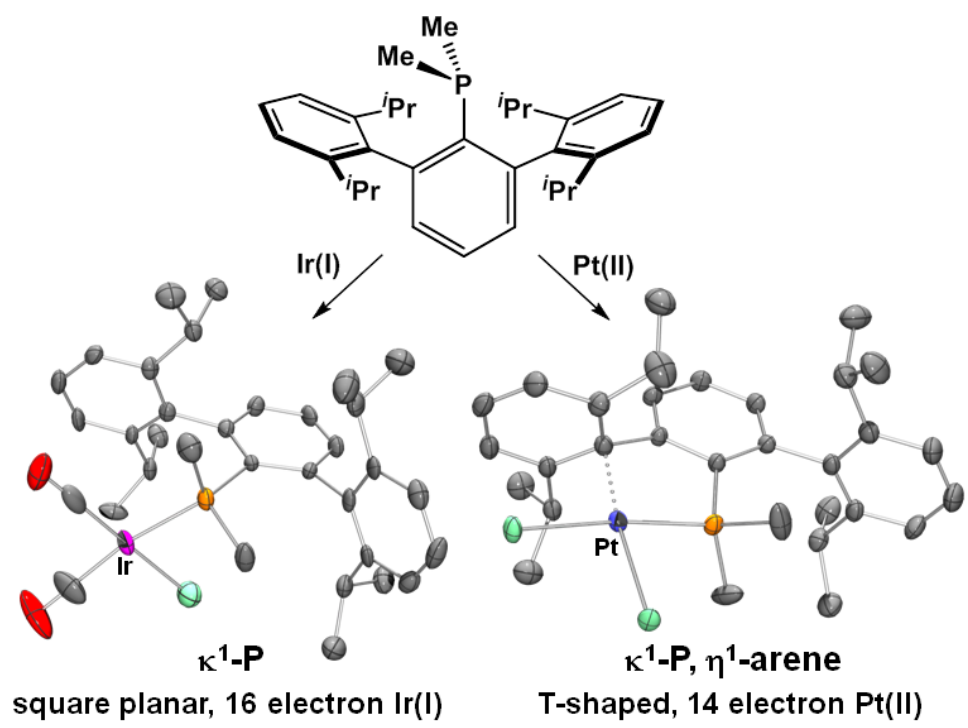

